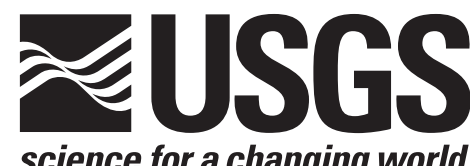

science for a changing world

\title{
Preliminary Model of Porphyry Copper Deposits
}

Open-File Report 2008-1321

U.S. Department of the Interior

U.S. Geological Survey 



\section{Preliminary Model of Porphyry Copper Deposits}

By Byron R. Berger, Robert A. Ayuso, Jeffrey C. Wynn, and Robert R. Seal

Open-File Report 2008-1321 


\title{
U.S. Department of the Interior DIRK KEMPTHORNE, Secretary
}

\author{
U.S. Geological Survey \\ Mark D. Myers, Director
}

U.S. Geological Survey, Reston, Virginia: 2008

For product and ordering information:

World Wide Web: http://www.usgs.gov/pubprod

Telephone: 1-888-ASK-USGS

For more information on the USGS —-the Federal source for science about the Earth, its natural and living resources, natural hazards, and the environment:

World Wide Web: http://www.usgs.gov

Telephone: 1-888-ASK-USGS

Any use of trade, product, or firm names is for descriptive purposes only and does not imply endorsement by the U.S. Government.

Although this report is in the public domain, permission must be secured from the individual copyright owners to reproduce any copyrighted materials contained within this report.

Suggested citation:

Berger, B.R., Ayuso, R.A., Wynn, J.C., and Seal, R.R., 2008, Preliminary model of porphyry copper deposits: U.S. Geological Survey Open-File Report 2008-1321, 55 p. 


\section{Contents}

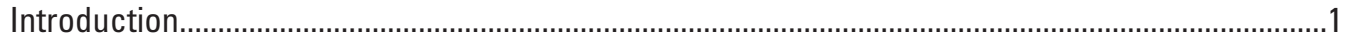

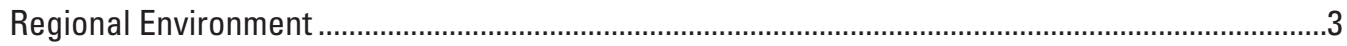

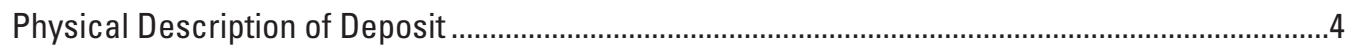

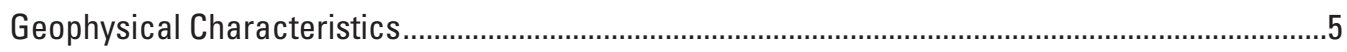

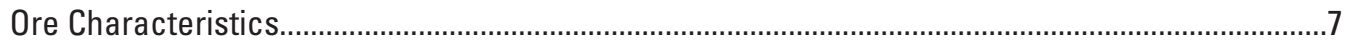

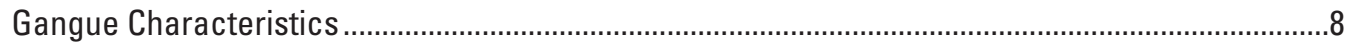

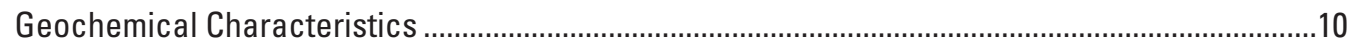

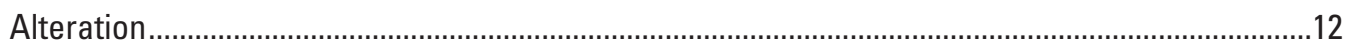

Petrology of Associated Igneous Rocks ..........................................................................................14

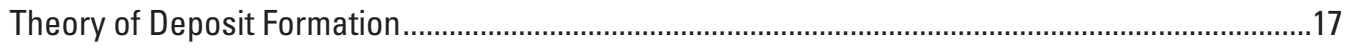

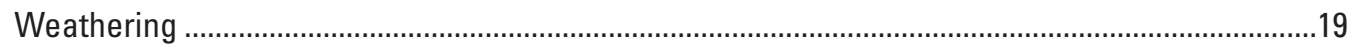

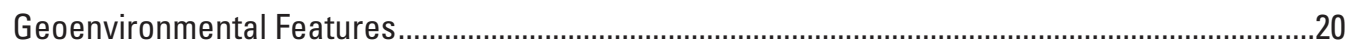

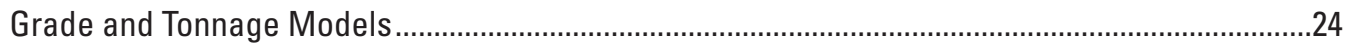

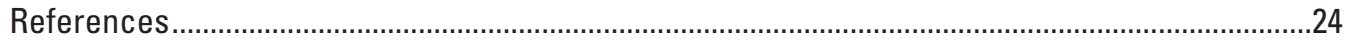

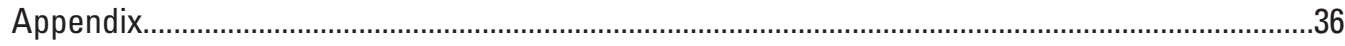

\section{Figures}

1. Cross section of a porphyry copper deposit showing idealized alteration zoning (after Lowell and Guilbert, 1970).

\section{Tables}

1. Intrusive rock compositions associated with selected porphyry copper deposits.........37

2. Major and minor axes of extent of altered rock, orebodies, and sulfide-bearing rock in kilometers together with the total area of altered rock, ore, and sulfide-bearing area, in square kilometers for selected deposits, worldwide.

3. Sulfide, supergene, and alteration mineralogy in a representative selection of porphyry-style copper deposits, worldwide

4. Alteration-mineral assemblages in the Copper Mountain (British Columbia, Canada) and El Teniente (Chile) porphyry copper deposits 



\title{
Preliminary Model of Porphyry Copper Deposits
}

\author{
Byron R. Berger, Robert A. Ayuso, Jeff C. Wynn, and Robert R. Seal
}

\section{Introduction}

Porphyry copper deposits result from the complex interactions and feedbacks of many processes. Owing to the complexity, a succinct definition that includes the essential attributes of this deposit class is elusive. Consequently, this descriptive model uses a working definition of a porphyry copper deposit. A porphyry copper deposit is defined as follows:

1. One wherein copper-bearing sulfides are localized in a network of fracture-controlled stockwork veinlets and as disseminated grains in the adjacent altered rock matrix;

2. Alteration and ore mineralization at $1-4-\mathrm{km}$ depth are genetically related to magma reservoirs emplaced into the shallow crust (6-8+ km), predominantly intermediate to silicic in composition, in magmatic arcs above subduction zones;

3. Intrusive rock complexes that are emplaced immediately before porphyry deposit formation and that host the deposits are predominantly in the form of upright-vertical cylindrical stocks and(or) complexes of dikes;

4. Zones of phyllic-argillic and marginal propylitic alteration overlap or surround a potassic alteration assemblage; and,

5. Copper may also be introduced during overprinting phyllic-argillic alteration events.

The general attributes of porphyry copper deposits are summarized below.

\section{Brief Description}

In hypogene parts of porphyry copper deposits, the copper occurs predominantly in chalcopyrite; other important copper ore minerals may include bornite and enargite. Ore minerals occur as disseminations and in stockworks of veins in hydrothermally altered, shallow intrusive complexes, often porphyritic, and in adjacent country rocks. This model covers all porphyrystyle copper deposits and includes copper-molybdenum, copper-molybdenum-gold, and copper-gold subtypes that are sometimes distinguished by economic geologists (for example, Sillitoe, 2000). A brief discussion of the porphyry copper subtypes is in the Appendix.

\section{Associated Deposit Types}

A variety of deposit types are spatially, if not genetically, related to porphyry copper mineralization, including skarns, polymetallic veins and replacements, and epithermal veins. Copper skarn deposits occur near many porphyry copper host intrusions that intruded carbonate-bearing units (Einaudi and others, 1981), and skarn mineral zoning patterns may be useful in the targeting of a potentially associated porphyry copper deposit (Meinert and others, 2005). Typically, the garnet/pyroxene ratio 
increases toward the causative skarn-forming pluton with the distal pyroxene zones containing more iron- and manganese-rich pyroxenes than proximal zones (Meinert and others, 2005). In some districts (for example, Christmas, Arizona, and Battle Mountain, Nevada), more copper is recovered from calc-silicate rocks than from the associated intrusive rocks.

Polymetallic replacement deposits occur in carbonate-bearing units peripheral to porphyry-style mineralization. At Bingham, Utah (Babcock and others, 1995), and Bisbee, Arizona (Bryant and Metz, 1966), polymetallic replacement deposits surround the intrusive complexes with offshoots appearing to radiate outward from the stocks. Vein deposits occur peripheral to many porphyry copper deposits (for example, Bingham, Utah), as well as crosscutting porphyry-style mineralization (for example, Valea Morii, Romania).

\section{Primary Commodities}

Copper is the primary commodity of economic interest in most porphyry copper deposits, although some deposits with low to very low copper grades are mined principally for their gold (for example, Çopler, Turkey) and(or) molybdenum (for example, Sierrita, Arizona; Continental [Butte], Montana) resources.

\section{By-Product Commodities}

Molybdenum, gold, and silver are the economically most important by-products.

\section{Trace Constituents}

Rhenium and platinum-group metals are recovered from some deposits. Augé and others (2005) reported the occurrence of platinum-group-metal-bearing tellurides and arsenides in an assemblage of magnetite, chalcopyrite, and bornite in the porphyry deposit at Elatsite, Bulgaria. Tin has been reported from some deposits. Jambor and Owens (1987) found complex tin-bearing sulfide minerals in late-stage veins in the Maggie deposit in British Columbia (Canada), together with a polymetallic assemblage of copper-, zinc-, lead-, and silver-bearing sulfide minerals.

\section{Example Deposits}

There are many important deposits, worldwide (compare Singer and others, 2008). Examples of well-studied giant porphyry copper deposits include El Teniente and El Salvador in Chile, Bajo de la Alumbrera in Argentina, Grasberg in Indonesia, and Bingham in the United States. 


\section{Regional Environment}

\section{Geotectonic Environment}

Porphyry copper deposits form in continental magmatic arcs along convergent plate-margin boundaries or in island-arc environments. The deposits are associated with subduction-related volcanic centers, although in some examples, they are thought to be associated with postcollisional volcanism. Permissive magmatic-arc environments may be transpressional or transtensional.

Deformation of magmatic arcs can be exceedingly complex owing to the large variety of mechanisms by which strains can be partitioned in the postmagmatic geologic history of a terrane. Despite the complexity, however, Hindle and Kley (2002) found in the Andes that different scales of analysis elucidate different tectonic effects. For example, near the surface, multitudes of small displacement structures may be typical; yet, at depth, the structures merge and transfer their displacements to large basement faults. Thus, the localization of volcanic centers and their spatial histories may reflect local manifestations of tectonic strains, while chains of volcanic centers may reflect more regional-scale strains. Such issues are important when trying to interpret the localization of porphyry copper deposits within extensive magmatic arcs.

\section{Temporal (Secular) Relations}

Owing to the shallow depths of deposit formation (1-4 km), preserved deposits are predominantly Mesozoic and Cenozoic, although there are important older examples. In their worldwide database of porphyry copper deposits, Singer and others (2008) tabulated known or inferred ages for each tabulated deposit.

\section{Relations to Structures}

It is generally accepted that porphyry copper deposits are structurally controlled, but opinions vary as to the relative importance of regional compared to local fault systems. Titley (1993) concluded that the importance regional structures have in the localization of deposits is an unresolved issue. Also evaluating the importance of regional-scale structures, Sillitoe (1993) concluded that, at many deposits, there is a lack of evidence that faults of "regional dimensions" control the localization of deposits. More recently, Tosdal and Richards (2001) and Sillitoe and Perelló (2005) also concluded that there are no unique structural environments within which deposits form.

Deposits form in areas of shallow magmatism within subduction-related tectonic environments. The study of a number of deposits (Berger and Drew, 1998; Drew, 2006) shows that there are systematic structural relations that economically viable deposits hold in common. Deposits only form when and where structurally controlled permeability is tightly constrained by regional structure. For example, a common location for deposits is along fault zones where strike-slip displacement is interrupted and transferred onto sets of normal to normal-oblique faults that define an extensional stepover to another, parallel strike-slip fault (also called a pull-apart structure). Fluid flow and magmatism are concentrated into the hinge zones (R. Goldfarb, written commun., 2008), such as at the well-studied Grasberg deposit, Indonesia (for example, Sapiie and Cloos, 2004). 


\section{Relations to Igneous Rocks}

Porphyry copper deposits result from the condensation of supercritical fluids derived from a crystallizing magma reservoir or set of linked reservoirs in the shallow crust; most likely, the source reservoirs are at depths of 8-10 km or more. A recent study of the Questa porphyry molybdenum deposit in New Mexico suggests that the ore fluid was probably derived from a source reservoir or reservoirs as deep as the middle crust (Klemm and others, 2008). Eight- to 15- or 20-kilometer-deep supercritical ore fluids separate and rise from their sources to form deposits in shallow subvolcanic intrusive complexes at 1-4 km depth. These shallow subvolcanic complexes are typically made up of multiple intrusions of varying composition, as summarized in the "Petrology of Associated Igneous Rocks" section.

For porphyry copper deposits in general, the compositions of the shallow intrusions that host porphyry copper deposits indicate that the deep melt reservoirs from which both the shallow intrusions and the ore fluids were derived may be compositionally calc-alkaline, alkali-calcic, or alkaline (Seedorff and others, 2005). Representative examples of the rock types found in porphyry copper deposits are listed in table 1.

\section{Relations to Sedimentary Rocks}

Volcaniclastic rocks are common in many districts, but any sedimentary rock may be spatially associated with a porphyry copper deposit. Where carbonate rocks or carbonate-bearing units are host rocks, replacement skarn assemblages are found.

\section{Relations to Metamorphic Rocks}

Metamorphism does not contribute to the formation and localization of porphyry copper deposits, although metamorphosed rocks are host rocks in some districts.

\section{Physical Description of Deposit}

\section{Dimensions in Plan View}

Singer and others (2008) tabulated the dimensions, including the area of hydrothermal alteration, orebodies, and sulfidebearing rock, for selected deposits worldwide. These data are shown in table 2. The median size of the longest axis of alteration surrounding a porphyry copper deposit is $4-5 \mathrm{~km}$, while the median size area of alteration is $7-8 \mathrm{~km}^{2}$ (table 2).

\section{Vertical Extent}

The vertical extent of ore is dependent upon the lower copper cutoff grade, which will vary with the price of copper and local mining costs. At Dos Pobres, Arizona, from the top of the orebody to the 0.2 percent copper cutoff at its deepest points is approximately 1-1.2 km (Langton and Williams, 1982). At Sierrita, Arizona, from ore exposed at the surface to the base of "low 
grade" copper mineralization is from approximately 0.8-1.1 km (West and Aiken, 1982). At Bingham, Utah, the greatest vertical extent of copper ore is approximately $1.4 \mathrm{~km}$ (Babcock and others, 1995).

\section{Form/Shape}

Deposits are typically semicircular to elliptical in plan view. Areal dimensions for ore and alteration (table 2) were calculated assuming an elliptical shape for each deposit unless published information indicated otherwise. Refer to Singer and others (2008) for more information.

In cross section, ore-grade material in a deposit typically has the shape of an inverted cone with the altered, but low-grade, interior of the cone referred to as the "barren" core. In some deposits, for example Grasberg, Indonesia, the low-grade core is a late-stage intrusion (MacDonald and Arnold, 1994).

\section{Host Rocks}

Most porphyry copper deposits are associated with shallow intermediate to silicic intrusive complexes composed of small plutons and dikes; some are associated wholly with dikes. Representative host-rock types are listed in table 1. Ore is sometimes hosted in volcanic and sedimentary rocks into which the shallow intrusive rocks were emplaced.

\section{Structural Setting(s) and Controls}

There is no broad consensus on the structural localization of porphyry copper deposits at regional scale (for example, Sillitoe, 1993; Titley, 1993). Within deposits, stockwork fracture networks are prominent ore-controlling structures in porphyry-style deposits, and studies such as that by Heidrick and Titley (1982) have shown the fractures to have preferred orientations within a given deposit.

\section{Geophysical Characteristics}

\section{Regional}

Porphyry copper districts commonly coincide with magnetic anomalies transverse to the predominant structural grain whose gradients represent large regional faults such as near deposits in northern Chile (Behn and others, 2001; Gow and Walshe, 2005), central Iran (Shahabpour, 1999), and New Guinea (Gow and Walshe, 2005).

Local

Porphyry copper deposits often, but not always, appear as magnetic highs, with alteration halos usually manifested as annular (donut-shaped) or open-ring peripheral magnetic lows (Heithersay and Walshe, 1995; Ford and others, 2007). Typically, there is significant variability in magnetic susceptibility throughout the altered rock owing to the nonhomogeneity of phyllic 
alteration-related magnetite destruction and late-stage magnetite formation (Gettings, 2005). Porphyry copper deposits almost always appear as moderate gravity lows, especially if the host rock is igneous or metamorphic (Oldenburg and others, 1997). Low, near-surface seismic velocities in porphyry systems correlate well with the phases of a batholith hosting the mineralization, which structurally lie in faulted and brecciated regions (Roy and Clowes, 2000). Mineralized rock almost always has lower resistivity than barren parts of the host stock and surrounding rocks due to the presence of clay minerals and stockwork veins with higher water content, owing to increased fracture permeability.

Induced polarization (IP) anomalies are generally, but not always, a diagnostic indicator of economic mineralization. The IP anomalies correlate with both mineralization and alteration-related magnetic lows; however, IP anomalies often indicate the most abundant pyrite zones in altered rocks rather than areas of less-IP-reactive clay minerals, chalcopyrite, and bornite. Spectral IP has been used to classify different alteration zones and to distinguish noneconomic sulfides such as pyrite from chalcopyrite and bornite (Zonge and Wynn, 1975; Zonge and others, 2005). Resistivity and IP anomaly strengths correlate inversely with resistivity of the host rock and the thickness of any cover. Radiometric methods will show the potassic alteration if significant potassically altered parts of the system are exposed (Sinclair, 1995). Likewise, bands 4/5 and 7/9 of ASTER satellite imagery and radiometric spectrometers have been used to map potassium and thorium anomalies representative of alteration halos surrounding deposits (Rowan and others, 2003; Ranjbar and others, 2004; Shayestehfar and others, 2005).

Potassic, phyllic, argillic, and propylitic alteration halos of porphyry copper deposits contain distinct spectral absorption features that can be mapped using multispectral and hyperspectral remote sensing data (Berger and others, 2003; Mars and Rowan, 2006; Rowan and others, 2006). Argillic minerals alunite, and kaolinite have doublet absorption features at 2.17 and $2.20 \mu \mathrm{m}$, and pyrophyllite has a narrow, intense absorption feature at $2.17 \mu \mathrm{m}$ (Salisbury and others, 1983, and Clark and others, 2007). Phyllically altered rocks typically contain sericite, which is composed of muscovite that has a strong $2.20-\mu \mathrm{m}$ absorption feature. Propylitically altered rocks contain varying amounts of chlorite, calcite, and epidote, which have 2.32-2.35- $\mu \mathrm{m}$ absorption features (Salisbury and others, 1983; Rowan and others, 2006; Clark and others, 2007). In the thermal infrared region, quartz and hydrous silica contain emission minima near 8.40 and $8.95 \mu \mathrm{m}$, which are typically found in potassic-altered cores that have been enriched in silica (Rowan and others, 2006).

Advanced Spaceborne Thermal Emission and Reflection Radiometer (ASTER) multispectral data have been used to regionally map porphyry copper deposits in Iran, Afghanistan, and Kazakhstan (Mars and Rowan, 2006). Argillically altered rocks (containing alunite and kaolinite) of porphyry copper systems were regionally mapped using ASTER band ratios b4/b5, b5/ b6, and b6/b7 combined in a logical operator algorithm (Mars and Rowan, 2006). Using the same band ratios and methods, but different band thresholds, muscovite-rich, phyllic-altered rocks have also been regionally mapped (Mars and Rowan, 2006). In regional studies, porphyry copper deposits that are not structurally deformed are typically associated with semicircular to elliptical patterns of argillically and phyllically altered rocks (Mars and Rowan, 2006). Siliceous, phyllic, argillic, and propylitic rocks have been mapped using ASTER data and a matched filtering algorithm incorporating image spectra at the Reko Diq porphyry copper deposit in Pakistan (Rowan and others, 2006). Siliceous rocks were also mapped at Reko Diq, Pakistan, using ASTER band ratio 14/12 (Rowan and others, 2006).

The hyperspectral Airborne Visible Infrared Imaging Spectrometer (AVIRIS) has also been used to map altered rocks associated with porphyry copper deposits at the Red Mountain and Sunnyside deposits in the Northern Patagonia Mountains of 
Arizona (Green and others, 1998; Berger and others, 2003). Alunite, kaolinite, pyrophyllite, and muscovite were mapped at the Red Mountain and Sunnyside deposits using Tetracorder, a spectral feature-fitting algorithm (Clark and others, 2003).

\title{
Ore Characteristics
}

\author{
Mineralogy
}

The ore mineralogy of selected porphyry copper deposits is given in table 3 . The principal hypogene, copper-bearing sulfide mineral is chalcopyrite, although substantial amounts of copper may occur as bornite, enargite, and chalcocite. By-product minerals frequently include molybdenite and native gold. Other associated minerals may include sphalerite, galena, tetrahedrite, and gold tellurides.

\section{Mineral Assemblages}

Copper-ore mineral assemblages are a function of the chemical composition of the fluid phase and the pressure and temperature conditions affecting the fluid. Thus, specific mineral associations may vary in a deposit as a function of space and time as the composition of the hydrothermal fluid changes. In primary, unoxidized or not supergene-enriched ores, the most common ore-sulfide assemblage is chalcopyrite \pm bornite, with pyrite and minor amounts of molybdenite. In some deposits, there is an advanced argillic alteration that overprints near-neutral $\mathrm{pH}$ alteration and mineralization. For example, at Rosia Poieni, Romania, the advanced argillic ore-sulfide assemblage is pyrite + enargite + marcasite + chalcocite (Milu and others, 2004). In supergene enriched ores, a typical assemblage might be chalcocite + covellite \pm bornite (Schwartz, 1966). In oxide ores, a typical assemblage might include malachite + azurite + cuprite + chrysocolla, with minor amounts of other minerals (for example, carbonates, sulfates, phosphates, and silicates) (Schwartz, 1966).

\section{Paragenesis}

For deposits that have been studied in detail, sulfide-ore mineral paragenesis varies widely within and between deposits. Bagdad, Arizona, illustrates the complexity that is encountered in a porphyry-style deposit, although the specifics of the Bagdad paragenesis should not be construed as a model for all porphyry copper deposits. Barra and others (2003) studied the sulfide mineralogy at Bagdad. They defined "early mineralization" wherein molybdenite was the sole ore sulfide mineral present. Subsequent "hypogene" mineralization paragenesis included assemblages of molybdenite, pyrite + chalcopyrite, molybdenite, pyrite, chalcopyrite + pyrite, molybdenite + pyrite + chalcopyrite, and sphalerite + galena + tetrahedrite \pm silver. This paragenetic sequence differs from that published by Anderson and others (1955) who did not observe early-stage molybdenite mineralization but did observe the later molybdenite + pyrite-bearing veins crosscutting chalcopyrite + pyrite veins. In many cases, the paragenetic sequence reported may be reflective to the date of a study, considering the extent of mining at that date. At Batu Hijau, Indonesia, Arif and Baker (2004) looked in detail at the copper sulfide paragenesis, particularly with respect to its association with gold. The early-stage veins contain bornite, digenite, and chalcocite wherein digenite occurs as exsolution lamellae 
in the bornite and chalcocite rims the bornite-digenite grains. Crosscutting veins contain chalcopyrite \pm bornite. Arif and Baker (2004) also note evidence that chalcopyrite \pm pyrite replaced some early-stage bornite + digenite \pm chalcocite. Cubanite has been reported from some porphyry copper deposits (table 3). Ramdohr (1980) suggests that such occurrences, for example the digenite at Batu Hijau, are due to exsolution from an originally higher temperature solid solution.

\section{Zoning Patterns}

The zoning of sulfide minerals, particularly with respect to pyrite content, has been documented in many deposits. Nielsen (1968) found that the pyrite content at Santa Rita, New Mexico, increases from irregular zones with $<1$ wt (weight) percent pyrite in the central part of the deposit, through a surrounding zone with 1-4 wt percent pyrite to an outer zone with $>4 \mathrm{wt}$

percent. The greatest chalcopyrite content, $>0.4 \mathrm{wt}$ percent chalcopyrite, tended to be in the zone with intermediate amounts of pyrite. Inward from this higher chalcopyrite zone, the chalcopyrite decreased to $<0.1$ wt percent, whereas outward from the higher grade zone it ranged between 0.1 wt percent and 0.4 wt percent. At Bingham, Utah, John (1978) defined five overlapping, but concentric, zones as follows from the center outward: deep low-grade core $(<0.5 \mathrm{wt}$ percent sulfides including pyrite, chalcopyrite, bornite, and molybdenite), molybdenite, bornite + chalcopyrite, chalcopyrite + pyrite, pyrite, and galena + sphalerite As at Santa Rita, at Bingham the inner zone has little pyrite, the copper ores contain 1-2 wt percent pyrite, and surrounding the copper ore the pyrite content can exceed 4 wt percent.

\section{Textures and Structures}

Ore minerals occur disseminated through the altered rock matrix and in discrete veins filling fractures. At Bagdad, Anderson and others (1955) observed that some disseminated sulfides form linear chains of minerals that are suggestive that even disseminated mineralization was localized by fractures, now annealed. In the disseminated ores, individual sulfide grains may exceed $1 \mathrm{~mm}$ in longest dimension, but most are smaller (Anderson and others, 1955). Ore minerals in discrete veins may occur as dispersed grains or in clots and occur also in alteration selvages to the veins.

\section{Grain Size}

Typically, the principal copper sulfides and molybdenite consist of millimeter-scale grains, but may be as large as $1-2 \mathrm{~cm}$ in diameter and, rarely, pegmatitic (larger than $2 \mathrm{~cm}$ ).

\section{Gangue Characteristics}

\section{Mineralogy}

In porphyry copper deposits, copper ores include disseminated and vein-form styles of mineralization. Thus, gangue material reflects many or all of the sulfide minerals in the "Ore Characteristics" section and the "Alteration" section. The information 
in these sections is summarized in table 2. The most abundant gangue sulfide is pyrite. Other gangue sulfides found, but generally in small quantities, include pyrrhotite, sphalerite, tennantite, and galena. The most abundant gangue silicate and oxide minerals are quartz, K-feldspar, biotite, muscovite (sericite), magnetite, chlorite, anhydrite, and epidote. Other commonly occurring gangue minerals are rutile, apatite, and titanite.

\section{Mineral Assemblages}

The mineral assemblages are the same as in the "Ore Characteristics" section and the "Alteration" section. As noted by Schwartz (1947) from the study of 12 deposits in North America (table 4), the hydrothermal alteration and mineralization in porphyry copper deposits is complex and variable both within individual deposits and between different deposits.

\section{Paragenesis}

The specifics of gangue paragenesis vary within and between deposits. Some examples are given in the "Ore Characteristics" section and the "Alteration" section.

\section{Zoning Patterns}

Zoning patterns follow mineralization and alteration zoning patterns as discussed in the "Ore Characteristics" section and the "Alteration" section. Titley (1982) reports that different alteration mineral assemblages develop sequentially and the veingangue assemblage zoning reflects this paragenesis.

\section{Textures and Structures}

Pervasive alteration results in the partial to complete replacement of the primary host-rock minerals. Phenocrysts in porphyritic rocks are typically pseudomorphed, with the individual alteration grains replacing the phenocrysts consisting of an agglomeration of small crystals that take on the form of the phenocryst. Ragged-appearing biotite commonly occurs in this manner. Linear arrays of gangue minerals, such as pyrite or potassium feldspar, may be present with no apparent fracture control. Only wispy veinlets are generally found in pervasively altered rock.

Stockworks of veins, predominantly quartz, are a common form of gangue. Veins are often classified according to crosscutting relations in conjunction with form (for example, A, B, and D veins of Gustafson and Hunt, 1975). For example, early stage veins in many porphyry copper deposits have irregular or wavy margins, typically lack banding, and have a granular texture. Later stage, crosscutting veins typically have sharp boundaries, and banding is more common.

\section{Grain Size}

Grain sizes vary within and between deposits; variation is from microscopic to millimeter to centimeter scale. 


\section{Geochemical Characteristics}

\section{Trace Elements and Element Associations}

Deposit-scale studies of trace elements have shown that copper, molybdenum, gold, silver, barium, lead, zinc, arsenic, antimony, and tellurium make up suites related to alteration zoning within deposits (for example, Beus and Grigorian, 1977; Chaffee, 1982, 1992, 1994). The principal associations are copper-molybdenum-gold \pm silver-arsenic and barium-zinc-leadantimony-silver-arsenic-tellurium \pm bismuth.

Olade and Fletcher (1976) found that sulfide iron and copper concentrations, as determined from selective leaches, are highest in ore-bearing rock. Total sulfur anomalies broadly outline mineralization and are often highest in pyritic propylitic alteration zones. Similar results were obtained by Chaffee (1982).

Gold is an important by-product in many porphyry copper deposits, but the details of its occurrence are not broadly understood (for example, Arif and Baker, 2004). A comprehensive study of gold was conducted at Batu Hijau, Indonesia, by Arif and Baker (2004). They found gold in quartz veins, attached to sulfide grains, and as free gold along silicate grain boundaries. Gold is predominantly found in association with bornite; and, in bornite-rich ores, the gold is within the sulfide mineral structure and present as small grains of native gold. In chalcopyrite-rich ores, the gold occurs primarily as small grains within the copper sulfide.

\section{Zoning Patterns}

A summary of zoning studies was published by Govett (1983). Copper, molybdenum, gold, and tin are most anomalous within the ore zones. Although silver and arsenic are also anomalous within ore zones, they also occur with barium, zinc, lead, and antimony in immediately overlying subeconomic, altered rock (Beus and Grigorian, 1977). Govett's (1983) summary shows that silver, zinc, lead, antimony, arsenic, tellurium, and bismuth are anomalous lateral to ore zones. At Kalamazoo, Arizona, Chaffee (1982) found that tellurium was most anomalous above ore and that zinc and lead form negative anomalies immediately above and within ore.

\section{Fluid-Inclusion Thermometry and Geochemistry}

A wide range of fluid-inclusion homogenization temperatures has been obtained from porphyry copper deposits. Klemm and others (2007) reported homogenization temperatures from about $550^{\circ} \mathrm{C}$ to about $250^{\circ} \mathrm{C}$, with single measurements within individual assemblages varying by as much as about $100^{\circ} \mathrm{C}$ for samples from El Teniente, Chile. When binned in $10^{\circ} \mathrm{C}$ intervals, the median reported homogenization temperature range in the El Teniente data is $380^{\circ}-390^{\circ} \mathrm{C}$. At Bajo de la Alumbrera, Argentina, Ulrich and others (2001) reported homogenization temperatures varying from about $770^{\circ} \mathrm{C}$ to about $200^{\circ} \mathrm{C}$, with single measurements within individual assemblages varying by as much as $100^{\circ} \mathrm{C}$ or more. When binned in $10^{\circ} \mathrm{C}$ intervals, the median reported homogenization temperature range (excluding extrapolated temperatures) in the Bajo de la Alumbrera data is $470^{\circ}-480^{\circ} \mathrm{C}$ 
Bodnar (1995) summarized evidence that the source of metals in porphyry deposits is magmatic and described fluid-inclusion evidence. Bodnar and Cline (1991) and Bodnar (1995) described magmatic fluid inclusions as high-salinity and halitebearing, which homogenize at relatively high temperature (greater than $500^{\circ}-600^{\circ} \mathrm{C}$ ). Magmatic fluid inclusions are found in quartz in early veins and show a range of characteristics that reflect the different depths at which the inclusions were trapped. For example, the deeper levels of a porphyry system are represented at the Butte, Montana, porphyry copper-molybdenum deposit (Montana) (Roberts, 1975; Rusk and others, 2008), where the chalcopyrite-bearing inclusions in deep veins have moderate to low salinity (2-5 wt percent sodium chloride equiv), 2-8 mol-percent carbon dioxide, and have moderate homogenization temperatures $\left(575^{\circ}-650^{\circ} \mathrm{C}\right)$ and pressures equivalent to about 6-9-km depth (Rusk and others, 2008). In shallower systems, as in the Red Mountain, Arizona, porphyry copper deposit, the magmatic fluids formed vapor-rich inclusions that trapped a low-density, low-salinity fluid that exsolved directly from the magma (Bodnar, 1995). Hedenquist and Richards (1998, and references therein) explained the coexistence of hypersaline-liquid-rich and vapor-rich fluid inclusions by the unmixing of an originally homogeneous aqueous fluid that exsolved from magma at pressures of 1-1.5 kbar. The magmatic fluid is transported to relatively shallow crustal levels, and ore deposition takes place at ambient pressures of about 0.5 kbar where the fluid intersects its solvus, producing immiscible saline liquid and vapor phases.

In the magma reservoir from which the hydrothermal fluids are exsolved, decompression and fractional crystallization of silicic magma triggers separation of an aqueous phase and bubbles in the residual melt (Burnham, 1979). The function of fluidphase separation in ore-metal fractionation and mineral precipitation resulting from the wide density variations and degree of miscibility of saline fluids between surface and magmatic conditions have been the focus of studies by Heinrich (2007). Evidence for volatile separation includes the presence of miarolitic cavities (Candela and Blevin, 1995) and pods of saccharoidal quartz connected by anastomosing zones of graphic quartz-alkali feldspar intergrowths and ragged biotite (with lesser apatite and magnetite) (Harris and others, 2004). In the Western United States, crystals of copper and molybdenum sulfides have been found in the miarolitic cavities (for example, Wilson, 1975). Gustafson and Hunt (1975) recognized several intrusive stages related to the El Salvador, Chile, porphyry copper deposit, described fluids associated with different generations of veins, and attributed the early-alteration-mineralization stage to magmatic fluids. Dilles (1987) studied the evolution of ore fluids in the Yerington, Nevada, porphyry copper district and concluded that an aqueous fluid, rich in sodium, chloride, potassium, iron, and sulfur species, causes copper and molybdenum sulfide mineralization. Harris and others (2003, 2004) documented the presence of interconnected miarolitic cavities (and associated quartz segregations) and investigated silicate-melt inclusions and coexisting aqueous phases captured in primary inclusions at the Bajo de la Alumbrera, Argentina, porphyry copper-gold deposit. Such textural and silicate-melt inclusion data document volatile-phase separation and link magmatic processes to hydrothermal alteration.

The compositional evolution of the fluids had been constrained by documentation of petrography, microthermometry, and LA-ICP-MS analysis of fluid inclusions (for example, Ulrich and others, 2001; Klemm and others, 2007). Scanning electron microscope cathodoluminescence studies have shown the successive generations of fluid inclusions in texturally complex quartz veinlets during the main stages of metal transfer in the porphyry copper-gold-molybdenum deposit at Bingham (Landtwing and others, 2005). At Bingham, early quartz veins are brightly luminescent and crystallized before the copper-iron sulfides precipitated in these veins. The LA-ICP-MS analyses also show that fluids trapped before and after precipitation of the copper-iron sulfides are largely similar in their contents of major, minor, and trace elements, except for copper (Landtwing and others, 2005). 


\section{Alteration}

\section{Mineralogy}

In porphyry copper deposits, hypogene hydrothermal alteration is typically classified on the basis of mineral assemblages, discussed in more detail herein. In silicate-rich rocks, the most common alteration minerals are K-feldspar, biotite, muscovite (sericite), albite, anhydrite, chlorite, calcite, epidote, and kaolinite. In silicate-rich rocks that have been altered to advanced argillic assemblages, the most common minerals are quartz, alunite, pyrophyllite, dickite, diaspore, and zunyite. In carbonate rocks, the most common minerals are garnet, pyroxene, epidote, quartz, actinolite, chlorite, biotite, calcite, dolomite, K-feldspar, and wollastonite. Other alteration minerals commonly found in porphyry copper deposits are tourmaline, andalusite, and actinolite. Table 3 summarizes alteration minerals in selected porphyry copper deposits, worldwide.

\section{Alteration Mineral Assemblages}

Assemblages of alteration minerals are typically grouped in categories (Schwartz, 1947; Creasey, 1966; Meyer and Hemley, 1967; Rose, 1970; Beane, 1982). Potassic alteration generally includes one or more minerals in the assemblage K-feldsparbiotite-muscovite (sericite)-chlorite-quartz. Phyllic alteration includes one or more minerals in the assemblage quartz-muscovite (sericite)-pyrite-chlorite. Argillic alteration includes one or more minerals in the assemblage kaolinite ( \pm dickite)-muscovite (sericite)-montmorillonite. The "advanced-argillic" mineral assemblage is quartz-alunite-kaolinite ( \pm dickite \pm pyrophyllite. Propylitic alteration consists of one or more minerals of the assemblage chlorite-calcite-epidote-pyrite-albite.

Hydrothermal alteration reflects changes in the host-rock mineralogy in response to water/rock interactions. Thus, the general categories of alteration (for example, potassic) can consist of different combinations of the minerals previously listed; that is, different assemblages depending upon fluid and host-rock compositions. Because there may be multiple, overlapping pulses of hydrothermal fluid flow that collectively form a deposit, the host-rock composition that each sequential fluid pulse contacts may be a previously altered rock. Thus, assemblages within any particular group may be replicated at different times across a deposit and(or) may differ somewhat in relative constituent mineral abundances from preceding assemblages of the same overall mineralogy. In addition, the assemblage may vary depending upon whether the alteration is pervasive or restricted to the selvage of a vein. The mineral-assemblage complexity that may exist in a deposit is illustrated in table 4.

\section{Lateral and Vertical Dimensions}

Table 2 gives the dimensions of the alteration systems for a selection of deposits (from Singer and others, 2008). Lowell and Guilbert (1970) estimated that alteration extends, on average, $0.75 \mathrm{~km}$ beyond the limits of ore in deposits in the western Cordillera of the United States. 


\section{Vein Selvages}

As used herein, selvages refer to distinct bands of wall-rock alteration adjoining veins. Because mineral reactions vary depending upon host-rock composition, vein-margin assemblages can vary widely. Examples of vein selvage alteration for two deposits are given in table 4.

\section{Matrix}

Irrespective of the alteration category (for example, potassic), the degree of alteration of the original rock matrix can vary from 100 percent to some smaller proportion, depending upon the stability of the host-rock-forming minerals under the hydrothermal conditions and the intensity of the alteration. Except for extremely intense argillic, advanced argillic, phyllic alteration, the original texture of the host rocks is preserved.

In the potassic alteration zones in quartz-bearing host rocks, the primary quartz generally remains unaltered. In mafic mineral-bearing rocks (for example, biotite, amphibole, pyroxene), secondary biotite may be abundant together with chlorite, sulfides, sericite, a titanium-bearing phase (for example, rutile, ilmenite, sphene), epidote, and(or) calcite. Primary plagioclase is generally altered, particularly the more calcic varieties. The most common alteration phases are K-feldspar, albite-oligoclase, and sericite (compare Beane, 1982). Anhydrite is common, but its abundance varies greatly between deposits.

Intensity

The intensity of alteration can vary from 100 percent of specific primary minerals in the host rocks to partial alteration of susceptible minerals resulting in a somewhat smaller proportion of alteration of the original rock. In the most intensely altered rocks, the primary textures of the host rock may have been largely to entirely destroyed and replaced by mats of fine-grained alteration minerals, particularly biotite and(or) sericite, or, in advanced argillic alteration, mats of alunite and pyrophyllite.

\section{Textures}

In pervasively altered rock, alteration minerals tend to be finer grained than their primary antecedents. Phenocrysts are commonly pseudomorphed, but replacement minerals, whether biotite, sericite, chlorite, or some other phase, form aggregates of small grains that mimic the original crystal. Alteration minerals are subhedral to anhedral, except when they form in vugs or veins. Whether the alteration is pervasive or vein related, it is not unusual for pyrite to be euhedral.

\section{Zoning Patterns}

Despite the intrinsic complexity of hydrothermal alteration and the significant variability within and between deposits, the same general zoning of the alteration categories is macroscopically evident in most deposits. The zones are defined on the basis of their characteristic minerals as listed in the "Mineralogy" section. The compositional changes observed are the consequence of the involvement of differently sourced fluids and their mixture in the formation of a deposit. Figure 1 is a conceptual model of 
the lateral and vertical relations of the alteration zones first proposed by Lowell (1968) and later applied to many deposits in the North American Cordillera (Lowell and Guilbert, 1970).

When a deposit begins to form, there are two distinct zones that form. In the core of the upflow zone of the mineralizing magmatic fluid, potassic alteration occurs. With respect to the deposition of copper ores, potassic alteration in the core of a deposit is of predominant importance. Stable isotopic evidence, discussed in a later section, indicates that these ore-forming, magmatic fluids do not mix with surrounding ground waters. Nevertheless, the thermal gradient associated with this hightemperature upflow zone leads to convection of surrounding ground waters that results in a peripheral propylitic alteration zone. Phyllic alteration is always observed to crosscut potassic alteration, and isotopic evidence, discussed in a later section, indicates that this alteration forms from a mixture of meteoric and magmatic fluids. Phyllic alteration is associated with important tonnages of ore in some deposits but is not present as a distinct alteration type in all deposits (Sillitoe, 2000).

Clay-rich alteration assemblages, such as argillic to advanced argillic, commonly occur above the core of a deposit and laterally along the margins of the system. This upper alteration zone is sometimes referred to as a "lithocap" (for example, Sillitoe, 2000).

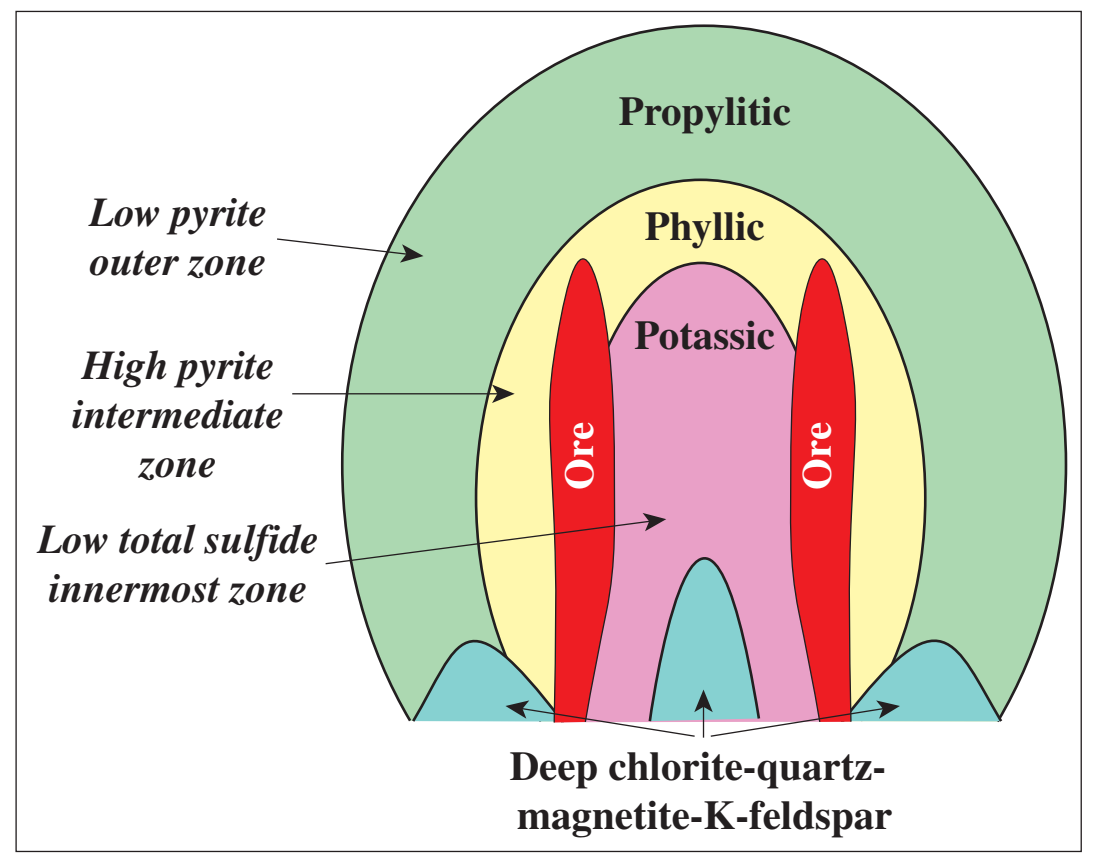

Figure 1. Cross section of a porphyry copper deposit showing idealized alteration zoning (after Lowell and Guilbert, 1970).

\section{Petrology of Associated Igneous Rocks}

\section{Rock Names}

A wide variety of igneous rock types, depending on the depth and chemical conditions of magma generation, are spatially associated with porphyry deposits, ranging from diorite to granodiorite and granite. The most common rock association 
is related to the evolution of felsic to intermediate calc-alkaline compositions (granodioritic), likely derived from more mafic mantle magmas. In island-arc settings, the crust is thinner and the host rocks are more mafic (dioritic), and in back-arc settings the host rocks are more alkaline (shoshonitic) (Richards, 2003).

\section{Forms of Igneous Rocks and Rock Associations}

Most immediately associated intrusions are small stocks, often with a greater vertical than horizontal dimension, and dikes. Other igneous rocks can vary from dikes to small stocks to batholith-scale bodies.

\section{Mineralogy}

Most common primary minerals in host quartz dioritic to granodioritic rocks include quartz, K-feldspar, plagioclase, biotite, hornblende, magnetite, zircon, apatite, and titanite. Porphyry copper-gold deposits are genetically associated with the magnetite series of granites, as defined by Ishihara (1981, and references therein). The oxidation state of the magma is largely inherited from the source region (Carmichael, 1991). Other parameters, such as magma compositional variations (for example, its degree of peraluminosity, range of alkalinity, silica, water content, and so forth) are also inherited from the source region. The compositional features and degree of magma evolution control the compatible/incompatible element distributions (Blevin and Chappell, 1992).

\section{Textures and Structures}

Most immediately associated igneous rocks are porphyritic to microporphyritic with aplitic groundmass; dikes may have aphanitic groundmass. In some deposits, minerals show preferred orientations related to flow or postemplacement deformation.

\section{Grain Size}

Grain sizes can vary from coarse to aphanitic but are predominantly intermediate to fine grained.

\section{Lithochemistry}

Porphyry copper-(molybdenum-gold) deposits are formed by magmatic-hydrothermal fluids generated from subductionrelated magmatism. Calc-alkaline igneous rocks associated with porphyry copper deposits vary from predominantly hornblende- and(or) biotite-bearing diorite to monzogranite (Cooke and others, 1998, 2005; Richards, 2003; Sinclair, 2007; Sillitoe, 1998; Sillitoe and Perelló, 2005, and references therein; Seedorff and others, 2005, and references therein). Syenogranite, quartz monzonite, and quartz monzodiorite occur in some porphyry copper deposits, and diorite and pyroxenite have also been reported from more mafic and alkalic varieties (for example, Cooke and others, 1998; Panteleyev, 1995a, b). High-potassium calc-alkalic (and alkalic) intrusions are related to gold-rich porphyry systems (for example, Cooke and others, 2005). The more mafic end of the granitic compositional spectrum is closely related to copper (-gold) mineralization (for example, Blevin and Chappell, 1992, 1995). Deposits are associated with multiphase, shallow (porphyritic rocks with aplitic groundmass), moderately evolved 
granitic rocks (as judged by chemical parameters such as $\mathrm{K} / \mathrm{Rb}$, and $\mathrm{Rb} / \mathrm{Sr}$ ratios, and moderate silica contents), sulfur-rich, and oxidized (high values of $\mathrm{Fe}_{2} \mathrm{O}_{3} / \mathrm{FeO}$ in bulk rock; belonging to magnetite-series, titanite+magnetite-bearing granitic rocks) magmatic systems (intrusions and volcanic rocks). Seedorff and others (2005) found that porphyry deposits in the Western United States are spatially, temporally, and genetically related to metaluminous to weakly peraluminous, and intermediate to silicic stocks $\left(\mathrm{SiO}_{2}>56 \mathrm{wt}\right.$ percent). White (2004) suggested that porphyry copper deposits in the Western United States were associated predominantly with high-temperature quartz monzonite characterized by relatively high contents of $\mathrm{K}_{2} \mathrm{O}+\mathrm{Na}_{2} \mathrm{O}, \mathrm{K}_{2} \mathrm{O} / \mathrm{Na}_{2} \mathrm{O}$ $>1$, and $\mathrm{Ba}>1,000 \mathrm{ppm}$.

\section{Trace-Element Geochemistry}

The modern level of understanding of the chemical evolution of magmatic systems and porphyry copper deposits is not precise enough to predict the exact geochemical features that distinguish mineralized from barren plutons. However, important advances have been made in some cases. For example, Lang and Titley (1998) found that rare-earth element (REE) chondritenormalized patterns of productive plutons in Arizona have steeper slopes, lower total REE contents, increasing upward concavity in the heavy-REE, and less negative to positive europium anomalies relative to nonproductive stocks; the high-field-strength elements (zirconium, hafnium, tantalum, niobium), and manganese and yttrium are depleted in productive stocks compared to nonproductive stocks. Baldwin and Pearce (1982), Kay and others (1999), Richards and others (2001), and Richards (2003) noted compositional distinctions in the Andes, including productive intrusions associated with porphyry deposits that show fractionated REE patterns and depletions for manganese, thorium, yttrium, and the heavy-REE compared to barren plutons. Major porphyry deposits in the Peruvian-Chilean belt are also known to have formed late within a magmatic cycle, hosted by more chemically evolved rocks that are assigned to the last intrusive event in the region (for example, host dacites evolving from cogenetic diorites; Richards, 2003 and references therein). In such cases, the heavy-REE and yttrium depletions are attributed to amphibole and(or) deep-crustal garnet fractionation and the low manganese to loss of manganese-rich fluids from the magma.

\section{Stable Isotope Geochemistry}

Early work by Sheppard and colleagues (for example, Sheppard and others, 1969; Sheppard and Gustafson, 1976) using oxygen and hydrogen isotopes showed that magmatic fluid dominates the early, high-temperature stages of porphyry evolution and formation of biotite $\pm \mathrm{K}$-feldspar (potassic alteration); a component of meteoric water subsequently overprints the early hydrothermal stages producing muscovite \pm pyrite assemblages (phyllic alteration) and clay-bearing assemblages (argillic alteration) at lower temperatures (Hedenquist and Richards, 1998; Seedorff and others, 2005, and references therein). Magmatic fluids dominate acidic alteration associated with ore (for example, Watanabe and Hedenquist, 2001). Ohmoto and Rye (1979) found that sulfides and sulfates in porphyry copper deposits from the American Cordillera were deposited from fluids carrying sulfur of predominantly magmatic origin. 


\section{Radiogenic Isotope Geochemistry}

The typical association of porphyry copper deposits and ordinary calc-alkaline magmas points to commonly accepted and standard genetic processes of magma generation in magmatic arcs involving melting of the metasomatized mantle wedge (Richards, 2003). In many study areas, the current level of knowledge of the tectonic history, age relationships, and structural evolution are not sufficient to recognize regionally systematic isotopic signatures that can be attributed to diagnostic mantle or crustal sources forming porphyry copper deposits. Moreover, calc-alkaline magmas that have been thought to be intrinsically capable of producing copper-rich fluids and porphyry copper deposits appear to require no exceptional sources (Dilles, 1987; Cline and Bodnar, 1991).

Recent studies have shown, however, large-scale regional isotopic variations ascribed to source or to magmatic processes during transfer through the crust. For example, studies of lead-strontium-neodymium-osmium isotopes link deposits in the Andes to mantle-derived magmas with contributions from the continental crust (Hedenquist and Richards, 1998; Ruiz and Mathur, 1999; Sillitoe and Perelló, 2005); in southwestern Arizona, the isotopes reflect a large contribution from the continental crust (Anthony and Titley, 1988; Lang and Titley, 1998). Homogeneous lead isotope ratios characterize individual eastwardyounging metallogenic belts in the Andes (Tosdal and others, 1999, and references therein), in contrast to regionally heterogeneous ratios in southwestern Arizona (Wooden and others, 1988; Bouse and others, 1999). Neodymium and strontium isotope ratios do not distinguish between mineralized and barren systems in North America (Farmer and DePaolo, 1984). The osmium isotope ratios point to the relative contributions of copper from the mantle and crust (Ruiz and Mathur, 1999). In the larger deposits in Chile, the initial osmium isotope ratios are less radiogenic, suggesting that such deposits acquire relatively more osmium from the mantle (Mathur and others, 2000). Long-term underplating of basalt and recycling of mafic crust produced significantly thickened crust in the Andes; systematic changes in neodymium-strontium-lead ratios from west to east have also been found (Haschke and others, 2002).

\section{Depth of Emplacement}

We believe that most deposits formed between about 1.5- and 3-4-km depth. Other investigators have estimated some formation depths in the range between 4-5 (Sutherland Brown, 1976) and 6-9 km (Rusk and others, 2008). A summary of published estimates is given in Singer and others (2008).

\section{Theory of Deposit Formation}

\section{System Affiliation(s)}

Seedorff and others (2005) noted that porphyry copper deposits can be associated with high-sulfidation epithermal deposits (copper, gold, silver), late and(or) distal intermediate-sulfidation polymetallic base metal and precious element veins (lead, manganese, zinc, silver), and distal disseminated gold deposits. Sillitoe and Perelló (2005) described iron-oxide-copper-gold, manto copper, copper-bearing volcanogenic massive sulfide deposits, and copper skarns (copper-zinc-molybdenum-silver) spatially associated with porphyry copper belts in the Andes. Jensen and Barton (2000) described alkalic porphyry systems with 
intermediate-sulfidation epithermal base-metal-gold-telluride deposits. Porphyry copper deposits can exhibit regional or districtscale zoning, from a porphyry core associated with proximal skarns to distal polymetallic veins and replacement deposits.

\section{Controls on Permeability and Fluid Flow}

Deposits may be broadly related to regional and pull-apart structures at dilational bends, strike-slip faults, shear zones, duplexes, pull-apart basins, and grabens. At the local scale, extensive sets of fractures develop in response to hydraulic fracturing.

\section{Sources of Fluids and Metals}

The calc-alkaline nature of the magmas reflects melting of various sources (mafic rocks) including those in the mantle wedge (modified by metasomatism of fluid-soluble elements and melts during subduction), magma ponding and reaction at the base of the continental crust (hybridization, mafic and felsic magma mixing), and metasomatism during ascent through thickened crust (for example, Richards, 2003). These fundamental aspects of magma production in continental margins point to multiple, multistage processes that were first summarized by Hildreth and Moorbath (1988) as the melting, assimilation, storage, and homogenization (MASH) model to explain crustal contributions to Andean arc magmatism. Such a diversity of magma sources and multistage igneous processes invoked for magma genesis suggests that multiple metal sources are involved in porphyry copper deposits. The mantle likely provides most of the copper, gold, and platinum-group elements, and the crust provides most of the molybdenum and lead.

\section{Chemical Transport and Transfer Processes}

Fluid-phase separation in porphyry copper deposits controls ore-metal fractionation and sulfide mineral precipitation and results from density variations and degree of miscibility of saline fluids (Heinrich, 2007). Extensive magma evolution in the shallow crustal environment produces supersaturation of volatile phases and an aqueous phase that ponds in the periphery and above the crystallizing magma chamber. Aqueous fluid has commonly been thought to be the main agent of metal transport in porphyry copper deposits, but the function of vapor transfer was first proposed for the formation of porphyry deposits by Henley and McNabb (1978). Williams-Jones and Heinrich (2005) recently evaluated the function of aqueous vapor as an agent of metal transport in natural systems and in the laboratory and concluded that vapor, instead of aqueous fluid, is the main transporting agent. Other recent studies of porphyry copper deposits have also shown that copper and gold partition into the vapor (Heinrich and others, 1999; Ulrich and others, 1999). Parental magmas producing porphyry copper deposits may not be highly crystallized or represent an advanced stage of evolution. Sinclair (2007) summarized evidence for highly reactive volatile streams originating deep within a magma reservoir (more mafic zones? separate reservoirs?), acquiring metals during transport, and ponding in cupolas (without triggering an eruption). These large volumes of volatiles and ore-forming fluids strip metals during ascent, depressing the liquidus temperatures of granitic magmas in the cupolas. Compositionally zoned magma reservoirs and caldera processes involving resurgence of less felsic, deeper, hotter magmas appear to be involved with the generation of highly reactive, volatile streams. Richards (2003) suggested that caldera and ignimbrite complexes are probably not prospective for porphyry 
copper deposits because large caldera-forming eruptions are expected to obliterate magmatic-hydrothermal systems, and ignimbrites predominantly reflect crustal melts that are relatively depleted in sulfur and chalcophile metals.

\section{Heat Transport and Transfer Processes}

Cooling of magmatic-hydrothermal fluids from about $750^{\circ}$ to $600^{\circ} \mathrm{C}$ (depending on magmatic composition) to less than $200^{\circ} \mathrm{C}$ (Ulrich and others, 2001) promotes supersaturation of ore and alteration minerals (Hemley and Hunt, 1992).

\section{Pressure Gradients during Ore Formation}

Magma reservoirs are dynamic and chemically open systems that de-gas, assimilate crust, recharge with new fluxes of mafic melts at their base, and mix different compositional zones during magma evolution. Magma composition and water content, together with the depth of the reservoir and hydrologic regime, establish important constraints on ore deposition; near the magma reservoir at high temperature, overpressured and lithostatic conditions occur, but at temperatures less than $375^{\circ} \mathrm{C}$, hydrostatic conditions dominate (Seedorff and others, 2005). Multiple batches of porphyry magma (dikes, plugs) intrude into the ore zone, possibly creating breccias and hydraulic fractures. At low pressures ( $<1.5 \mathrm{kbars})$ brine-vapor-phase separation controls metal partitioning and solubility (Heinrich and others, 1999; Heinrich, 2007).

\section{Wall-Rock Reaction and Ore-Mineral Deposition Processes}

Wall-rock composition affects the alteration and ore mineral assemblage by buffering the $\mathrm{pH}$ and oxidation state of the system.

\section{Weathering}

Weathering, resulting in oxidation and(or) supergene enrichment, is an important process in the economic viability of many porphyry copper deposits (for example, Sillitoe and McKee, 1996). The oxidation and acid leaching of primary mineralization may produce zones of enrichment near the base of the weathering zone (Hartley and Rice, 2005). Primary rock composition and postmineralization hydrogeology, together with one or more cycles of uplift and(or) climate change, are important to the formation of an economically viable deposit. Prominent examples of oxidation and supergene enrichment include the deposits at Morenci, Arizona, and Chuquicamata, Chile.

The mineralogy of weathered deposits has been discussed in detail by Anderson (1982), Alpers and Brimhall (1989), and Sillitoe (2005). Common minerals in strongly leached rocks, referred to as "leached caps," include goethite, jarosite, hematite, gypsum, alunite, and kaolinite. Supergene and oxide minerals include malachite, azurite, chrysocolla, neotocite, cuprite, chalcocite, covellite, djurleite, digenite, anilite, and idaite. Cook (1988) described copper-bearing mineral assemblages at the Lakeshore mine in Arizona, as follows: chalcocite zone, brochantite zone, chrysocolla zone, copper wad zone, and goethite zone. These zones do not form distinct horizons but occur throughout the supergene orebodies. 


\section{Zoning and Geochemistry}

Supergene enrichment processes are important because potential ore metals, such as copper and silver, are concentrated during supergene oxidation, while other metals are removed by the solutions (Hartley and Rice, 2005). At the Lakeshore mine in Arizona, Cook (1988) found chrysocolla mineralization to be in a particular host rock, granodiorite porphyry, with half of the copper in altered phenocrysts of biotite and plagioclase together with clay minerals. There was a complete range of chemical compositions from chrysocolla to copper-bearing clay. Other chrysocolla deposition at Lakeshore was fracture controlled. In the brochantite zone, Cook (1988) found the brochantite to occur principally in fractures and oxidized hypogene quartz veinlets. The goethite zone at Lakeshore occurs as a layer against overlying postmineralization rocks. Although the goethite zone carries 0.3 percent copper, blue and green copper oxide minerals are rare. The cuprite zone occurs as a layer separating brochantite and chrysocolla zones from the chalcocite zone in the deepest part of the supergene orebody.

The geochemistry is reflective of the oxide mineral assemblage; thus, its complexity depends on the complexity of the assemblage mix. For example, in a profile across the goethite, chrysocolla, and chalcocite zones at Lakeshore, Cook (1988) found $\mathrm{SiO}_{2}, \mathrm{Al}_{2} \mathrm{O}_{3}, \mathrm{MgO}$, and $\mathrm{Na}_{2} \mathrm{O}$ to be depleted in all three zones, but the amount of $\mathrm{SiO}_{2}$ depletion is a function of the copper content. The silica depletion reflected the amount of chrysocolla present; that is, the greatest depletion was in the goethite zone. The ratio of $\mathrm{Fe}^{+++}$to $\mathrm{Fe}^{++}$increased, but the total iron concentration did not. The $\mathrm{CaO}$ was depleted in the goethite zone, but gypsum was present in the chalcocite zone. Copper oxide was enriched across the whole profile. For additional discussion, the reader is referred to Anderson (1982), Alpers and Brimhall (1989), Chávez (2000), and Sillitoe (2005).

\section{Rates}

A detailed understanding of the importance of multiple weathering cycles and weathering rates requires careful petrographic study and detailed age information. Although analytical methods such as ${ }^{40} \mathrm{Ar} /{ }^{39} \mathrm{Ar}$ have been applied to the problem, a great deal of care in sampling, sample preparation and analysis, and data interpretation is required to obtain meaningful results. Growth bands indicative of multiple depositional events often can only be documented as a period during which oxidation took place but may not yield rates of weathering (for example, Mote and others, 2001). At El Salvador, Chile, Mote and others (2001) found weathering to have begun within 6 m.y. (about 36-35 Ma) of the end of hypogene mineralization at about 41 Ma. Multiple supergene events were identified (35 Ma, $25 \mathrm{Ma}, 14 \mathrm{Ma}, 11 \mathrm{Ma}$ ), with the youngest episode being the $\sim 11 \mathrm{Ma}$ event. Mote and others (2001) concluded that the supergene events were driven by regional to global climatological events, including global climate change near the Eocene-Oligocene boundary. For additional discussion of rates, the reader is referred to Sillitoe (2005).

\section{Geoenvironmental Features}

The following discussions are expanded from Cox and others (1995). 


\section{Pre-Mining Baseline Signatures in Soil, Sediment, and Water}

Baseline characterization studies of porphyry copper deposits are limited in the literature, particularly in regard to the diversity of climatic settings in which they are found. Therefore, extrapolation of the insights provided by the case studies summarized herein to other deposits should be done with caution. Data from tropical Tanamá, Puerto Rico (Learned and others, 1972), show different metal abundances in the B-horizon of residual soil over magnetite-rich (1.4 wt-percent sulfur) and pyrite-rich (2.5 wt-percent sulfur) copper ore zones. These data illustrate how acid, which is released as pyrite oxidizes, leaches metals from soil. An exception is molybdenum, which is not readily leached in low-pH environments. Chaffee and others (1981) indicated that stream sediment from the area draining the unmined Red Mountain porphyry copper deposit in arid southeastern Arizona contains elevated abundances of molybdenum, lead, and tellurium. The Mineral Butte and Vekol, Arizona, deposits are other arid-climate porphyry-copper deposits for which pre-mining geochemical data are available. Chaffee (1976, table 1, and 1977, table 3) presents ranges, backgrounds, and geochemical anomaly thresholds for manganese, cadmium, copper, cobalt, fluorine, gold, lead, bismuth, mercury, molybdenum, silver, and zinc abundances in bedrock and residual soil samples collected in the vicinity of these deposits. Abundances of most of these elements are elevated in the vicinity of these deposits relative to those characteristic of other geologic environments; these elevated abundances identify appropriate baseline geochemical values that may be useful in setting remediation standards for mines associated with this deposit type in arid climates.

Leybourne and Cameron (2006) documented high-salinity ground waters associated with the unmined Spence deposit in the Atacama Desert, Chile, reaching 10,000 to 55,000 mg/L, with one outlier at 145,000 mg/L. The $\mathrm{pH}$ of the ground waters varied widely between 4.7 and 9.2. Dissolved sulfate concentrations in ground waters were between 5,000 and 10,000 mg/L. PlazaToledo (2005) found surface waters downstream from unmined porphyry copper deposits in the Cordillera Central of Puerto Rico to reach maximum dissolved concentrations of $110 \mathrm{mg} / \mathrm{L}$ sulfate, $0.56 \mathrm{mg} / \mathrm{L}$ aluminum, $0.13 \mathrm{mg} / \mathrm{L}$ copper, $15.9 \mathrm{mg} / \mathrm{L}$ iron, and $0.04 \mathrm{mg} / \mathrm{L}$ zinc. The $\mathrm{pH}$ was high (7.7-8.6).

\section{Past and Future Mining Methods and Ore Treatment}

Most porphyry copper deposits are mined by open-pit methods and, less commonly, by underground methods. For those deposits with associated skarns, underground or open-pit mining methods may be used to mine the skarn deposits. Sulfide ores are generally crushed to a fine-grain size, and ore minerals (chalcopyrite, bornite, molybdenite, and pyrite, if gold-bearing) are separated by conventional flotation methods to form a concentrate. Gold-bearing pyrite concentrates may be roasted onsite to oxidize the pyrite prior to treatment with cyanide to extract the gold. Low-grade and oxide ores may undergo less intensive crushing prior to being treated by solvent-extraction electrowinning (SX-EW) methods with acidic solutions on leach pads to extract copper (Lynch and others, 1994).

\section{Volume of Mine Waste and Tailings}

Due to the low percentages of ore minerals typically associated with porphyry copper deposits, the tonnages of flotation tailings and SX-EW leach-pad wastes are essentially identical to the tonnages of the deposits being mined. Volumes of waste rock will depend upon the depth of the deposit, the geometry of the deposit, and the competency of the country rock as it relates 
to stripping ratios. On average, about 1.5 tons of waste rocks and overburden must be removed for every ton of ore grade mined (Phillips and Niemuth, 1993).

\section{Mine Waste Characteristics}

Mineralogy: In addition to the primary minerals associated with the ores, a number of secondary minerals can form in the mine wastes. These include jarosite, schwertmannite, ferrihydrite, goethite, manganese hydroxides, authigenic clays, covellite, pickeringite, bonattite, chalcanthite, melanterite, and rozenite (Dold and Fontboté, 2001; Hansen and others, 2005).

\section{Acid-Base Accounting}

Net neutralization potentials reported in the literature for tailings from several porphyry copper deposits in Chile are net acid, ranging from -101.6 to -18.2 kilograms calcium carbonate per ton $\left(\mathrm{kg} \mathrm{CaCO}_{3} / \mathrm{t}\right)$ (Dold and Fontboté, 2001). Net neutralizing potentials for hypogene and supergene ores from Morenci, Arizona, range from dominantly net acid to slightly net alkaline (-257.0 to $1.1 \mathrm{~kg} \mathrm{CaCO}_{3} / \mathrm{t}$; Enders and others, 2006).

\section{Metal Mobility Related to Mining in Ground Water and Surface Water}

The interaction between a porphyry copper deposit and the environment is illustrated by a stream in the Globe mining district in Arizona that was blocked by mill tailings, causing a lake to form. Water from this lake entered an alluvial aquifer by seepage; the aquifer and a stream to the north were contaminated (Eychaner, 1991; Stollenwerk, 1994; Brown and others,

1998; Lind and others, 1998; Conklin and others, 2001). The most contaminated ground water in the aquifer had a pH of 3.3 and contained about 9,600 mg/L sulfate, 2,800 mg/L iron, $300 \mathrm{mg} / \mathrm{L}$ aluminum, and $190 \mathrm{mg} / \mathrm{L}$ copper. As the plume traveled north through the aquifer, the concentration of constituents decreased as the plume interacted with carbonate-bearing alluvium and was diluted by uncontaminated water (ground water flowing upward from lower basin fill, water in uncontaminated streams that join the contaminated wash, and surface rainwater).

Enders and others (2006) reported analyses of seeps and springs in the Morenci district of Arizona, which had pH values between 2.6 and 4.6, and specific conductance values between 1,400 and 6,000 $\mu \mathrm{S} / \mathrm{cm}$. Sulfate concentrations were between 550 and 4,300 mg/L, iron between 15 and $420 \mathrm{mg} / \mathrm{L}$, aluminum between 0.48 and $370 \mathrm{mg} / \mathrm{L}$, copper between 0.46 and $960 \mathrm{mg} / \mathrm{L}$, and zinc between 0.8 and $159 \mathrm{mg} / \mathrm{L}$.

\section{Pit Lakes}

Pit lakes, particularly in porphyry copper mining districts that are riddled with historical underground mine workings, such as that at Butte, Montana, which has a 140-year mining history, can be problematic. The Berkeley pit lake at Butte contains more than 100 billion liters of pH-2.5 mine water (Gammons and others, 2005; Gammons and Duaime, 2005). The pit lake has high dissolved solids greater than $7 \mu \mathrm{S} / \mathrm{cm}$ ) and elevated concentrations of iron, copper, zinc, and sulfate (Gammons and Duaime, 2005). 


\section{Ecosystem Issues}

Acidic mine drainage and associated dissolved metals may pose threats to surrounding aquatic ecosystems depending upon geologic and hydrologic setting and engineering aspects of the mine and the waste piles. Host rocks with higher neutralization potentials, such as carbonate rocks, tend to limit the mobility of metals and related compounds. Hydrologic and climatic settings that are subject to distinct wetting and drying cycles associated with waste piles tend to promote the formation of efflorescent metal sulfate salts that may cause acute toxic effects to aquatic ecosystems if drainage directly enters surface waters. Improperly constructed water-containment structures may allow contaminated mine waters to enter surrounding surface waters.

Acidity will be associated with the $\mathrm{pH}$ of the water and the dissolved concentrations of ferrous and ferric iron, aluminum, and manganese; thus, because of incomplete hydrolysis of these elements and incomplete oxidation of dissolved iron and manganese, the $\mathrm{pH}$ may provide an inaccurate portrayal of the acidity of mine drainage (and Cravotta, $2005 \mathrm{a}, \mathrm{b}$ ). Elements or compounds with the greatest likelihood of causing problems for aquatic ecosystems and drinking-water sources for terrestrial organisms include, in alphabetical order, aluminum, arsenic, copper, iron, manganese, sulfate, and zinc.

\section{Human Health Issues}

Contaminated ground-water plumes associated with tailings impoundments may pose threats to drinking-water supplies, depending upon hydrologic and geologic setting and engineering aspects of the mine and the waste piles. Host rocks with higher neutralization potentials, such as carbonate rocks, tend to limit the mobility of metals and related compounds. Hydrologic and climatic settings that experience net evaporative loss of water may cause evaporative concentration of solutes that may enter ground water used as drinking-water supplies in the vicinity of mines and waste piles. Improperly constructed water-containment structures may allow contaminated mine waters to enter surrounding ground water. Elements or compounds with the greatest likelihood of causing problems for aquatic ecosystems, and drinking-water sources for terrestrial organisms include, in alphabetical order, aluminum, arsenic, copper, iron, manganese, sulfate, and zinc.

\section{Climate Effects on Geoenvironmental Signatures}

The understanding of the effects of various climate regimes on the geoenvironmental signature specific to porphyry copper deposits is limited. In most cases, the intensity of environmental impact associated with sulfide-mineral-bearing mineral deposits is greater in wet climates than in dry climates. Acidity and total metal concentrations in mine drainage in arid environments are several orders of magnitude greater than in more temperate climates because of the concentrating effects of mine-effluent evaporation and the resulting "storage" of metals and acidity in highly soluble metal-sulfate-salt minerals. However, minimal surface-water flow in these areas inhibits generation of significant volumes of highly acidic, metal-enriched drainage. Concentrated release of these stored contaminants to local watersheds may be initiated by precipitation following a dry spell. Present surface and near-surface chemical relations and mineral assemblages may reflect pre-existing (wetter) climate in the Southwestern United States. Dold and Fontboté (2001) investigated the environmental-geochemical characteristics of tailings from Chilean porphyry copper deposits in hyperarid, Mediterranean, and alpine climates. They concluded that climatic variations provide fundamental controls on the mobility of metals. Under precipitation-dominant conditions, divalent metals such as copper, zinc, and manganese are leached in the oxidized zone of mine waste piles, are carried downward, and are sequestered in the piles due to 
replacement sulfide minerals in the reduced zone of mine waste piles. Under evaporation-dominant conditions, leached solutes are carried upward due to capillary action and form efflorescent metal-sulfate salts, which are then available for later dissolution during heavy rainstorms or snowmelt events.

\section{Grade and Tonnage Models}

Grades and tonnages for porphyry copper deposits are detailed in a complementary open-file report by Singer and others (2008).

\section{References}

Alpers, C.N., and Brimhall, G.H., 1989, Paleohydrologic evolution and geochemical dynamics of cumulative supergene metal enrichment at La Escondida, Atacama Desert, northern Chile: Economic Geology, v. 84, p. 229-255.

Ambrus, J., 1977, Geology of the El Abra porphyry copper deposit, Chile: Economic Geology, v. 72, p. 1062-1085.

Anderson, C.A., Scholz, E.A., and Strobell, Jr., J.D., 1955, Geology and ore deposits of the Bagdad area, Yavapai County, Arizona: U.S. Geological Survey Professional Paper 278, 103 p.

Anderson, J.A., 1982, Characteristics of leached capping, in Titley, S.R., ed., Advances in geology of the porphyry copper deposits: Tucson, The University of Arizona Press, p. 275-295.

Anthony, E.Y., and Titley, S.R., 1988, Progressive mixing of isotopic reservoirs during magma genesis at the Sierrita porphyry copper deposit, Arizona-Inverse solutions: Geochimica et Cosmochimica Acta, v. 52, p. 2235-2249.

Arif, J., and Baker, T., 2004, Gold paragenesis and chemistry at Batu Hijau, Indonesia: Implications for gold-rich porphyry copper deposits: Mineralium Deposita, v. 39, p. 523-535.

Augé, T., Petrunov, R., and Bailly, L., 2005, On the origin of the PGE mineralization in the Elatsite porphyry Cu-Au deposit, Bulgaria-Comparison with the Baula-Nuasahi complex, India, and other alkaline PGE-rich porphyries: The Canadian Mineralogist, v. 43, p. 1355-1372.

Babcock, R.C., Jr., Ballantyne, G.H., and Phillips, C.H., 1995, Summary of the geology of the Bingham district, Utah, in Pierce, F.W., and Bolm, J.G., eds., Porphyry copper deposits of the American Cordillera: Arizona Geological Society Digest 20, p. $316-335$.

Baldwin, J.A., and Pearce, J.A., 1982, Discrimination of productive and nonproductive porphyritic intrusions in the Chilean Andes: Economic Geology, v. 77, p. 664-674.

Bamford, R.W., 1972, The Mount Fubilan (Ok Tedi) porphyry copper deposit, Territory of Papua and New Guinea: Economic Geology, v. 67, p. 1019-1033.

Barra, F., Ruiz, J., Mathur, R., and Titley, S., 2003, A Re-Os study of sulfide minerals from the Bagdad porphyry Cu-Mo deposit, northern Arizona, USA: Mineralium Deposita, v. 38, p. 585-596. 
Bauer, H.L., Jr., Breitrick, R.A., Cooper, J.J., and Anderson, J.A., 1966, Porphyry copper deposits in the Robinson mining district, Nevada, in Titley, S.R., and Hicks, C.L., eds., Geology of the porphyry copper deposits, southwestern North America: Tucson, The University of Arizona Press, p. 233-244.

Beane, R.E., 1982, Hydrothermal alteration in silicate rocks, in Titley, S.R., ed., Advances in geology of the porphyry copper deposits, southwestern North America: Tucson, The University of Arizona Press, p. 117-137.

Behn, G., Camus, F., and Carrasco, P., 2001, Aeromagnetic signature of porphyry copper systems in northern Chile and its geologic implications: Economic Geology, v. 96, p. 239-248.

Berger, B.R., and Drew, L.J., 1998, Mineral-deposit models: New developments, in Fabbri, A.G., Gaál, G., and McCammon, R.B., eds., Deposit and Geoenvironmental models for resource exploitation and environmental security: Boston, Kluwer Academic Publishers, NATO Science Series, p. 121-134.

Berger, B.R., King, T.V.V., Morath, L.C., and Phillips, J.D., 2003, Utility of high-altitude infrared spectral data in mineral exploration-Application to northern Patagonia Mountains, Arizona: Economic Geology, v. 98, p. $1003-1018$.

Beus, A.A., and Grigorian, S.V., 1977, Geochemical exploration methods for mineral deposits: Wilmette, Illinois, Applied Publishing Ltd., 287 p.

Blevin, P.L., and Chappell, B.W., 1992, The role of magma sources, oxidation states and fractionation in determining the granitoid metallogeny of eastern Australia: Transactions of the Royal Society of Edinburgh, Earth Sciences, v. 83, p. 305-316.

Blevin, P.L., and Chappell, B.W., 1995, Intrusive metallogenic provinces in eastern Australia based on granite source and composition: Transactions of the Royal Society of Edinburgh, Earth Sciences, v. 87, p. 281-290.

Bodnar, R.J., 1995, Fluid inclusion evidence for a magmatic source of metals in porphyry copper deposits, in Thompson, J.F.H., ed., Magmas, fluids, and ore deposits: Mineralogical Association of Canada Short Course, v. 23, p.139-152.

Bodnar, R.J., and Cline, J.S., 1991, Fluid inclusion petrology of porphyry copper deposits revisited-Re-interpretation of observed characteristics based on recent experimental and theoretical data: Plinius, v. 5, p. 24-25.

Bouley, B.A., St. George, P., and Wetherbee, P.K., 1995, Geology and discovery at Pebble copper, a copper-gold porphyry system in southwest Alaska, in Schroeter, T.G., ed., Porphyry deposits of the northwestern Cordillera of North America: Canadian Institute of Mining, Metallurgy and Petroleum, Special Volume 46, p. 422-435.

Bouse, R.M., Ruiz, J., Titley, S.R., Tosdal, R.M., and Wooden, J.L., 1999, Lead isotopic compositions of Late Cretaceous and Early Tertiary igneous rocks and sulfide minerals in Arizona-Implications for the sources of plutons and metals in porphyry copper deposits: Economic Geology, v. 94, p. 211-244.

Brown, J.G., Bassett, R.L., and Glynn, P.D., 1998, Analysis and simulation of reactive transport of metal contaminants in ground water in Pinal Creek Basin, Arizona: Journal of Hydrology, v. 209, p. 225-250.

Bryant, D.G., and Metz, H.E., 1966, Geology and ore deposits of the Warren mining district, in Titley, S.R., and Hicks, C.L., eds., Geology of the porphyry copper deposits, Southwestern North America: Tucson, The University of Arizona Press, p. 189-203.

Burnham, C.W., 1979, Magmas and hydrothermal fluids, in Barnes, H.L., ed., Geochemistry of hydrothermal ore deposits, 2d ed: New York, Wiley, p. 71-136.

Camus, F., 1975, Geology of the El Teniente orebody with emphasis on wall-rock alteration: Economic Geology, v. 70, p. 1341-1372.

Candela, P.A., and Blevin, P.L., 1995, Do some miarolitic granites preserve evidence of magmatic volatile phase impermeability?: Economic Geology, v. 90, p. 2310-2316. 
Cannell, J., Cooke, D.R., Walshe, J.L., and Stein, H., 2005, Geology, mineralization, alteration, and structural evolution of the El Teniente porphyry Cu-Mo deposit: Economic Geology, v. 100, p. 979-1003.

Carmichael, I.S.E., 1991, The redox states of basic and silicic magmas-A reflection of their source regions?: Contributions to Mineralogy and Petrology, v. 106, p. 129-141.

Chaffee, M.A., 1976, Geochemical exploration techniques based on distribution of selected elements in rocks, soils, and plants, Mineral Butte copper deposit, Pinal County, Arizona: U.S. Geological Survey Bulletin 1278-D, p. D1-D55.

Chaffee, M.A., 1977, Geochemical exploration techniques based on distribution of selected elements in rocks, soils, and plants, Vekol porphyry copper deposit area, Pinal County, Arizona: U.S. Geological Survey Bulletin 1278-E, 78 p.

Chaffee, M.A., 1982, A geochemical study of the Kalamazoo porphyry copper deposit, Pinal County, Arizona, in Titley, S.R., ed., Advances in geology of the porphyry copper deposits, Southwestern North America: Tucson, The Arizona University Press, p. 211-224.

Chaffee, M.A., 1992, Data for four drill holes, Kalamazoo porphyry copper deposit, Pinal County, Arizona: U.S. Geological Survey Open-File Report 92-238-A, 50 p., and 92-238-B (diskette).

Chaffee, M.A., 1994, Data for four drill holes, Mount Margaret copper-molybdenum-gold deposit, Skamania County, Washington: U.S. Geological Survey Open-File Report 94-2-A, 10 p., and 94-2-B (diskette).

Chaffee, M.A., Hill, R.H., Sutley, S.J., and Waterson, J.R., 1981, Regional geochemical studies in the Patagonia Mountains, Santa Cruz County, Arizona: Journal of Geochemical Exploration, v. 14, p. 135-153.

Chávez, W.X., 2000, Supergene oxidation of copper deposits-Zoning and distribution of copper oxide minerals: Society of Economic Geologists Newsletter, no. 41, April 2000, p. 1, 10-21.

Clark, R.N., Swayze, G.A., Livo, K.E., Kokaly, R.F., Sutley, S.J., Dalton, J.B., McDougal, R.R., and Gent, C.A., 2003, Imaging spectroscopy: Earth and planetary remote sensing with the USGS Tetracorder and expert systems: Journal of Geophysical Research., v. 108(E12), 5131, doi:10.1029/2002JE001847, pages 5-1 to 5-44. Accessed at: http://speclab.cr.usgs.gov/ PAPERS/tetracorder

Clark, R.N., Swayze, G.A., Wise, R., Livo, K.E., Hoefen, T.M., Kokaly, R.F., and Sutley, S. J., 2007, USGS Digital Spectral Library splib06a: U.S. Geological Survey, Data Series 231. Accessed at: http://speclab.cr.usgs.gov/spectral.lib06/ds231/ datatable.html

Cline, J.S., and Bodnar, R.J., 1991, Can economic porphyry copper mineralization be generated by a typical calc-alkaline melt?: Journal of Geophysical Research, v. 96, p. 8113-8126.

Conklin, M., Villinski, J., and Kay, J., 2001, Geochemistry of acid mine contamination-aquifer interactions: International Journal of Occupational Health, v. 14, p. 249-259.

Cook, S.S., 1988, Supergene copper mineralization at the Lakeshore mine, Pinal County, Arizona: Economic Geology, v. 83, p. 297-309.

Cooke, D.R., Hollings, P., and Walshe, J.L., 2005, Giant porphyry deposits-Characteristics, distribution, and tectonic controls: Economic Geology, v. 100, p. 801-818.

Cooke, D.R., Heithersay, P.S., Wolfe, R., and Calderon, A.L., 1998, Australian and western Pacific porphyry Cu-Au deposits: Journal of Australian Geology and Geophysics, v. 17, no. 4, p. 97-104. Accessed at: http://www.ga.gov.au/about/corporate/ ga_authors/ajagg_17_4/DR_Cooke_etal_ajagg174.jsp

Cox, D.P., and Singer, D.A., 1988, Distribution of gold in porphyry copper deposits: U.S. Geological Survey Open-File Report $88-46,22 \mathrm{p}$. 
Cox, L.J., Chaffee, M.A., Cox, D.P., and Klein, D.P., 1995, Porphyry Cu deposits: U.S. Geological Survey Open-File Report 95-831, p. 75-89.

Creasey, S.C., 1966, Hydrothermal alteration, in Titley, S.R., and Hicks, C.L., eds., Geology of the porphyry copper deposits, southwestern North America: Tucson, The University of Arizona Press, p. 51-74.

Deckart, K., Aguilar A., C., Vargas R., R., Bertens N., A., Mortensen, J., and Fanning, M., 2005, Magmatic and hydrothermal chronology of the giant Río Blanco porphyry copper deposit, central Chile-Implications of an integrated U-Pb and ${ }^{40} \mathrm{Ar} /{ }^{39} \mathrm{Ar}$ database: Economic Geology, v. 100, p. 905-934.

Dilles, J.H., 1987, Petrology of the Yerington batholith, Nevada—Evidence for evolution of porphyry copper ore fluids: Economic Geology, v. 82, p. 1750-1789.

Dixon, D.W., 1966, Geology of the New Cornelia mine, Ajo, Arizona, in Titley, S.R., and Hicks, C.L., eds., Geology of the porphyry copper deposits, southwestern North America: Tucson, The University of Arizona Press, p. 123-132.

Dold, B., and Fontboté, 2001, Element cycling and secondary mineralogy in porphyry copper tailings as a function of climate, primary mineralogy, and mineral processing: Journal of Geochemical Exploration, v. 74, p. 3-55.

Drew, L.J., 2006, A tectonic model for the spatial occurrence of porphyry copper and polymetallic vein deposits-Applications to Central Europe: U.S. Geological Survey Scientific Investigations Report 2005-5272, 36 p.

Eastoe, C.J., 1978, A fluid inclusion study of the Panguna porphyry copper deposit, Bougainville, Papua New Guinea: Economic Geology, v. 73, p. 721-748.

Einaudi, M.T., Meinert, L.D., and Newberry, R.J., 1981, Skarn deposits: Society of Economic Geologists, 75th Anniversary Volume, p. 317-391.

Enders, M. S., Knickerbocker, C., Titley, S.R., and Southam, G., 2006, The role of bacteria in the supergene environment of the Morenci porphyry copper deposits, Greenlee County, Arizona. Economic Geology, v. 101, p. 59-70.

Eychaner, J.H., 1991, The Globe, Arizona, research site-Contaminants related to copper mining in a hydrologically integrated environment, in Mallard, G.E., and Aronson, D.A., eds., U.S. Geological Survey Toxic Substances Hydrology ProgramProceedings of the technical meeting, Monterey, California, March 11-15, 1991: U.S. Geological Survey Water-Resources Investigations Report 91-4034, p. 439-447.

Farmer, G.L., and DePaolo, D.J., 1984, Origin of Mesozoic and Tertiary granite in the western United States and implications for pre-Mesozoic crustal structure-2. $\mathrm{Nd}$ and $\mathrm{Sr}$ isotopic studies of unmineralized and $\mathrm{Cu}$ - and $\mathrm{Mo}$-mineralized granite in the Precambrian craton: Journal of Geophysical Research, v. 89, p. 10141-10160.

Ford, J.H., 1978, A chemical study of alteration at the Panguna porphyry copper deposit, Bougainville, Papua New Guinea: Economic Geology, v. 73, p. 703-720.

Ford, K., Keating, P., and Thomas, M.D., 2007, Overview of geophysical signatures associated with Canadian ore deposits in Goodfellow, W.D., ed., Mineral deposits of Canada-A synthesis paper of major deposit-types, district metallogeny, the evolution of geological provinces, and exploration methods: Geological Association of Canada, Mineral Deposits Division, Special Publication 5, p. 939-970.

Franchini, M., Impiccini, A., Meinert, L., Grathoff, G., and Schalamuk, I.B.A., 2007, Clay mineralogy and zonation in the Campana Mahuida porphyry $\mathrm{Cu}$ deposit, Neuquén, Argentina-Implications for porphyry Cu exploration: Economic Geology, v. 102, p. $27-54$.

Gammons, C.H., and Duaime, T.E., 2005, Long term changes in the limnology and geochemistry of the Berkeley pit lake, Butte, Montana: Mine Water and the Environment, v. 25, p. 76-85. 
Gammons, C.H., Metesh, J.J., and Duaime, T.E., 2005, An overview of the mining history and geology of Butte, Montana: Mine Water and the Environment, v. 25, p. 70-75.

Garrett, S., 1996, The geology and mineralization of the Dinkidi porphyry related Au-Cu deposit: Australian Mineral Foundation, Porphyry Related Copper and Gold Deposits of the Asia Pacific Region, conference proceedings, Cairns, Australia, $\mathrm{p}$. 6.1-6.15.

Garwin, S., 2002, The geologic setting of intrusion-related hydrothermal systems near the Batu Hijau porphyry copper-gold deposit, Sumbawa, Indonesia, in Goldfarb, R.J., and Nielsen, R.L., eds., Integrated methods for discovery—Global exploration in the twenty-first century: Society of Economic Geologists, Special Publication 9, p. 333-366.

Gettings, M., 2005, Magnetic mineralogy and models of magnetic susceptibility for altered rocks of the Stinkingwater porphyry, Wyoming, USA. Accessed at: http://www.cosis.net/abstracts/IAGA2005/00691/IAGA2005-A-00691.pdf

Gilluly, J., 1946, The Ajo mining district, Arizona: U.S. Geological Survey Professional Paper 209, 112 p.

Golovanov, I.M., Seltmann, R., and Kremenetsky, A.A., 2005, The porphyry Cu-Au/Mo deposits of central Eurasia-2. The Almalyk (Kal'makyr-Dalnee) and Saukbulak Cu-Au porphyry systems, Uzbekistan, in Porter, T.M., ed., Super porphyry copper \& gold deposits-A global perspective: Adelaide, PBC Publishing, v. 2, p. 513-523.

Govett, G.J.S., 1983, Rock geochemistry in mineral exploration-Handbook of exploration geochemistry, v. 3: New York, Elsevier, p. 181-225.

Gow, P.A., and Walshe, J.L., 2005, The Role of pre-existing geologic architecture in the formation of giant porphyry-related Cu +/- Au deposits-Examples from New Guinea and Chile: Economic Geology, v. 100, p. 819-833.

Green, R.O., Westwood, M.L., Sarture, C.M., Chrien, T.G., Aronsson, M., Chippendale, B.J., Faust, J.A., Pavri, B.E., Chovit, C.J., Solis, J., Olah, M.R., and Williams, O., 1998, Imaging spectroscopy and the Airborne Visible/Infrared Imaging Spectrometer (AVIRIS): Remote Sensing of Environment, v. 65, p. 227-248.

Guilbert, J.M., 1995, Geology, alteration, mineralization, and genesis of the Bajo de la Alumbrera porphyry copper-gold deposit, Catamarca Province, Argentina, in Pierce, F.W., and Bolm, J.G., eds., Porphyry copper deposits of the American Cordillera: Arizona Geological Society Digest 20, p. 646-656.

Gustafson, L.B., and Hunt, J.P., 1975, The porphyry copper deposit at El Salvador, Chile: Economic Geology, v. 70, p. 857-912.

Hansen, H.K., Yianatos, J.B., and Ottosen, L.M., 2005, Speciation and leachability of copper in mine tailings from porphyry copper mining-Influence of particle size: Chemosphere, v. 60, p. 1497-1503.

Harris, A.C., Kamenetsky, V.S., White, N.C., van Achterbergh, E., and Ryan, C.G., 2003, Silicate-melt inclusions in quartz veins_-Linking magmas and porphyry Cu deposits: Science, v. 302, p. 2109-2111.

Harris, A.C., Kamenetsky, V.S., White, N.C., and Steele, D.A., 2004, Volatile phase separation in silicic magmas at Bajo de la Alumbrera porphyry Cu-Au deposit, NW Argentina: Resource Geology, v. 54, p. 341-356.

Hartley, A.J., and Rice, C.M., 2005, Controls on supergene enrichment of porphyry copper deposits in the Central Andes-A review and discussion: Mineralium Deposita, v. 40, p. 515-525.

Haschke, M., Gunther, A., and Scheuber, E., 2002, Repeated crustal thickening and recycling during the Andean orogeny in north Chile $\left(21^{\circ}-26^{\circ} \mathrm{S}\right)$ : Journal of Geophysical Research, v. 107, ECV 6 1-18.

Hedenquist, J.W., and Richards, J.P., 1998, The influence of geochemical techniques on the development of genetic models for porphyry copper deposits: Reviews in Economic Geology, v. 10, p. 235-256. 
Heidrick, T.L., and Titley, 1982, Fracture and dike patterns in Laramide plutons and their structural and tectonic implications, in Titley, S.R., ed., Advances in geology of the porphyry copper deposits: Tucson, The University of Arizona Press, p. 73-91.

Heinrich, C.A., 2007, Fluid-fluid interactions in magmatic-hydrothermal ore formation: Reviews in Mineralogy \& Geochemistry, v. 65 , p. 363-387.

Heinrich, C.A., Gunther, D., Audetat, A., Ulrich, T., and Frischknecht, R., 1999, Metal fractionation between magmatic brine and vapor, determined by microanalysis of fluid inclusions: Geology, v. 27, p. 755-758.

Heithersay, P.S., and Walshe, J.L., 1995, Endeavour 26 North-A porphyry copper-gold deposit in the late Ordovician, shoshonitic Goonumbla volcanic complex, New South Wales, Australia: Economic Geology, v. 90, p. 1506-1532.

Hemley, J.J., and Hunt, J.P., 1992, Hydrothermal ore-forming processes in the light of studies in rock-buffered systems-II. Some general geologic applications: Economic Geology, v. 87, p. 23-43.

Henley, R.W., and McNabb, A., 1978, Magmatic vapor plumes and groundwater interaction in porphyry copper emplacement: Economic Geology, v. 73, p. 1-20.

Hezarkhani, A., 2006, Hydrothermal evolution of the Sar-Cheshmeh porphyry Cu-Mo deposit, Iran—Evidence from fluid inclusions: Journal of Asian Earth Sciences, v. 28, p. 409-422.

Hilldreth, W., and Moorbath, S., 1988, Crustal contributions to arc magmatism in the Andes of Central Chile: Contributions to Mineralogy and Petrology, v. 98, p. 455-489.

Hindle, D., and Kley, J., 2002, Displacements, strains and rotations in the Central Andean plate boundary zone, in Stein, S., and Freymueller, J.T., eds., Plate boundary zones: American Geophysical Union, Geodynamics Series, v. 30, p. 135-144.

Holliday, J.R., Wilson, A.J., Blevin, P.L., Tedder, I.J., Dunham, P.D., and Pfitzner, M., 2002, Porphyry gold-copper mineralization in the Cadia district, eastern Lachlan Fold Belt, New South Wales, and its relationship to shoshonitic magmatism: Mineralium Deposita, v. 37, p. 100-116.

Hollister, V.F., and Sirvas, E.B., 1974, The Michiquillay porphyry copper deposit: Mineralium Deposita, v. 9, p. 261-269.

Howell, W.J.S., Fardon, R.S.H., Carter, R.J., and Bumsted, E.D., 1978, History of the Ok Tedi porphyry copper prospect, Papua New Guinea-II. The years 1975 to 1978: Economic Geology, v. 73, p. 802-809.

Imai, A., Ohbuchi, Y., Tanaka, T., and Morita, S., 2007, Characteristics of porphyry Cu mineralization at Waisoi (Namosi District), Viti Levu, Fiji: Resource Geology, v. 57, p. 374-385.

Ishihara, S., 1981, The granitoid series and mineralization: Society of Economic Geologists, Economic Geology 75th Anniversary Volume, p. 458-484.

Jambor, J.L., and Owens, D.R., 1987, Vinciennite in the Maggie porphyry copper deposit, British Columbia: The Canadian Mineralogist, v. 25, p. 227-228.

Jensen, E.P., and Barton, M.D., 2000, Gold deposits related to alkaline magmatism: Reviews in Economic Geology, v. 13, p. $270-314$.

John, E.C., 1978, Mineral zones in the Utah Copper orebody: Economic Geology, v. 73, p. 1250-1259.

Jones, G.J., 1985, The Goonumbla porphyry copper deposits, New South Wales: Economic Geology, v. 80, p. 591-613.

Kay, S.M., Mpodozis, C., and Coira, B., 1999, Neogene magmatism, tectonism, and mineral deposits of the Central Andes $\left(22^{\circ}\right.$ to $33^{\circ} \mathrm{S}$ latitude): Society of Economic Geologists, Special Publication 7, p. 27-59. 
Kesler, S.E., 1973, Copper, molybdenum, and gold abundances in porphyry copper deposits: Economic Geology, v. 68, p. $106-112$.

Khashgerel, B-E., Rye, R.O., Hedenquist, J.W., and Kavlieris, I., 2006, Geology and reconnaissance stable isotope study of the Oyu Tolgoi porphyry Cu-Au system, south Gobi, Mongolia: Economic Geology, v. 101, p. 503-502.

Kirby, C.S., and Cravotta, C.A., III, 2005a, Net alkalinity and net acidity 1-Theoretical considerations: Applied Geochemistry, v. 20, p. 1920-1940.

Kirby, C.S, and Cravotta, C.A. III, 2005b, Net alkalinity and net acidity 2-Practical considerations: Applied Geochemistry, v. 20, p. 1941-1964.

Klemm, L.M., Pettke, T., and Heinrich, C.A., 2007, Hydrothermal evolution of the El Teniente deposit, Chile—Porphyry Cu-Mo ore deposition from low-salinity magmatic fluids: Economic Geology, v. 102, p. 1021-1045.

Klemm, L.M., Pettke, T., and Heinrich, C.A., 2008, Fluid and source magma evolution of the Questa porphyry Mo deposit, New Mexico, USA: Mineralium Deposita, v. 43, p. 533-552.

Landtwing, M.R., Pettke, T., Halter, W.E., Heinrich, C.A., Redmond, P.R., Einaudi, M.T., and Kunze, K., 2005, Copper deposition during quartz dissolution by cooling magmatic-hydrothermal fluids-The Bingham porphyry: Earth and Planetary Science Letters, v. 235, p. 229-243.

Lang, J.R., and Titley, S.R., 1998, Isotopic and geochemical characteristics of Laramide magmatic systems in Arizona and implications for the genesis of porphyry copper deposits: Economic Geology, v. 93, p. 138-170.

Langton, J.M., and Williams, S.A., 1982, Structural, petrological and mineralogical controls for the Dos Pobres orebody, in Titley, S.R., ed., Advances in geology of the porphyry copper deposits: Tucson, The University of Arizona Press, p. 335-352.

Learned, R.E., 1972, Gold, a useful pathfinder element in the search for porphyry copper deposits in Puerto Rico: Proceedings of the Fourth International Geochemical Exploration Symposium, London, April 17-20, 1972.

Leybourne, M.I., and Cameron, E.M., 2006, Composition of groundwaters associated with porphyry-Cu deposits, Atacama Desert, Chile-Elemental and isotopic constraints on water sources and water-rock reactions: Geochimica et Cosmochimica Acta, v. 70 , p. $1616-1635$.

Li, J-W., Zhao, X-F., Zhou, M-F., Vasconcelos, P., Ma, C-Q., Deng, X-D., Sérgio de Souza, Z., Zhao, Y-X., and Wu, G., 2008, Origin of the Tongshankou porphyry-skarn Cu-Mo deposit, eastern Yangtze craton, eastern China-Geochronological, geochemical, and Sr-Nd-Hf isotopic constraints: Mineralium Deposita, v. 43, p. 315-336.

Li, X., and Sasaki, M., 2007, Hydrothermal alteration and mineralization of Middle Jurassic Dexing porphyry Cu-Mo deposit, southeast China: Resource Geology, v. 57, p. 409-426.

Lind, C.J., Creasey, C.L., and Angeroth, C., 1998, In-situ alteration of minerals by acidic ground water resulting from mining activities—Preliminary evaluation of method: Journal of Geochemical Exploration, v. 64, p. 293-305.

Lowell, J.D., 1968, Geology of the Kalamazoo orebody, San Manuel district, Arizona: Economic Geology, v. 63, p. 645-654.

Lowell, J.D., and Guilbert, J.M., 1970, Lateral and vertical alteration-mineralization zoning in porphyry ore deposits: Economic Geology, v. 65, p. 373-408.

Lynch, A.J., Taylor, A., and Avendaño Varas, C., 1994, Solvent extraction boom in Latin America: Engineering and Mining Journal, December 1994, p. 18-21.

MacDonald, G.D., and Arnold, L.C., 1994, Geological and geochemical zoning of the Grasberg igneous complex, Irian Jaya, Indonesia: Journal of Geochemical Exploration, v. 50, p. 143-178. 
Mars, J.C., and Rowan, L.C., 2006, Regional mapping of phyllic- and argillic-altered rocks in the Zagros magmatic arc, Iran, using Advanced Spaceborne Thermal Emission and Reflection Radiometer (ASTER) data and logical operator algorithms: Geosphere, v. 2, p. 161-186, 2 plates.

Mathur, R., Ruiz, J., and Munizaga, F., 2000, Relationship between copper tonnage of Chilean base metal porphyry deposits and Os isotope ratios: Geology, v. 28, p. 555-558.

Meinert, L.D., Dipple, G.M., and Nicolescu, S., 2005, World skarn deposits: Society of Economic Geologists, Economic Geology 100th Anniversary Volume, p. 299-336.

Meldrum, S.J., Aquino, R.S., Gonzales, R.I., Burke, R.J., Suyadi, A., Irianto, B., and Clarke, D.S., 1994, The Batu Hijau porphyry copper-gold deposit, Sumbawa Island, Indonesia: Journal of Geochemical Exploration, v. 50, p. $203-220$.

Metz, R.A., and Rose, A.W., 1966, Geology of the Ray copper deposit, Ray, Arizona, in Titley, S.R., and Hicks, C.L., eds., Geology of the porphyry copper deposits, southwestern North America: Tucson, The University of Arizona Press, p. 177-188.

Meyer, C., and Hemley, J., 1967, Wall rock alteration, in Barnes, H.L., ed., Geochemistry of hydrothermal ore deposits: New York, Holt, Rinehart, and Winston, Inc., p. 166-235.

Milu, V., Milesi, J-P., Leroy, J.L., 2004, Rosia Poieni copper deposit, Apuseni Mountains, Romania-Advanced argillic overprint of a porphyry system: Mineralium Deposita, v. 39, p. 173-188.

Moolick, R.T., and Durek, J.J., 1966, The Morenci district, in Titley, S.R., and Hicks, C.L., eds., Geology of the porphyry copper deposits, southwestern North America: Tucson, The University of Arizona Press, p. 221-231.

Mote, T.I., Becker, T.A., Renne, P., and Brimhall, G.H., 2001, Chronology of exotic mineralization at El Salvador, Chile, by ${ }^{40} \mathrm{Ar} /{ }^{39} \mathrm{Ar}$ dating of copper wad and supergene alunite: Economic Geology, v. 96, p. 351-366.

Nielsen, R.L., 1968, Hypogene texture and mineral zoning in a copper-bearing granodiorite stock, Santa Rita, New Mexico: Economic Geology, v. 63, p. 37-50.

Ohmoto, H., and Rye, R.O., 1979, Isotopes of sulfur and carbon, in Barnes, H.L., ed., Geochemistry of hydrothermal ore deposits, 2d ed.: New York, John Wiley and Sons, p. 509-567.

Olade, M., and Fletcher, K., 1976, Distribution of sulphur, and sulphide-iron and copper in bedrock associated with porphyry copper deposits, Highland Valley, British Columbia: Journal of Geochemical Exploration, v. 5, p. 21-30.

Oldenburg, D.W., Li, Y., and Ellis, R.G., 1997, Inversion of geophysical data over a copper gold porphyry deposit-A case history for Mt. Milligan: Geophysics, v. 62, p. 1419-1431.

Osatenko, M.J., and Jones, M.B., 1976, Valley copper, in Brown, A.S., ed., Porphyry deposits of the Canadian Cordillera: Canadian Institute of Mining and Metallurgy, Special Volume 15, p. 130-143.

Ossandón C.,G., Fréraut C.,R., Gustafson, L.B., Lindsay, D.D., and Zentilli, M., 2001, Geology of the Chuquicamata mine-A progress report: Economic Geology, v. 96, p. 249-270.

Padilla-Garza, R.A., Titley, S.R., and Eastoe, C.J., 2004, Hypogene evolution of the Escondida porphyry copper deposit, Chile, in Sillitoe, R.H., Perrelló, J., and Vidal, C.E., eds., Andean metallogeny-New discoveries, concepts, and updates: Society of Economic Geologists, Special Publication 11, p. 141-165.

Panteleyev, A., 1995a, Porphyry Cu-Au-Alkalic, in Lefebure, D.V., and Ray, G.E., eds., Selected British Columbia Mineral Deposit Profiles, Volume 1, Metallics and Coal: British Columbia Ministry of Energy of Employment and Investment, Open File 1995-20, p. 83-86. 
Panteleyev, A., 1995b, Porphyry Cu+/-Mo+/-Au, in Lefebure, D.V., and Ray, G.E., eds., Selected British Columbia mineral deposit profiles, volume 1, Metallics and coal: British Columbia Ministry of Energy of Employment and Investment, Open File 1995-20, p. 87-92.

Perelló, J., Brockway, H., and Martini, R., 2004, Discovery and geology of the Esperanza porphyry copper-gold deposit, Antofagasta Region, northern Chile, in Sillitoe, R.H., Perrelló, J., and Vidal, C.E., eds., Andean metallogeny—New discoveries, concepts, and updates: Society of Economic Geologists, Special Publication 11, p. 167-186.

Peters, W.C., James, A.H., and Field, C.W., 1966, Geology of the Bingham Canyon porphyry copper deposit, Utah, in Titley, S.R., and Hicks, C.L., eds., Geology of the porphyry copper deposits, southwestern North America: Tucson, The University of Arizona Press, p. 165-175.

Peterson, N.P., Gilbert, C.M., and Quick. G.L., 1946, Hydrothermal alteration in the Castle Dome copper deposit, Arizona: Economic Geology, v. 41, p. 820-840.

Phillips, K.A., and Niemuth, N.J., 1993, The primary copper industry of Arizona in 1991: Arizona Department of Mines and Mineral Resources, Special Report 18, 53 p.

Plaza-Toledo, M., 2005, Natural rock drainage associated with unmined porphyry copper deposits in the Río Grande de Arecibo watershed, Puerto Rico: unpublished M.Sc. thesis, Mayagüez, University of Puerto Rico, 162 p.

Ramdohr, P., 1980, The ore minerals and their intergrowths—Volume 2: New York, Pergamon Press, p. 441-1205.

Ranjbar, H., Shahriari, H., and Honarmand, M., 2004, Proceedings volume, XXth ISPRS Congress, July 12-23, 2004, Istanbul, Turkey, 6 pages. Accessed at: http://www.isprs.org/istanbul2004/comm4/papers/438.pdf

Reyes, M., 1991, The Andacollo strata-bound gold deposit, Chile, and its position in a porphyry copper-gold system: Economic Geology, v. 86, p. 1301-1316.

Richard, K., and Courtright, J.H., 1966, Structure and mineralization at Silver Bell, Arizona, in Titley, S.R., and Hicks, C.L., eds., Geology of the porphyry copper deposits, southwestern North America: Tucson, The University of Arizona Press, p. $157-163$.

Richards, J.P., 2003, Tectono-magmatic precursors for geophysical data over a copper gold porphyry Cu-(Mo-Au) deposit formation: Economic Geology, v. 96 p. 1419-1431.

Richards, J.P., Boyce, A.J., and Pringle, M.S., 2001, Geological evolution of the Escondida area, northern Chile—A model for spatial and temporal localization of porphyry Cu mineralization: Economic Geology, v. 96, p. 271-305.

Roberts, S., 1975, Early hydrothermal alteration and mineralization in the Butte District, Montana: Harvard University, Cambridge, Massachusetts, Ph.D. thesis, 175 p.

Rose, A.W., 1970, Zonal relations of wallrock alteration and sulfide distribution at porphyry copper deposits: Economic Geology, v.65, p. 920-936.

Rose, A.W., and Baltosser, W.W., 1966, The porphyry copper deposit at Santa Rita, New Mexico, in Titley, S.R., and Hicks, C.L., eds., Geology of the porphyry copper deposits, southwestern North America: Tucson, The University of Arizona Press, p. 205-220.

Rowan, L.C., Hook, S.J., Abrams, M.J., and Mars, J.C., 2003, Mapping hydrothermally altered rocks at Cuprite, Nevada, using the advanced spaceborne thermal emission and reflection radiometer (ASTER)—A new satellite-imaging system: Economic Geology, v. 98, p. 1018-1027.

Rowan, L.C., Schmidt, R.G., and Mars, J.C., 2006, Distribution of hydrothermally altered rocks in the Reko Diq, Pakistan, mineralized area based on spectral analysis of ASTER data: Remote Sensing of Environment, v. 104, p. 74-87. 
Roy, B., and Clowes, R.M., 2000, Seismic and potential-field imaging of the Guichon Creek batholith, British Columbia, Canada, to delineate structures hosting porphyry copper deposits: Geophysics, v. 65, p. 1418-1434.

Ruiz, J., and Mathur, R., 1999, Metallogenesis in continental margins-Re-Os evidence from porphyry copper deposits in Chile: Reviews in Economic Geology, v. 12, p. 1-28.

Rusk, B.G., Reed, M.H., and Dilles, J.H., 2008, Fluid inclusion evidence for magmatic-hydrothermal fluid evolution in the porphyry copper-molybdenum deposit at Butte, Montana: Economic Geology, v. 103, p. 307-334.

Salisbury, J. W., Walter, L. W., and Vergo, N., 1987, Mid-Infrared (2.1-25um) Spectra of Minerals, First Edition: U.S. Geological Survey Open File Report 87-263.

Sandbak, L.A., and Alexander, G.H., 1995, Geology and rock mechanics of the Kalamazoo orebody, San Manuel, Arizona, in Pierce, F.W., and Bolm, J.G., eds., Porphyry copper deposits of the American Cordillera: Arizona Geological Society Digest 20, p. 396-423.

Sapiie, B., and Cloos, M., 2004, Strike-slip faulting in the core of the Central Range of West New Guinea—Ertsberg mining district, Indonesia: Geological Society of America Bulletin, v. 116, p. 277-293.

Schwartz, G.M., 1947, Hydrothermal alteration in the "porphyry copper" deposits: Economic Geology, v. 42, p. 319-352.

Schwartz, G.M., 1966, The nature of primary and secondary mineralization in porphyry copper deposits, in Titley, S.R., and Hicks, C.L., eds., Geology of the porphyry copper deposits, southwestern North America: Tucson, The University of Arizona Press, p. 41-50.

Seedorff, E., Dilles, J.H., Proffett, Jr., J.M., Einaudi, M.T., Zurcher, L., Stavast, W.J.A., Johnson, D.A., and Barton, M.D., 2005, Porphyry deposits-Characteristics and origin of hypogene features: Society of Economic Geologists, Economic Geology 100th Anniversary Volume, p. 251-298.

Shahabpour, J. 1999, The role of deep structures in the distribution of some major ore deposits in Iran, NE of the Zagros thrust zone: Journal of Geodynamics, v. 28, p. 237-250.

Shayestehfar, M. R., Ranjbar, H. and Ahmadi, O., 2005, Alteration mapping by using ETM+ and ASTER data in Dehaj area, southeast of Iran: Proceedings, Society of Photographic Instrumentation Engineers (SPIE), Belgium, September 19-20, 2005, SPIE-5983, p. 194-201.

Sheppard, S.M.F., Nielsen, R.L., and Taylor, H.P., Jr., 1969, Oxygen and hydrogen isotope ratios of clay minerals from porphyry copper deposits: Economic Geology, v. 64, p. 755-777.

Sheppard, S.M.F., and Gustafson, L.B., 1976, Oxygen and hydrogen isotopes in the porphyry copper deposit at El Salvador, Chile: Economic Geology, v. 71, p. 1549-1559.

Sillitoe, R.H., 1973, Geology of the Los Pelambres porphyry copper deposit, Chile: Economic Geology, v. 68, p. 1-10.

Sillitoe, R.H., 1979, Some thoughts on gold-rich porphyry copper deposits: Mineralium Deposita, v. 14, p. 161-174.

Sillitoe, R.H., 1993, Gold-rich porphyry copper deposits: Geological model and exploration implications: Geological Association of Canada Special Paper 40, p. 465-478.

Sillitoe, R.H., 1998, Epochs of intrusion-related copper mineralization in the Andes: Journal of South American Earth Sciences, v. 1, p. $89-108$.

Sillitoe, R.H., 2000, Gold-rich porphyry deposits-Descriptive and genetic models and their role in exploration and discovery: Reviews in Economic Geology, v. 13, p. 315-345. 
Sillitoe, R.H., 2005, Supergene oxidized and enriched porphyry copper and related deposits: Society of Economic Geologists, Economic Geology 100th Anniversary Volume, p. 723-768.

Sillitoe, R.H., and McKee, E.H., 1996, Age of supergene oxidation and enrichment in the Chilean porphyry copper province: Economic Geology, v. 91, p. 164-179.

Sillitoe, R.H., and Perelló, J., 2005, Andean copper province-Tectonomagmatic settings, deposit types, metallogeny, exploration, and discovery: Society of Economic Geologists, Economic Geology 100th Anniversary Volume, p. 845-890.

Simmons, W.W., and Fowells, J.E., 1966, Geology of the Copper Cities mine, in Titley, S.R., and Hicks, C.L., eds., Geology of the porphyry copper deposits, southwestern North America: Tucson, The University of Arizona Press, p. 151-156.

Sinclair, W.D., 1995, Porphyry Mo (Low F-Type), in Lefebure, D.V. and Ray, G.E., eds., Selected British Columbia mineral deposit profiles, Volume 1-Metallics and coal: British Columbia Ministry of Energy of Employment and Investment Open File 1995-20, p. 93-96.

Sinclair, W.D., 2007, Porphyry deposits, in Goodfellow, W.D., ed., Mineral deposits of Canada: Geological Association of Canada Special Publication 5, p. 223-243.

Singer, D.A., and Cox, D.P., 1986, Grade and tonnage model of porphyry Cu-Au, in Cox, D.P., and Singer, D.A., eds., Mineral deposit models: U.S. Geological Survey Bulletin 1693, p. 110-114.

Singer, D.A., Cox, D.P., and Mosier, D.L., 1986, Grade and tonnage model of porphyry Cu-Mo, in Cox, D.P., and Singer, D.A., eds., Mineral deposit models: U.S. Geological Survey Bulletin 1693, p. 116-119.

Singer, D.A., Berger, V.I., and Moring, B.C., 2008, Porphyry copper deposits of the world-Database and grade and tonnage models: U.S. Geological Survey Open-File Report 2008-1155. Accessed at: http://pubs.usgs.gov/of/2008/1 155/

Stanley, C.R., Holbek, P.M., Huyck, H.L.O., Lang, J.R., Preto, V.A.G., Blower, S.J., and Bottaro, J.C., 1995, Geology of the Copper Mountain alkalic copper-gold porphyry deposits, Princeton, British Columbia, in Schroeter, T.G., ed., Porphyry deposits of the northwestern Cordillera of North America: Geological Society of the Canadian Institute of Mines Special Volume 46, p. 537-564.

Stern, C.R., Funk, J.A., and Skewes, M.A., 2007, Magmatic anhydrite in plutonic rocks at the El Teniente Cu-Mo deposit, Chile, and the role of sulfur- and copper-rich magmas in its formation: Economic Geology, v. 102, p. 1335-1344.

Stollenwerk, K.G., 1994, Geochemical interactions between constituents in acidic ground water and alluvium in an aquifer near Globe, Arizona: Applied Geochemistry, v. 9, p. 353-369.

Suerte, L.O., Nishihara, S., Imai, A., Watanabe, K., Yumul, G.P., Jr., and Maglambayan, V.B., 2007, Occurrences of ore minerals and fluid inclusion study on the Kingking porphyry copper-gold deposit, eastern Mindanao, Philippines: Resource Geology, v. 57, p. 219-229.

Sutherland Brown, A., 1976, Morphology and classification, in Sutherland Brown, A., ed., Porphyry deposits of the Canadian Cordillera: Canadian Institute of Mining and Metallurgy, Special Volume 15, p. 44-51.

Taghipour, N., Aftabi, A., and Mathur, R., 2008, Geology and Re-Os geochronology of mineralization of the Miduk porphyry copper deposit, Iran: Resource Geology, v. 58, p. 143-160.

Thomas, L.A., 1966, Geology of the San Manuel ore body, in Titley, S.R., and Hicks, C.L., eds., Geology of the porphyry copper deposits, southwestern North America: Tucson, The University of Arizona Press, p. 133-142.

Titley, S.R., 1982, The style and progress of mineralization and alteration in porphyry copper systems, in Titley, S.R., ed., Advances in geology of the porphyry copper deposits: Tucson, The University of Arizona Press, p. 93-116. 
Titley, S.R., 1993, Characteristics of porphyry copper occurrence in the American Southwest: Geological Association of Canada Special Paper 40, p. 433-464.

Tosdal, R.M., Wooden, J.L., and Bouse, R.M., 1999, Pb isotopes, ore deposits, and metallogenic terranes: Society of Economic Geologists, Reviews in Economic Geology, v. 12, p. 1-12.

Tosdal, R.M., and Richards, J.P., 2001, Magmatic and structural controls on the development of porphyry $\mathrm{Cu} \pm \mathrm{Mo} \pm \mathrm{Au}$ deposits: Society of Economic Geologists, Reviews in Economic Geology, v. 14, p. 157-181.

Ulrich, T., Gunther, D., and Heinrich, C.A., 1999, Gold concentrations of magmatic brines and the metal budget of porphyry copper deposits: Nature, v. 399, p. 676-679.

Ulrich, T., Gunther, D., and Heinrich, C.A., 2001, The evolution of a porphyry Cu-Au deposit, based on LA-ICPMS analysis of fluid inclusions: Bajo de la Alumbrera, Argentina: Economic Geology, v. 96, p. 1743-1774.

Vargas, R., Gustafson, L.B., Vukasovic, M., Tidy, E., and Skewes, A., 1999, Ore breccias in the Rio Blanco-Los Bronces porphyry copper deposit, Chile: Society of Economic Geologists, Special Publication 7, p. 281-297.

Velasco, J.R., 1966, Geology of the Cananea district, in Titley, S.R., and Hicks, C.L., eds., Geology of the porphyry copper deposits, southwestern North America: Tucson, The University of Arizona Press, p. 245-249.

Warnaars, F.W., Holmgren D.,C., and Barassi F.S., 1985, Porphyry copper and tourmaline breccias at Los Bronces-Rio Blanco, Chile: Economic Geology, v. 80, p. 1544-1565.

Watanabe, Y., and Hedenquist, J.W., 2001, Mineralogic and stable isotope zonation at the surface over the El Salvador porphyry copper deposit, Chile: Economic Geology, v. 96, p. 1775-1797.

Waterman, G.C., and Hamilton, R.L., 1975, The Sar Cheshmeh porphyry copper deposit: Economic Geology, v. 70, p. 568-576.

West, R.J., and Aiken, D.M., 1982, Geology of the Sierrita-Esperanza deposit, in Titley, S.R., ed., Advances in geology of the porphyry copper deposits: Tucson, The University of Arizona Press, p. 433-465.

White, A.J.R., 2004, Porphyry copper mineralization of western USA, in Blevin, P.H., Jones, M., and Chappell, B.W., eds., Magmas to mineralization, The Ishihara Symposium, Granites and associated metallogenesis: Geoscience Australia, p. $139-140$.

Williams-Jones, A.E., and Heinrich, C.A., 2005, Vapor transport of metals and the formation of magmatic-hydrothermal ore deposits: Economic Geology, v. 100, p. 1287-1312.

Wilson, A.J., Cooke, D.R., Stein, H.J., Fanning, C.M., Holliday, J.R., and Tedder, I.J., 2007, U-Pb and Re-Os geochronologic evidence for two alkalic porphyry ore-forming events in the Cadia district, New South Wales, Australia: Economic Geology, v. 102 , p. $3-26$.

Wilson, J.C., 1975, Ore-magma relation in a late-stage dike, in Bray, R.E., and Wilson, J.C., eds., Guidebook to the Bingham mining district: Society of Economic Geologists, Bingham Canyon, Utah, October 23, 1975, p. 99-103.

Wooden, J.L., Stacey, J.S., Howard, K.A., Doe, B.R., and Miller, D.M., 1988, Lead isotopic evidence for the formation of Proterozoic crust in the southwestern United States, in Ernst, W.G., ed., Metamorphism and crustal evolution, western conterminous United States, Rubey Volume 7: Engelwood Cliffs, New Jersey, Prentice-Hall, p. 68-86.

Zonge, K.L., and Wynn, J.C., 1975, Recent advances and applications in complex resistivity measurements: Geophysics, v. 40, p. 851-864.

Zonge, K.L., Wynn, J.C., and Urquhart, S.A., 2005, Resistivity, induced polarization, and complex resistivity: Society of Exploration Geophysicists Special Volume on Near Surface Geophysics, p. 265-300. 
Zweng, P.L., and Clark, A.H., 1995, Hypogene evolution of the Toquepala porphyry copper-molybdenum deposit, Moquegua, southeastern Peru, in Pierce, F.W., and Bolm, J.G., eds., Porphyry copper deposits of the American Cordillera: Arizona Geological Society Digest 20, p. 566-612.

\section{Appendix}

It has been recognized for many years that there is variation between porphyry copper deposits regarding the content and concentrations of by-product metals in individual deposits including molybdenum and gold. In the course of constructing grade and tonnage models of porphyry copper deposits by the U.S. Geological Survey, it was found that porphyry copper deposits should be subdivided into three subclasses - copper, copper-molybdenum, and copper-gold—owing to their having statistically different grade and tonnage distributions (see Singer and others, 1986; Singer and Cox, 1986). The first subclass, copper, is referred to as the "general model" because it includes the deposits in the other two subclasses. Cox and Singer (1988) further evaluated the distribution of gold in 55 porphyry copper deposits for which grade and tonnage data were available. Although Cox and Singer (1988) found there to be a continuum in copper, molybdenum, and gold contents between the deposits in their study, they defined three subtypes as follows: copper-gold, copper-gold-molybdenum, and copper-molybdenum. They defined the subtypes on the basis of the gold:molybdenum ratio. Porphyry copper-gold deposits have gold:molybdenum ratios $\geq 30$, copper-gold-molybdenum deposits have gold:molybdenum ratios greater than 3, but less than 30, and copper-molybdenum deposits have gold:molybdenum ratios $\leq 3$.

A number of studies have suggested linkages between the by-product content of porphyry copper deposits and different geological attributes. Kesler (1973) recognized two types of deposits, copper-molybdenum and copper-gold, and concluded that copper-gold deposits are smaller as a group than copper-molybdenum deposits. He also determined that the differences may be explainable by primary compositional differences between mineralizing systems or different chemical responses to distinct geologic features such as the level of granitoid emplacement, permeability of the wall rocks, or wall-rock chemistry. Sillitoe (1979), defining gold-rich as deposits averaging greater than 0.4 gram gold per ton, concluded that high gold contents are not directly related to tectonic setting, host-rock composition, wall-rock composition, deposit age, level of erosion, orebody size, and presence or absence of phyllic alteration. Sillitoe (1979) did note that gold occurs in the potassic alteration zone in deposits with a high magnetite content. He also suggested that copper-poor, gold-rich deposits should exist. Sillitoe (1993) revisited the subject of gold-rich porphyry copper deposits and concluded that gold-rich deposits do not possess any unique features to distinguish them from copper-molybdenum deposits. Sillitoe (1993) found that 80 percent of the 29 deposits he studied have greater magnetite contents than non-gold-rich varieties. He also noted that calc-silicate alteration minerals, including amphibole, pyroxene, and(or) garnet, tend to occur in gold-rich varieties. Both copper-molybdenum and copper-gold deposits occur with calc-alkaline intrusive complexes, but only gold-rich deposits occur in alkalic intrusive complexes. However, those deposits with the most gold occur with calc-alkalic rocks rather than alkalic rock complexes (Sillitoe, 1993). 
Table 1. Intrusive rock compositions associated with selected porphyry copper deposits.

\begin{tabular}{|c|c|c|}
\hline Deposit & Intrusive rock types & Reference \\
\hline Batu Hijau, Indonesia & $\begin{array}{l}\text { Hornblende-plagioclase andesite, plagioclase } \\
\text { andesite, pyroxene-plagioclase andesite, hornblende } \\
\text { diorite, quartz diorite, granodiorite, tonalite, diorite, } \\
\text { porphyritic hornblende tonalite, porphyritic dacite, } \\
\text { tonalite porphyry }\end{array}$ & Garwin (2002) \\
\hline Bingham, Utah, USA & $\begin{array}{l}\text { Monzonite, quartz monzonite porphyry, latite } \\
\text { porphyry, quartz latite porphyry }\end{array}$ & Babcock and others (1995) \\
\hline $\begin{array}{l}\text { Cadia, New South Wales, } \\
\text { Australia }\end{array}$ & $\begin{array}{l}\text { Monzodiorite, diorite, gabbro, quartz monzonite } \\
\text { porphyry, monzonite, latite, trachyte, basalt, basaltic } \\
\text { andesite }\end{array}$ & Holliday and others (2002) \\
\hline Chuquicamata, Chile & Granodiorite & Ossandón and others (2001) \\
\hline $\begin{array}{l}\text { Copper Mountain, } \\
\text { British Columbia, Canada }\end{array}$ & Diorite, monzonite, syenite, monzodiorite & Stanley and others (1995) \\
\hline Dexing, Jiangxi, China & $\begin{array}{l}\text { Diorite porphyry, granodiorite porphyry, gabbro, } \\
\text { diabase }\end{array}$ & Singer and others (2008) \\
\hline Dinkidi, Philippines & $\begin{array}{l}\text { Diorite, monzonite porphyry, monzonite, quartz } \\
\text { monzonite porphyry, syenite }\end{array}$ & Garrett (1996) \\
\hline Elatsite, Bulgaria & $\begin{array}{l}\text { Diorite porphyry, granodiorite porphyry, monzonite } \\
\text { porphyry, quartz diorite porphyry, syenite porphyry, } \\
\text { aplite }\end{array}$ & Singer and others (2008) \\
\hline El Teniente, Chile & Quartz diorite, tonalite, microdiorite, andesite & $\begin{array}{l}\text { Klemm and others (2007) } \\
\text { Stern and others (2007) }\end{array}$ \\
\hline Escondida, Chile & Quartz monzonite, granodiorite & Padilla-Garza and others (2004) \\
\hline Grasberg, Indonesia & $\begin{array}{l}\text { Andesite, diorite porphyry, monzodiorite porphyry, } \\
\text { hornblende monzonite porphyry }\end{array}$ & MacDonald and Arnold (1994) \\
\hline Kounrad, Kazakhstan & $\begin{array}{l}\text { Diorite porphyry, granodiorite, granodiorite } \\
\text { porphyry, quartz diorite porphyry, trondhjemite }\end{array}$ & Singer and others (2008) \\
\hline $\begin{array}{l}\text { Los Bronces-Rio Blanco, } \\
\text { Chile }\end{array}$ & $\begin{array}{l}\text { Quartz monzonite, quartz monzodiorite, } \\
\text { granodiorite, hornblende diorite, syenite, aplite, } \\
\text { dacite porphyry, quartz latite, tonalite porphyry }\end{array}$ & $\begin{array}{l}\text { Warnaars and others (1985) } \\
\text { Deckart and others (2005) }\end{array}$ \\
\hline Los Pelambres, Chile & Tonalite, tonalite porphyry & Sillitoe (1973) \\
\hline Michiquillay, Peru & Quartz monzonite, porphyritic granodiorite & Hollister and Sirvas (1974) \\
\hline Morenci, Arizona, USA & $\begin{array}{l}\text { Diorite porphyry, diorite porphyry, quartz monzonite } \\
\text { porphyry, diabase }\end{array}$ & Moolick and Durek (1966) \\
\hline Rosia Poieni, Romania & Hornblende andesite, microdiorite & Milu and others (2004) \\
\hline Sar Cheshmeh, Iran & $\begin{array}{l}\text { Granodiorite porphyry, granodiorite, diorite, dacite } \\
\text { porphyry, andesite }\end{array}$ & $\begin{array}{l}\text { Waterman and Hamilton (1975) } \\
\text { Hezarkhani (2006) }\end{array}$ \\
\hline
\end{tabular}


Table 2. Major and minor axes of extent of altered rock, orebodies, and sulfide-bearing rock in kilometers together with the total area of altered rock, ore, and sulfide-bearing area, in square kilometers for selected deposits, worldwide. The shortest dimension (minor axis) is measured by the distance between parallel lines that just touch the object. The major axis is measured to the ends of the object on a line perpendicular to the short axis. Areas are calculated assuming an elliptical object in plan view. The deposits are organized alphabetically by country. Dashed lines indicate no data available. (After Singer and others, 2008).

\begin{tabular}{|c|c|c|c|c|c|c|c|c|c|}
\hline Deposit & $\begin{array}{c}\text { Alteration } \\
\text { (major } \\
\text { axis) }\end{array}$ & $\begin{array}{l}\text { Alteration } \\
\text { (minor axis }\end{array}$ & $\begin{array}{c}\text { Altered } \\
\text { area }\end{array}$ & $\begin{array}{c}\text { Ore } \\
\text { (major } \\
\text { axis) }\end{array}$ & $\begin{array}{c}\text { Ore } \\
\text { (minor } \\
\text { axis) }\end{array}$ & $\begin{array}{l}\text { Ore } \\
\text { area }\end{array}$ & $\begin{array}{c}\text { Sulfides } \\
\text { (major axis) }\end{array}$ & $\begin{array}{c}\text { Sulfides } \\
\text { (minor axis) }\end{array}$ & $\begin{array}{c}\text { Sulfide } \\
\text { area }\end{array}$ \\
\hline Agua Rica, Argentina & 4.4 & 3.8 & 13.1 & 13.1 & -- & -- & -- & -- & -- \\
\hline $\begin{array}{l}\text { Bajo de la Alumbrera, } \\
\text { Argentina }\end{array}$ & 2.5 & 1.75 & 3.4 & 1.1 & 0.6 & 0.52 & -- & -- & -- \\
\hline Los Azules, Argentina & 5 & 8 & 31.4 & 3.3 & 0.9 & 2.3 & -- & -- & -- \\
\hline San Jorge, Armenia & -- & -- & -- & 0.8 & 0.4 & 0.25 & -- & -- & -- \\
\hline Agarak, Armenia & -- & -- & -- & 0.7 & 0.25 & 0.14 & -- & -- & -- \\
\hline $\begin{array}{l}\text { Cadia Hill/Ridgeway, } \\
\text { Australia }\end{array}$ & 7 & 3 & 16.5 & 1.0 & 0.35 & 0.27 & 3.5 & 1.6 & 4.4 \\
\hline Coalstoun, Australia & 1.8 & 0.8 & 1.1 & 0.45 & 0.2 & 0.07 & 1.2 & 0.7 & 0.66 \\
\hline Coppin Gap, Australia & -- & -- & -- & 1 & 0.5 & 0.39 & -- & -- & -- \\
\hline Endeavour, Australia & 6.5 & 3.7 & 19 & 1.7 & 0.96 & 1.3 & -- & -- & -- \\
\hline Mount Cannindah, Australia & -- & -- & -- & 1.7 & 0.96 & 1.3 & -- & -- & -- \\
\hline Peak Hill, Australia & 3.3 & 0.6 & 1.6 & -- & -- & -- & -- & -- & -- \\
\hline Yeoval, Azerbaijan & -- & -- & -- & 0.5 & 0.3 & 0.12 & -- & -- & -- \\
\hline Yeppon, Azerbaijan & -- & -- & -- & 0.9 & 0.35 & 0.25 & -- & -- & -- \\
\hline Chapada, Brazil & -- & -- & -- & 2.7 & 0.7 & 1.5 & -- & -- & -- \\
\hline Assarel, Bulgaria & 2.8 & 1 & 2.2 & -- & -- & -- & -- & -- & -- \\
\hline Elatsite, Bulgaria & -- & -- & -- & 1 & 0.6 & 0.47 & -- & -- & -- \\
\hline Medet, Bulgaria & -- & -- & -- & 1 & 0.4 & 0.31 & -- & -- & -- \\
\hline
\end{tabular}


Table 2. Major and minor axes of extent of altered rock, orebodies, and sulfide-bearing rock in kilometers together with the total area of altered rock, ore, and sulfide-bearing area, in square kilometers for selected deposits, worldwide. The shortest dimension (minor axis) is measured by the distance between parallel lines that just touch the object. The major axis is measured to the ends of the object on a line perpendicular to the short axis. Areas are calculated assuming an elliptical object in plan view. The deposits are organized alphabetically by country. Dashed lines indicate no data available. (After Singer and others, 2008).-Continued

\begin{tabular}{|c|c|c|c|c|c|c|c|c|c|}
\hline Deposit & $\begin{array}{c}\text { Alteration } \\
\text { (major } \\
\text { axis) }\end{array}$ & $\begin{array}{l}\text { Alteration } \\
\text { (minor axis }\end{array}$ & $\begin{array}{c}\text { Altered } \\
\text { area }\end{array}$ & $\begin{array}{c}\text { Ore } \\
\text { (major } \\
\text { axis) }\end{array}$ & $\begin{array}{c}\text { Ore } \\
\text { (minor } \\
\text { axis) }\end{array}$ & $\begin{array}{l}\text { Ore } \\
\text { area }\end{array}$ & $\begin{array}{c}\text { Sulfides } \\
\text { (major axis) }\end{array}$ & $\begin{array}{c}\text { Sulfides } \\
\text { (minor axis) }\end{array}$ & $\begin{array}{c}\text { Sulfide } \\
\text { area }\end{array}$ \\
\hline Ajax, Canada & -- & -- & -- & 0.42 & 0.15 & 0.05 & -- & -- & -- \\
\hline Bell Copper, Canada & 3.2 & 2.6 & 6.5 & 0.63 & 0.43 & 0.21 & 2.1 & 2 & 3.3 \\
\hline Berg, Canada & -- & -- & -- & 1.8 & 1.7 & 2.4 & 2.4 & 1.9 & 3.5 \\
\hline Bethlehem, Canada & -- & -- & -- & -- & -- & -- & 1.8 & 1.4 & 1.9 \\
\hline Big Onion, Canada & -- & -- & -- & 1.9 & 0.35 & 0.65 & -- & -- & -- \\
\hline Brenda, Canada & -- & -- & -- & 0.92 & 0.48 & 0.35 & 3.2 & 2.4 & 6 \\
\hline Casino, Canada & -- & -- & -- & 1.8 & 0.76 & 1.1 & 2.4 & 1.4 & 2.7 \\
\hline Copper Mountain, Canada & -- & -- & -- & 4.3 & 1.1 & 3.7 & 6 & 3 & 14 \\
\hline Don Rouyn, Canada & -- & -- & -- & 0.5 & 0.2 & 0.08 & -- & -- & -- \\
\hline Dorothy, Canada & 2.3 & 1.8 & 3.3 & 0.5 & 0.3 & 0.1 & 1.6 & 1.2 & 1.5 \\
\hline Fish Lake, Canada & -- & -- & -- & 1.6 & 0.8 & 0.97 & 3.6 & 2.5 & 7.1 \\
\hline Galore Creek, Canada & -- & -- & -- & 1.9 & 0.5 & 0.75 & 5 & 4 & 16 \\
\hline Gambier Island, Canada & -- & -- & -- & 1.1 & 0.6 & 0.52 & -- & -- & -- \\
\hline Gaspé, Canada & 9 & 5 & 7.5 & 0.6 & 0.3 & 0.14 & 2.5 & 1.1 & 2.2 \\
\hline Granisle, Canada & 3.2 & 2.2 & 5.6 & 0.7 & 0.3 & 0.16 & -- & -- & -- \\
\hline Highmont, Canada & -- & -- & -- & 1.1 & 0.73 & 0.64 & -- & -- & -- \\
\hline Huckleberry, Canada & 5 & 2.5 & 9.8 & 1 & 0.3 & 0.24 & 3.9 & 1.5 & 1.4 \\
\hline Hushamu, Canada & 6 & 3 & 5 & 1.8 & 0.9 & 1.3 & -- & -- & -- \\
\hline
\end{tabular}


Table 2. Major and minor axes of extent of altered rock, orebodies, and sulfide-bearing rock in kilometers together with the total area of altered rock, ore, and sulfide-bearing area, in square kilometers for selected deposits, worldwide. The shortest dimension (minor axis) is measured by the distance between parallel lines that just touch the object. The major axis is measured to the ends of the object on a line perpendicular to the short axis. Areas are calculated assuming an elliptical object in plan view. The deposits are organized alphabetically by country. Dashed lines indicate no data available. (After Singer and others, 2008).-Continued

\begin{tabular}{|c|c|c|c|c|c|c|c|c|c|}
\hline Deposit & $\begin{array}{c}\text { Alteration } \\
\text { (major } \\
\text { axis) }\end{array}$ & $\begin{array}{l}\text { Alteration } \\
\text { (minor axis }\end{array}$ & $\begin{array}{c}\text { Altered } \\
\text { area }\end{array}$ & $\begin{array}{c}\text { Ore } \\
\text { (major } \\
\text { axis) }\end{array}$ & $\begin{array}{c}\text { Ore } \\
\text { (minor } \\
\text { axis) }\end{array}$ & $\begin{array}{l}\text { Ore } \\
\text { area }\end{array}$ & $\begin{array}{c}\text { Sulfides } \\
\text { (major axis) }\end{array}$ & $\begin{array}{c}\text { Sulfides } \\
\text { (minor axis) }\end{array}$ & $\begin{array}{c}\text { Sulfide } \\
\text { area }\end{array}$ \\
\hline Island Copper, Canada & 5.2 & 1.1 & 4.9 & 2 & 0.52 & 0.31 & 2.2 & 1 & 1.7 \\
\hline Kemess North, Canada & 6.7 & 2.6 & 14 & 1.2 & 0.6 & 0.57 & -- & -- & -- \\
\hline Kemess South, Canada & -- & -- & -- & 1.7 & 0.75 & 1 & -- & -- & -- \\
\hline Lornex, Canada & -- & -- & -- & 1.9 & 1.1 & 1.3 & -- & -- & -- \\
\hline Louise Lake, Canada & 4 & 1 & 3.1 & 0.85 & 0.35 & 0.23 & -- & -- & -- \\
\hline Maggie, Canada & -- & -- & -- & 1.1 & 0.33 & 0.26 & 3.7 & 1.5 & 4.4 \\
\hline McIntyre, Canada & 2.5 & 0.5 & 0.98 & 0.5 & 0.13 & 0.05 & -- & -- & -- \\
\hline Morrison, Canada & -- & -- & -- & 1.5 & 0.7 & 0.82 & 2.8 & 2.3 & 5.1 \\
\hline Ox Lake, Canada & 1.3 & 1.3 & 1.3 & 0.7 & 0.5 & 0.27 & 1 & 0.8 & 0.63 \\
\hline Poison Mountain, Canada & -- & -- & -- & 1.5 & 0.8 & 0.94 & 1.7 & 1 & 1.3 \\
\hline Red Chris, Canada & 5 & 1.5 & 5.9 & 1.4 & 0.5 & 0.55 & -- & -- & -- \\
\hline Schaft Creek, Canada & 3.1 & 1.3 & 3.1 & 2.5 & 1.1 & 2.2 & -- & -- & -- \\
\hline Sulphurets, Canada & 6 & 3 & 14 & 1.8 & 0.9 & 1.3 & 4 & 1.8 & 5.6 \\
\hline Valley, Canada & -- & -- & -- & 1.8 & 1.2 & 1.7 & 6.5 & 4 & 20.4 \\
\hline Willa, Canada & -- & -- & -- & 0.5 & 0.15 & 0.06 & -- & -- & -- \\
\hline Andacollo, Chile & 5 & 3.8 & 15 & 1.5 & 1.3 & 1.5 & 5 & 2.5 & 9.8 \\
\hline Chuquicamata, Chile & -- & -- & -- & 12 & 3 & 28 & -- & -- & -- \\
\hline Collahuasi, Chile & 7 & 4.7 & 26 & 1.9 & 1.2 & 1.8 & -- & -- & -- \\
\hline
\end{tabular}


Table 2. Major and minor axes of extent of altered rock, orebodies, and sulfide-bearing rock in kilometers together with the total area of altered rock, ore, and sulfide-bearing area, in square kilometers for selected deposits, worldwide. The shortest dimension (minor axis) is measured by the distance between parallel lines that just touch the object. The major axis is measured to the ends of the object on a line perpendicular to the short axis. Areas are calculated assuming an elliptical object in plan view. The deposits are organized alphabetically by country. Dashed lines indicate no data available. (After Singer and others, 2008).-Continued

\begin{tabular}{|c|c|c|c|c|c|c|c|c|c|}
\hline Deposit & $\begin{array}{c}\text { Alteration } \\
\text { (major } \\
\text { axis) }\end{array}$ & $\begin{array}{l}\text { Alteration } \\
\text { (minor axis }\end{array}$ & $\begin{array}{c}\text { Altered } \\
\text { area }\end{array}$ & $\begin{array}{c}\text { Ore } \\
\text { (major } \\
\text { axis) }\end{array}$ & $\begin{array}{c}\text { Ore } \\
\text { (minor } \\
\text { axis) }\end{array}$ & $\begin{array}{l}\text { Ore } \\
\text { area }\end{array}$ & $\begin{array}{c}\text { Sulfides } \\
\text { (major axis) }\end{array}$ & $\begin{array}{c}\text { Sulfides } \\
\text { (minor axis) }\end{array}$ & $\begin{array}{c}\text { Sulfide } \\
\text { area }\end{array}$ \\
\hline El Abra, Chile & -- & -- & -- & 1.7 & 1.2 & 1.6 & 4.4 & 2.3 & 8 \\
\hline El Salvador, Chile & 8 & 5 & 31 & 1.8 & 1 & 1.4 & 3 & 3 & 7.1 \\
\hline El Teniente, Chile & -- & -- & -- & 2.7 & 2 & 4.2 & 4 & 3.5 & 11 \\
\hline Escondida, Chile & 11 & 9 & 78 & 4.5 & 1.6 & 5.7 & -- & -- & -- \\
\hline Lomas Bayas, Chile & -- & -- & -- & 1.6 & 1.3 & 1.6 & -- & -- & -- \\
\hline $\begin{array}{l}\text { Los Bronces/Rio Blanco, } \\
\text { Chile }\end{array}$ & -- & -- & -- & 5 & 2.8 & 11 & 11 & 5 & 43 \\
\hline Los Pelambres, Chile & 6.5 & 4.6 & 24 & 1.6 & 0.5 & 0.6 & 6.5 & 2.5 & 13 \\
\hline Potrerillos, Chile & -- & -- & -- & 1.5 & 0.76 & 0.91 & 6 & 4 & 19 \\
\hline Chengmenshan, China & -- & -- & -- & 0.8 & 0.6 & 0.4 & -- & -- & -- \\
\hline Dexing, China & 7.5 & 2 & 12 & 1.1 & 0.9 & 0.74 & -- & -- & -- \\
\hline Kalatage, China & -- & -- & -- & 0.6 & 0.04 & 0.02 & -- & -- & -- \\
\hline Malasongduo, China & -- & -- & -- & 0.95 & 0.8 & 0.6 & -- & -- & -- \\
\hline Mangzhong, China & -- & -- & -- & 1.1 & 0.25 & 0.22 & -- & -- & -- \\
\hline Nanmu, China & 2.8 & 0.9 & 2 & 1.2 & 0.3 & 0.3 & -- & -- & -- \\
\hline Tinggong, China & -- & -- & -- & 1.4 & 0.6 & 0.7 & -- & -- & -- \\
\hline Tuwu, China & 3 & 0.4 & 0.9 & 2.3 & 0.4 & 0.4 & -- & -- & -- \\
\hline Xietongmen, China & -- & -- & -- & 0.9 & 0.3 & 0.2 & -- & -- & -- \\
\hline Xifanping, China & 1.5 & 0.8 & 0.9 & 0.7 & 0.4 & 0.2 & -- & -- & -- \\
\hline
\end{tabular}


Table 2. Major and minor axes of extent of altered rock, orebodies, and sulfide-bearing rock in kilometers together with the total area of altered rock, ore, and sulfide-bearing area, in square kilometers for selected deposits, worldwide. The shortest dimension (minor axis) is measured by the distance between parallel lines that just touch the object. The major axis is measured to the ends of the object on a line perpendicular to the short axis. Areas are calculated assuming an elliptical object in plan view. The deposits are organized alphabetically by country. Dashed lines indicate no data available. (After Singer and others, 2008).-Continued

\begin{tabular}{|c|c|c|c|c|c|c|c|c|c|}
\hline Deposit & $\begin{array}{l}\text { Alteration } \\
\text { (major } \\
\text { axis) }\end{array}$ & $\begin{array}{l}\text { Alteration } \\
\text { (minor axis }\end{array}$ & $\begin{array}{c}\text { Altered } \\
\text { area }\end{array}$ & $\begin{array}{c}\text { Ore } \\
\text { (major } \\
\text { axis) }\end{array}$ & $\begin{array}{c}\text { Ore } \\
\text { (minor } \\
\text { axis) }\end{array}$ & $\begin{array}{l}\text { Ore } \\
\text { area }\end{array}$ & $\begin{array}{c}\text { Sulfides } \\
\text { (major axis) }\end{array}$ & $\begin{array}{c}\text { Sulfides } \\
\text { (minor axis) }\end{array}$ & $\begin{array}{c}\text { Sulfide } \\
\text { area }\end{array}$ \\
\hline Yandong, China & -- & -- & -- & 0.9 & 0.2 & 0.14 & -- & -- & -- \\
\hline Yulong, China & 2 & 1.5 & 2.4 & 1 & 0.8 & 0.6 & -- & -- & -- \\
\hline Zijinshan, China & -- & -- & -- & 0.83 & 0.5 & 0.32 & -- & -- & -- \\
\hline El Cobre, Cuba & -- & -- & -- & 1.8 & 0.7 & 0.99 & -- & -- & -- \\
\hline Chaucha, Ecuador & -- & -- & -- & 3.3 & 0.95 & 2.5 & 6.8 & 2.9 & 16 \\
\hline Cumay, Ecuador & -- & -- & -- & 1.5 & 0.75 & 0.88 & 3.5 & 1.5 & 4.1 \\
\hline Gaby-Papa Grande, Ecuador & -- & -- & -- & 0.9 & 0.1 & 0.07 & 4.4 & 1.3 & 4.5 \\
\hline Junin, Ecuador & 2.5 & 2 & 3.9 & 0.4 & 0.4 & 0.13 & -- & -- & -- \\
\hline Panantza, Ecuador & -- & -- & -- & 0.8 & 0.2 & 0.04 & -- & -- & -- \\
\hline San Carlos, Ecuador & -- & -- & -- & 0.6 & 0.6 & 0.28 & 1.9 & 1.2 & 1.8 \\
\hline Namosi, Fiji & 6 & 4.8 & 23 & -- & -- & -- & -- & -- & -- \\
\hline Recsk, Hungary & -- & -- & -- & 2 & 1 & 1.6 & 3 & 1.4 & 3.4 \\
\hline Malanjkhand, India & -- & -- & -- & 2.6 & 0.7 & 0.72 & -- & -- & -- \\
\hline Batu Hijau, Indonesia & 6.5 & 3.5 & 18 & 1.2 & 0.6 & 0.57 & 3.5 & 2.5 & 6.9 \\
\hline Grasberg, Indonesia & 6 & 3 & 14 & 1 & 0.8 & 0.6 & 2 & 1.7 & 2.7 \\
\hline Kaputusan, Indonesia & 1.8 & 0.9 & 1.3 & 1 & 0.3 & 0.2 & -- & -- & -- \\
\hline Kale Kafi, Iran & -- & -- & -- & 1.4 & 0.7 & 0.77 & -- & -- & -- \\
\hline Meiduk, Iran & -- & -- & -- & 0.54 & 0.37 & 0.2 & -- & -- & -- \\
\hline
\end{tabular}


Table 2. Major and minor axes of extent of altered rock, orebodies, and sulfide-bearing rock in kilometers together with the total area of altered rock, ore, and sulfide-bearing area, in square kilometers for selected deposits, worldwide. The shortest dimension (minor axis) is measured by the distance between parallel lines that just touch the object. The major axis is measured to the ends of the object on a line perpendicular to the short axis. Areas are calculated assuming an elliptical object in plan view. The deposits are organized alphabetically by country. Dashed lines indicate no data available. (After Singer and others, 2008).-Continued

\begin{tabular}{|c|c|c|c|c|c|c|c|c|c|}
\hline Deposit & $\begin{array}{c}\text { Alteration } \\
\text { (major } \\
\text { axis) }\end{array}$ & $\begin{array}{l}\text { Alteration } \\
\text { (minor axis }\end{array}$ & $\begin{array}{l}\text { Altered } \\
\text { area }\end{array}$ & $\begin{array}{c}\text { Ore } \\
\text { (major } \\
\text { axis) }\end{array}$ & $\begin{array}{c}\text { Ore } \\
\text { (minor } \\
\text { axis) }\end{array}$ & $\begin{array}{l}\text { Ore } \\
\text { area }\end{array}$ & $\begin{array}{c}\text { Sulfides } \\
\text { (major axis) }\end{array}$ & $\begin{array}{c}\text { Sulfides } \\
\text { (minor axis) }\end{array}$ & $\begin{array}{c}\text { Sulfide } \\
\text { area }\end{array}$ \\
\hline Sar Cheshmeh, Iran & -- & -- & -- & 2.5 & 1 & 2 & -- & -- & -- \\
\hline Sungun, Iran & -- & -- & -- & 2.3 & 1.5 & 2.7 & -- & -- & -- \\
\hline Aktogai, Kazakhstan & 9.2 & 1 & 7.2 & -- & -- & -- & -- & -- & -- \\
\hline Boshchekul, Kazakhstan & 6.3 & 1.5 & 7.4 & 3 & 0.5 & 1.2 & -- & -- & -- \\
\hline Kounrad, Kazakhstan & -- & -- & -- & 1.2 & 0.8 & 0.75 & -- & -- & -- \\
\hline Taldy-Bulak, Kirgyzstan & -- & -- & -- & 1.2 & 0.8 & 0.75 & -- & -- & -- \\
\hline Kadiica, Macedonia & -- & -- & -- & 1 & 0.6 & 0.5 & -- & -- & -- \\
\hline Mamut, Malaysia & -- & -- & -- & 0.7 & 0.5 & 0.3 & 2.2 & 1.3 & 2.3 \\
\hline Nungkok, Malaysia & -- & -- & -- & 0.4 & 0.15 & 0.05 & -- & -- & -- \\
\hline Cananea, Mexico & -- & -- & -- & 3 & 1.5 & 3.5 & 7 & 4 & 22 \\
\hline El Arco, Mexico & 3.5 & 3.5 & 9.6 & 1.5 & 1.4 & 1.7 & -- & -- & -- \\
\hline La Caridad, Mexico & 4.5 & 4 & 14 & 2.4 & 1.7 & 3.2 & -- & -- & -- \\
\hline Milpillas, Mexico & 3.5 & 3.2 & 8.8 & 1.5 & 1.2 & 1.4 & -- & -- & -- \\
\hline Piedras Verdes, Mexico & 8 & 3 & 19 & 3 & 0.45 & 1.1 & -- & -- & -- \\
\hline Avdartolgoi, Mongolia & -- & -- & -- & 0.75 & 0.45 & 0.27 & -- & -- & -- \\
\hline Bayan Uul, Mongolia & 5 & 3 & 11.8 & -- & -- & -- & -- & -- & -- \\
\hline Erdenet, Mongolia & -- & -- & -- & 2.8 & 0.8 & 1.8 & 4.5 & 1.5 & 5.3 \\
\hline Khongor, Mongolia & -- & -- & -- & 1.7 & 0.33 & 0.44 & -- & -- & -- \\
\hline
\end{tabular}


Table 2. Major and minor axes of extent of altered rock, orebodies, and sulfide-bearing rock in kilometers together with the total area of altered rock, ore, and sulfide-bearing area, in square kilometers for selected deposits, worldwide. The shortest dimension (minor axis) is measured by the distance between parallel lines that just touch the object. The major axis is measured to the ends of the object on a line perpendicular to the short axis. Areas are calculated assuming an elliptical object in plan view. The deposits are organized alphabetically by country. Dashed lines indicate no data available. (After Singer and others, 2008).-Continued

\begin{tabular}{|c|c|c|c|c|c|c|c|c|c|}
\hline Deposit & $\begin{array}{l}\text { Alteration } \\
\text { (major } \\
\text { axis) }\end{array}$ & $\begin{array}{l}\text { Alteration } \\
\text { (minor axis }\end{array}$ & $\begin{array}{c}\text { Altered } \\
\text { area }\end{array}$ & $\begin{array}{c}\text { Ore } \\
\text { (major } \\
\text { axis) }\end{array}$ & $\begin{array}{c}\text { Ore } \\
\text { (minor } \\
\text { axis) }\end{array}$ & $\begin{array}{l}\text { Ore } \\
\text { area }\end{array}$ & $\begin{array}{c}\text { Sulfides } \\
\text { (major axis) }\end{array}$ & $\begin{array}{c}\text { Sulfides } \\
\text { (minor axis) }\end{array}$ & $\begin{array}{c}\text { Sulfide } \\
\text { area }\end{array}$ \\
\hline Oyu Tolgoi, Mongolia & -- & -- & -- & 6.5 & 0.6 & 3.1 & -- & -- & -- \\
\hline Oyuut Ulaar Ovoo, Mongolia & -- & -- & -- & 0.7 & 0.25 & 0.14 & -- & -- & -- \\
\hline Tsagaan-Suvarga, Mongolia & -- & -- & -- & 0.9 & 0.2 & 0.14 & 10 & 2 & 16 \\
\hline Haib, Namibia & 13 & 3 & 31 & 3.1 & 1.3 & 3.2 & 13 & 3 & 31 \\
\hline Saindak, Pakistan & 6.8 & 2 & 11 & 1.9 & 0.4 & 0.6 & 3.5 & 1.7 & 4.7 \\
\hline Cerro Colorado, Panama & 2.5 & 1.9 & 3.7 & 1.8 & 1.1 & 1.6 & -- & -- & -- \\
\hline $\begin{array}{l}\text { Frieda River, Papua-New } \\
\text { Guinea }\end{array}$ & 10 & 4 & 47 & -- & -- & -- & -- & -- & -- \\
\hline Ok Tedi, Papua-New Guinea & 3.6 & 1.8 & 5.1 & 1.8 & 0.77 & 1.1 & -- & -- & -- \\
\hline Panguna, Papua-New Guinea & 6 & 5.3 & 25 & 3 & 2 & 4.7 & -- & -- & -- \\
\hline Yandera, Papua-New Guinea & 8 & 3 & 19 & 1.6 & 0.25 & 0.3 & -- & -- & -- \\
\hline Cuajone, Peru & -- & -- & -- & 2 & 1 & 1.6 & 5 & 4 & 16 \\
\hline Magistral, Peru & -- & -- & -- & 1.2 & 0.13 & 0.12 & -- & -- & -- \\
\hline Michiquillay, Peru & 2.3 & 2 & 3.6 & 0.81 & 0.75 & 0.48 & 2 & 2 & 3.1 \\
\hline Minas Conga, Peru & -- & -- & -- & 1.3 & 0.6 & 0.59 & -- & -- & -- \\
\hline Pashpap, Peru & 1.5 & 1.5 & 1.8 & 1.2 & 0.3 & 0.3 & -- & -- & -- \\
\hline Quellaveco, Peru & -- & -- & -- & 2 & 1.1 & 1.7 & 3 & 1.5 & 3.5 \\
\hline Toquepala, Peru & -- & -- & -- & 2.1 & 1.8 & 3 & -- & -- & -- \\
\hline Toromocho, Peru & -- & -- & -- & 1.4 & 1 & 1.1 & -- & -- & -- \\
\hline
\end{tabular}


Table 2. Major and minor axes of extent of altered rock, orebodies, and sulfide-bearing rock in kilometers together with the total area of altered rock, ore, and sulfide-bearing area, in square kilometers for selected deposits, worldwide. The shortest dimension (minor axis) is measured by the distance between parallel lines that just touch the object. The major axis is measured to the ends of the object on a line perpendicular to the short axis. Areas are calculated assuming an elliptical object in plan view. The deposits are organized alphabetically by country. Dashed lines indicate no data available. (After Singer and others, 2008).-Continued

\begin{tabular}{|c|c|c|c|c|c|c|c|c|c|}
\hline Deposit & $\begin{array}{c}\text { Alteration } \\
\text { (major } \\
\text { axis) }\end{array}$ & $\begin{array}{l}\text { Alteration } \\
\text { (minor axis }\end{array}$ & $\begin{array}{l}\text { Altered } \\
\text { area }\end{array}$ & $\begin{array}{c}\text { Ore } \\
\text { (major } \\
\text { axis) }\end{array}$ & $\begin{array}{c}\text { Ore } \\
\text { (minor } \\
\text { axis) }\end{array}$ & $\begin{array}{l}\text { Ore } \\
\text { area }\end{array}$ & $\begin{array}{c}\text { Sulfides } \\
\text { (major axis) }\end{array}$ & $\begin{array}{c}\text { Sulfides } \\
\text { (minor axis) }\end{array}$ & $\begin{array}{c}\text { Sulfide } \\
\text { area }\end{array}$ \\
\hline Atlas, Philippines & -- & -- & -- & 3.1 & 0.75 & 1.8 & -- & -- & 60 \\
\hline Basay, Philippines & -- & -- & -- & 1.8 & 0.25 & 0.34 & -- & -- & 4.5 \\
\hline Boneng Lobo, Philippines & -- & -- & -- & 0.4 & 0.3 & 0.09 & -- & -- & 1.7 \\
\hline Boyongan, Philippines & -- & -- & -- & 1.2 & 0.5 & 0.47 & -- & -- & -- \\
\hline Dinkidi, Philippines & -- & -- & -- & 0.45 & 0.15 & 0.05 & -- & -- & -- \\
\hline Dizon, Philippines & -- & -- & -- & 0.55 & 0.4 & 0.17 & -- & -- & 8 \\
\hline Far Southeast, Philippines & 4.5 & 2 & 7.1 & -- & -- & -- & 1 & 0.7 & 0.5 \\
\hline Guinaoang-Tirad, Philippines & 2.3 & 2.1 & 3.8 & 1.1 & 0.5 & 0.43 & -- & -- & -- \\
\hline Hinobaan, Philippines & -- & -- & -- & 1.5 & 0.45 & 0.53 & -- & -- & -- \\
\hline Marcopper, Philippines & 3.4 & 2.5 & 6.7 & 1.7 & 0.64 & 0.85 & 2.7 & 2 & 4.2 \\
\hline Matanlang, Philippines & -- & -- & -- & 0.8 & 0.6 & 0.5 & -- & -- & -- \\
\hline $\begin{array}{l}\text { San Antonio-Philex, } \\
\text { Philippines }\end{array}$ & -- & -- & -- & 0.26 & 0.2 & 0.04 & -- & -- & 0.5 \\
\hline San Fabian, Philippines & -- & -- & -- & 1.3 & 0.3 & 0.3 & -- & -- & 1 \\
\hline Santo Tomas II, Philippines & -- & -- & -- & 0.57 & 0.46 & 0.21 & -- & -- & 1.3 \\
\hline Sipalay, Philipines & -- & -- & -- & 1.5 & 0.6 & 0.7 & -- & -- & -- \\
\hline Taysan, Philippines & 2.5 & 1.513 & -- & 0.5 & 0.4 & -- & -- & -- & -- \\
\hline Bolcana, Romania & 3 & 1.3 & 3.1 & 0.54 & 0.4 & 0.17 & -- & -- & -- \\
\hline
\end{tabular}


Table 2. Major and minor axes of extent of altered rock, orebodies, and sulfide-bearing rock in kilometers together with the total area of altered rock, ore, and sulfide-bearing area, in square kilometers for selected deposits, worldwide. The shortest dimension (minor axis) is measured by the distance between parallel lines that just touch the object. The major axis is measured to the ends of the object on a line perpendicular to the short axis. Areas are calculated assuming an elliptical object in plan view. The deposits are organized alphabetically by country. Dashed lines indicate no data available. (After Singer and others, 2008).-Continued

\begin{tabular}{|c|c|c|c|c|c|c|c|c|c|}
\hline Deposit & $\begin{array}{c}\text { Alteration } \\
\text { (major } \\
\text { axis) }\end{array}$ & $\begin{array}{c}\text { Alteration } \\
\text { (minor axis }\end{array}$ & $\begin{array}{c}\text { Altered } \\
\text { area }\end{array}$ & $\begin{array}{c}\text { Ore } \\
\text { (major } \\
\text { axis) }\end{array}$ & $\begin{array}{c}\text { Ore } \\
\text { (minor } \\
\text { axis) }\end{array}$ & $\begin{array}{l}\text { Ore } \\
\text { area }\end{array}$ & $\begin{array}{c}\text { Sulfides } \\
\text { (major axis) }\end{array}$ & $\begin{array}{c}\text { Sulfides } \\
\text { (minor axis) }\end{array}$ & $\begin{array}{c}\text { Sulfide } \\
\text { area }\end{array}$ \\
\hline Talagiu, Romania & 5.5 & 2.8 & 12 & 2.1 & 0.8 & 1.3 & -- & -- & -- \\
\hline Birgildinskoe, Russia & -- & -- & -- & 0.6 & 0.1 & 0.05 & 1.2 & 0.3 & 0.28 \\
\hline Nakhodka, Russia & -- & -- & -- & 2.8 & 1.1 & 2.4 & -- & -- & -- \\
\hline Peschanka, Russia & -- & -- & -- & 4.4 & 0.7 & 2.4 & -- & -- & -- \\
\hline Salavat, Russia & -- & -- & -- & 1.3 & 0.4 & 0.41 & -- & -- & -- \\
\hline Bor, Serbia & -- & -- & -- & 2 & 2.4 & 1.5 & -- & -- & -- \\
\hline Majdanpek, Serbia & -- & -- & -- & 4 & 0.3 & 0.94 & -- & -- & -- \\
\hline Rudnitsa, Serbia & 1.2 & 0.8 & 0.75 & 0.4 & 0.3 & 0.09 & -- & -- & -- \\
\hline Veliki Krivelj, Serbia & -- & -- & -- & 1.5 & 0.7 & 0.8 & -- & -- & -- \\
\hline Chimei, Taiwan & -- & -- & -- & 0.6 & 0.1 & 0.05 & 2.5 & 2 & 3.9 \\
\hline Derekoy, Turkey & 5 & 0.75 & 2.9 & 2.9 & 0.7 & 1.6 & -- & -- & -- \\
\hline Bagdad, USA & -- & -- & -- & 1.5 & 0.66 & 0.79 & -- & -- & -- \\
\hline Bingham, USA & -- & -- & -- & 2.4 & 1.3 & 2.4 & 6.5 & 4.8 & 25 \\
\hline Bisbee, USA & 2.7 & 2.7 & 5.9 & 0.61 & 0.61 & 0.29 & -- & -- & -- \\
\hline Castle Dome, USA & 2.7 & 1.5 & 3.3 & 0.91 & 0.46 & 0.33 & -- & -- & 2.6 \\
\hline Christmas, USA & 2 & 1.7 & 2.7 & 1.5 & 0.9 & 1.1 & -- & -- & -- \\
\hline Copper Basin, USA & -- & -- & -- & 1.4 & 1.4 & 1.5 & -- & -- & -- \\
\hline Copper Creek, USA & -- & -- & -- & 1.7 & 0.58 & 0.77 & -- & -- & 7.5 \\
\hline
\end{tabular}


Table 2. Major and minor axes of extent of altered rock, orebodies, and sulfide-bearing rock in kilometers together with the total area of altered rock, ore, and sulfide-bearing area, in square kilometers for selected deposits, worldwide. The shortest dimension (minor axis) is measured by the distance between parallel lines that just touch the object. The major axis is measured to the ends of the object on a line perpendicular to the short axis. Areas are calculated assuming an elliptical object in plan view. The deposits are organized alphabetically by country. Dashed lines indicate no data available. (After Singer and others, 2008).-Continued

\begin{tabular}{|c|c|c|c|c|c|c|c|c|c|}
\hline Deposit & $\begin{array}{c}\text { Alteration } \\
\text { (major } \\
\text { axis) }\end{array}$ & $\begin{array}{l}\text { Alteration } \\
\text { (minor axis }\end{array}$ & $\begin{array}{c}\text { Altered } \\
\text { area }\end{array}$ & $\begin{array}{c}\text { Ore } \\
\text { (major } \\
\text { axis) }\end{array}$ & $\begin{array}{c}\text { Ore } \\
\text { (minor } \\
\text { axis) }\end{array}$ & $\begin{array}{l}\text { Ore } \\
\text { area }\end{array}$ & $\begin{array}{c}\text { Sulfides } \\
\text { (major axis) }\end{array}$ & $\begin{array}{c}\text { Sulfides } \\
\text { (minor axis) }\end{array}$ & $\begin{array}{c}\text { Sulfide } \\
\text { area }\end{array}$ \\
\hline Copper Flat, USA & -- & -- & -- & 0.8 & 0.5 & 0.3 & -- & -- & -- \\
\hline Ely, USA & 12 & 1.2 & 11 & 7.3 & 0.91 & 5.2 & -- & -- & -- \\
\hline Ithaca Peak, USA & 4.1 & 3.7 & 12 & 1 & 0.67 & 0.55 & -- & -- & -- \\
\hline Mission-Pima, USA & 5.5 & 3.2 & 14 & 2.4 & 1.6 & 3 & 5.5 & 3.2 & 14 \\
\hline Morenci, USA & -- & -- & -- & 4 & 1.8 & 5.7 & -- & -- & 49 \\
\hline Pebble Copper, USA & -- & -- & -- & 1.6 & 0.8 & 1 & -- & -- & 89 \\
\hline Pyramid, USA & -- & -- & -- & 1 & 0.35 & 0.28 & 3.7 & 3 & 8.7 \\
\hline Ray, USA & 12 & 8.5 & 82 & 3 & 0.9 & 2.1 & -- & -- & 9.2 \\
\hline Red Mountain, USA & 3.5 & 3 & 8.2 & 1.7 & 0.3 & 0.4 & -- & -- & -- \\
\hline $\begin{array}{l}\text { San Manuel-Kalamazoo, } \\
\text { USA }\end{array}$ & -- & -- & -- & 4.6 & 0.95 & 3.4 & -- & -- & 6.6 \\
\hline Santa Rita, USA & -- & -- & -- & 2 & 1.3 & 2 & -- & -- & -- \\
\hline Sierrita-Esperanza, USA & -- & -- & -- & 2.2 & 0.89 & 1.6 & -- & -- & -- \\
\hline Silver Bell, USA & 10 & 3.5 & 28 & 2.5 & 1.3 & 2.6 & 4.8 & 2.4 & 9.1 \\
\hline Tyrone, USA & -- & -- & -- & 2.8 & 2 & 4.4 & -- & -- & -- \\
\hline
\end{tabular}


Table 3. Sulfide, supergene, and alteration mineralogy in a representative selection of porphyry-style copper deposits, worldwide. Minerals shown are as abstracted from the references cited and may not constitute a complete listing of minerals that occur in the deposit. Deposits are in alphabetical order by deposit name.

\begin{tabular}{|c|c|c|c|c|}
\hline Deposit & $\begin{array}{l}\text { Primary sulfide } \\
\text { mineralogy }\end{array}$ & Supergene mineralogy & $\begin{array}{c}\text { Primary alteration } \\
\text { mineralogy }\end{array}$ & References \\
\hline Ajo, Arizona, USA & $\begin{array}{l}\text { Chalcopyrite, bornite, pyrite, } \\
\text { molybdenite, sphalerite, tetrahedrite, } \\
\text { tennantite }\end{array}$ & $\begin{array}{l}\text { Chalcocite, cuprite, chrysocolla, } \\
\text { shattuckite, malachite, azurite, } \\
\text { native copper, opal, stibiconite, } \\
\text { melaconite, copper pitch, } \\
\text { brochantite, gypsum, hematite, } \\
\text { goethite, psilomelane, beidellite, } \\
\text { nontronite, alunite, jarosite }\end{array}$ & $\begin{array}{l}\text { Quartz, orthoclase, sericite, magnetite, } \\
\text { ilmenite, anhydrite, rutile, apatite, } \\
\text { albite, chlorite, epidote, clay, } \\
\text { specularite, dolomite, ankerite }\end{array}$ & $\begin{array}{l}\text { Gilluly (1946) } \\
\text { Dixon (1966) }\end{array}$ \\
\hline Almalyk (Kal'makyr), Uzbekistan & $\begin{array}{l}\text { Chalcopyrite, pyrite, molybdenite, } \\
\text { bornite, tetrahedrite, galena, sphalerite }\end{array}$ & $\begin{array}{l}\text { Chalcocite, cuprite, covellite, } \\
\text { malachite, azurite, chrysocolla, } \\
\text { ehlite, libethenite }\end{array}$ & $\begin{array}{l}\text { Quartz, K-feldspar, biotite, sericite, } \\
\text { magnetite, anhydrite, calcite }\end{array}$ & Golovanov and others (2005) \\
\hline Andacollo, Chile & $\begin{array}{l}\text { Chalcopyrite, pyrite, bornite, hematite, } \\
\text { molybdenite, pyrrhotite }\end{array}$ & $\begin{array}{l}\text { Chalcocite, azurite, malachite, } \\
\text { chrysocolla, cubanite }\end{array}$ & $\begin{array}{l}\text { Quartz, K-feldspar, biotite, anhydrite, } \\
\text { magnetite, sericite, rutile, chlorite, } \\
\text { epidote, calcite }\end{array}$ & $\begin{array}{l}\text { Reyes (1991) } \\
\text { Singer and others (2008) }\end{array}$ \\
\hline Bajo de la Alumbrera, Argentina & Chalcopyrite, pyrite & $\begin{array}{l}\text { Chalcocite, digenite, covellite with } \\
\text { goethite, jarosite }\end{array}$ & $\begin{array}{l}\text { Quartz, orthoclase, biotite, magnetite, } \\
\text { anhydrite, hematite, sericite, calcite }\end{array}$ & $\begin{array}{l}\text { Guilbert (1995) } \\
\text { Singer and others (2008) }\end{array}$ \\
\hline Batu Hijau, Sumbawa, Indonesia & $\begin{array}{l}\text { Chalcopyrite, bornite, pyrite, } \\
\text { chalcocite, digenite, native gold, } \\
\text { sphalerite, galena, tennantite }\end{array}$ & Chalcocite, covellite, cuprite & $\begin{array}{l}\text { Quartz, biotite, albite-oligoclase, } \\
\text { magnetite, sericite, actinolite, epidote, } \\
\text { chlorite, calcite, specularite, kaolinite, } \\
\text { alunite, pyrophyllite, tourmaline }\end{array}$ & $\begin{array}{l}\text { Meldrum and others (1994) } \\
\text { Garwin (2002) }\end{array}$ \\
\hline Bingham, Utah, USA & $\begin{array}{l}\text { Chalcopyrite, bornite, pyrite, } \\
\text { molybdenite, chalcocite, digenite, } \\
\text { covellite, enargite, famatinite, galena, } \\
\text { sphalerite, tetrahedrite }\end{array}$ & $\begin{array}{l}\text { Chalcocite, covellite, anglesite, } \\
\text { azurite, cerussite, chalcanthite, } \\
\text { cuprite, goslarite, malachite, } \\
\text { melanterite, native copper, native } \\
\text { silver, native gold, tenorite }\end{array}$ & $\begin{array}{l}\text { Quartz, K-feldspar, biotite, apatite, } \\
\text { actinolite, sericite, kaolinite, } \\
\text { montmorillonite, chlorite, epidote, } \\
\text { calcite }\end{array}$ & $\begin{array}{l}\text { Peters and others (1966) } \\
\text { Babcock and others (1995) }\end{array}$ \\
\hline Cadia, New South Wales, Australia & $\begin{array}{l}\text { Chalcopyrite, bornite, molybdenite, } \\
\text { pyrite, native gold, covellite, sphalerite, } \\
\text { galena, tetrahedrite }\end{array}$ & Chalcocite, digenite, covellite & $\begin{array}{l}\text { Quartz, orthoclase, biotite, magnetite, } \\
\text { sericite, chlorite, albite, actinolite, } \\
\text { epidote, calcite, tourmaline, hematite, } \\
\text { fluorite }\end{array}$ & $\begin{array}{l}\text { Holliday and others (2002) } \\
\text { Wilson and others (2007) } \\
\text { Singer and others (2008) }\end{array}$ \\
\hline Campana Mahuida, Argentina & $\begin{array}{l}\text { Chalcopyrite, bornite, molybdenite, } \\
\text { pyrite, pyrrhotite, native gold }\end{array}$ & $\begin{array}{l}\text { Chalcocite, covellite, chrysocolla, } \\
\text { tenorite }\end{array}$ & $\begin{array}{l}\text { Biotite, quartz, orthoclase, magnetite, } \\
\text { sericite, albite, tourmaline, chlorite, } \\
\text { epidote, calcite, illite, smectite }\end{array}$ & $\begin{array}{l}\text { Franchini, and others (2007) } \\
\text { Singer and others (2008) }\end{array}$ \\
\hline Cananea, Sonora, Mexico & $\begin{array}{l}\text { Chalcopyrite, pyrite, bornite, } \\
\text { molybdenite, sphalerite, galena, } \\
\text { enargite, luzonite }\end{array}$ & Chalcocite, digenite, covellite & $\begin{array}{l}\text { Quartz, K-feldspar, biotite, sericite, } \\
\text { tourmaline, magnetite, actinolite, } \\
\text { chlorite, carbonate, epidote, alunite }\end{array}$ & $\begin{array}{l}\text { Velasco (1966) } \\
\text { Singer and others (2008) }\end{array}$ \\
\hline
\end{tabular}


Table 3. Sulfide, supergene, and alteration mineralogy in a representative selection of porphyry-style copper deposits, worldwide. Minerals shown are as abstracted from the references cited and may not constitute a complete listing of minerals that occur in the deposit. Deposits are in alphabetical order by deposit name.-Continued

\begin{tabular}{|c|c|c|c|c|}
\hline Deposit & $\begin{array}{l}\text { Primary sulfide } \\
\text { mineralogy }\end{array}$ & Supergene mineralogy & $\begin{array}{c}\text { Primary alteration } \\
\text { mineralogy }\end{array}$ & References \\
\hline Castle Dome, Arizona, USA & $\begin{array}{l}\text { Chalcopyrite, pyrite, molybdenite, } \\
\text { sphalerite, galena }\end{array}$ & $\begin{array}{l}\text { Chalcocite, covellilte, azurite, } \\
\text { malachite, native copper, cuprite, } \\
\text { chalcanthite, native silver, } \\
\text { turquoise }\end{array}$ & $\begin{array}{l}\text { Quartz, K-feldspar, biotite, sericite, } \\
\text { anhydrite, chlorite, epidote, } \\
\text { clinozoisite, calcite, tourmaline, } \\
\text { fluorite, barite }\end{array}$ & $\begin{array}{l}\text { Peterson and others (1946) } \\
\text { Singer and others (2008) }\end{array}$ \\
\hline Chuquicamata, Chile & $\begin{array}{l}\text { Chalcopyrite, bornite, pyrite, } \\
\text { molybdenite, digenite, enargite, } \\
\text { covellite, tennantite, sphalerite }\end{array}$ & $\begin{array}{l}\text { Chalcocite, covellite, djurleite, } \\
\text { digenite, antlerite, brochantite, } \\
\text { atacamite, chrysocolla, copper } \\
\text { pitch, chenevixite, chalcanthite, } \\
\text { krohnkite, natrochalcite }\end{array}$ & $\begin{array}{l}\text { Quartz, K-feldspar, biotite, anhydrite, } \\
\text { sericite, magnetite, albite, chlorite, } \\
\text { epidote, specularite }\end{array}$ & $\begin{array}{l}\text { Ossandón C. and others (2001) } \\
\text { Sillitoe (2005) }\end{array}$ \\
\hline Copper Cities, Arizona, USA & $\begin{array}{l}\text { Chalcopyrite, pyrite, molybdenite, } \\
\text { sphalerite, galena }\end{array}$ & $\begin{array}{l}\text { Chalcocite, covellite, malachite, } \\
\text { azurite, turquoise, metatorbernite } \\
\text { with montmorillonite, sericite }\end{array}$ & $\begin{array}{l}\text { Quartz, K-feldspar, biotite, epidote, } \\
\text { calcite, clinozoisite }\end{array}$ & Simmons and Fowells (1966) \\
\hline Dexing, China & $\begin{array}{l}\text { Chalcopyrite, bornite, pyrite, } \\
\text { molybdenite, sphalerite, tennantite }\end{array}$ & $\begin{array}{l}\text { Chalcocite, cubanite, cuprite, } \\
\text { tenorite, djurleite, malachite }\end{array}$ & $\begin{array}{l}\text { Quartz, K-feldspar, biotite, sericite, } \\
\text { anhydrite, magnetite, apatite, chlorite, } \\
\text { albite, calcite, hematite, barite, } \\
\text { tourmaline }\end{array}$ & $\begin{array}{l}\text { Li and Sasaki (2007) } \\
\text { Singer and others (2008) }\end{array}$ \\
\hline El Abra, Chile & $\begin{array}{l}\text { Chalcopyrite, bornite, pyrite, enargite, } \\
\text { chalcocite }\end{array}$ & $\begin{array}{l}\text { Chrysocolla, atacamite, malachite, } \\
\text { antlerite, brochantite, copper pitch, } \\
\text { cuprite, tenorite, native copper, } \\
\text { chalcocite with kaolinite, sericite, } \\
\text { montmorillonite, nontronite }\end{array}$ & $\begin{array}{l}\text { Quartz, K-feldspar, biotite, magnetite, } \\
\text { ilmenite, perthite, rutile, apatite, } \\
\text { anhydrite, sericite, pyrophyllite, } \\
\text { kaolinite, chlorite, epidote, albite, } \\
\text { specularite, zeolites, carbonates, } \\
\text { tourmaline }\end{array}$ & Ambrus (1977) \\
\hline El Salvador, Chile & $\begin{array}{l}\text { Chalcopyrite, bornite, pyrite, } \\
\text { molybdenite, enargite, tennantite, } \\
\text { galena, sphalerite }\end{array}$ & $\begin{array}{l}\text { Chalcocite, digenite, covellite, } \\
\text { brochantite, chrysocolla }\end{array}$ & $\begin{array}{l}\text { Quartz, K-feldspar, biotite, sericite, } \\
\text { Na-plagioclase, anhydrite, magnetite, } \\
\text { actinolite, chlorite, rutile, tourmaline, } \\
\text { kaolinite, andalusite, corundum, } \\
\text { diaspore, pyrophyllite, svenbergite, } \\
\text { woodhouseite, zunyite, calcite, epidote, } \\
\text { hematite }\end{array}$ & $\begin{array}{l}\text { Gustafson and Hunt (1975) } \\
\text { Sillitoe (2005) } \\
\text { Singer and others (2008) }\end{array}$ \\
\hline El Teniente, Chile & $\begin{array}{l}\text { Chalcopyrite, bornite, pyrite, } \\
\text { molybdenite, tennantite-tetrahedrite, } \\
\text { enargite, galena, sphalerite }\end{array}$ & $\begin{array}{l}\text { Chrysocolla, malachite, } \\
\text { brochantite, antlerite, cuprite, } \\
\text { native copper, azurite, tenorite, } \\
\text { olivenite, chalcophyllite }\end{array}$ & $\begin{array}{l}\text { Quartz, K-feldspar, biotite, anhydrite, } \\
\text { magnetite, albite, tourmaline, chlorite, } \\
\text { carbonate, epidote, specularite, rutile, } \\
\text { apatite }\end{array}$ & $\begin{array}{l}\text { Camus (1975) } \\
\text { Sillitoe 2005) } \\
\text { Klemm and others (2007) }\end{array}$ \\
\hline Ely, Nevada, USA & $\begin{array}{l}\text { Chalcopyrite, bornite, pyrite, } \\
\text { molybdenite }\end{array}$ & Chalcocite, covellite & $\begin{array}{l}\text { Quartz, K-feldspar, biotite, sericite, } \\
\text { magnetite, specularite }\end{array}$ & Bauer and others (1966) \\
\hline
\end{tabular}


Table 3. Sulfide, supergene, and alteration mineralogy in a representative selection of porphyry-style copper deposits, worldwide. Minerals shown are as abstracted

from the references cited and may not constitute a complete listing of minerals that occur in the deposit. Deposits are in alphabetical order by deposit name.-Continued

\begin{tabular}{|c|c|c|c|c|}
\hline Deposit & $\begin{array}{l}\text { Primary sulfide } \\
\text { mineralogy }\end{array}$ & Supergene mineralogy & $\begin{array}{c}\text { Primary alteration } \\
\text { mineralogy }\end{array}$ & References \\
\hline Escondida, Chile & $\begin{array}{l}\text { Chalcopyrite, pyrite, molybdenite, } \\
\text { enargite, covellite, sphalerite, galena, } \\
\text { tennantite }\end{array}$ & $\begin{array}{l}\text { Brochantite, antlerite, } \\
\text { chrysocolla, neotocite, tenorite, } \\
\text { chalcanthite, cuprite, native } \\
\text { copper, turquoise, libethenite, } \\
\text { malachite }\end{array}$ & $\begin{array}{l}\text { Quartz, K-feldspar, biotite, anhydrite, } \\
\text { sericite, magnetite, chlorite, epidote, } \\
\text { calcite, alunite, pyrophyllite, diaspore, } \\
\text { svenbergite }\end{array}$ & $\begin{array}{l}\text { Alpers and Brimhall (1989) } \\
\text { Padilla-Garza and others (2004) } \\
\text { Sillitoe (2005) }\end{array}$ \\
\hline Esperanza, Chile & $\begin{array}{l}\text { Chalcopyrite, bornite, pyrite, } \\
\text { molybdenite, chalcocite, native gold }\end{array}$ & $\begin{array}{l}\text { Chalcocite, atacamite, brochantite, } \\
\text { chrysocolla }\end{array}$ & $\begin{array}{l}\text { Quartz, K-feldspar, biotite, magnetite, } \\
\text { anhydrite, chlorite, apatite, rutile, } \\
\text { tourmaline, sericite, illite, epidote, } \\
\text { calcite }\end{array}$ & $\begin{array}{l}\text { Perrelló and others (2004) } \\
\text { Singer and others (2008) }\end{array}$ \\
\hline Far South East, Philippines & $\begin{array}{l}\text { Chalcopyrite, pyrite, bornite, } \\
\text { molybdenite, sphalerite, tetrahedrite, } \\
\text { tennantite, enargite, luzonite, marcasite }\end{array}$ & & $\begin{array}{l}\text { Quartz, biotite, magnetite, anhydrite, } \\
\text { chlorite, tourmaline, alunite, } \\
\text { pyrophyllite, diaspore, barite }\end{array}$ & Singer and others (2008) \\
\hline $\begin{array}{l}\text { Goonumbla, New South Wales, } \\
\text { Australia }\end{array}$ & $\begin{array}{l}\text { Chalcopyrite, bornite, pyrite, native } \\
\text { gold, chalcocite, tetrahedrite }\end{array}$ & $\begin{array}{l}\text { Malachite, azurite, chrysocolla, } \\
\text { native copper, chalcocite }\end{array}$ & $\begin{array}{l}\text { Quartz, K-feldspar, biotite, sericite, } \\
\text { magnetite, anhydrite, carbonates, } \\
\text { amphibole, chlorite, epidote }\end{array}$ & Jones (1985) \\
\hline Grasberg, Indonesia & $\begin{array}{l}\text { Chalcopyrite, bornite, pyrite, digenite, } \\
\text { covellite }\end{array}$ & $\begin{array}{l}\text { Chalcopyrite with sericite, } \\
\text { kaolinite, montmorillonite }\end{array}$ & $\begin{array}{l}\text { Quartz, biotite, K-feldspar, magnetite, } \\
\text { anhydrite, sericite, albite, actinolite, } \\
\text { kaolinite, chlorite, epidote, hematite }\end{array}$ & MacDonald and Arnold (1994) \\
\hline Kingking, Philippines & $\begin{array}{l}\text { Chalcopyrite, bornite, native gold, } \\
\text { calaverite }\end{array}$ & Chalcocite & $\begin{array}{l}\text { Quartz, K-feldspar, biotite, sericite, } \\
\text { anhydrite, magnetite, chlorite, epidote, } \\
\text { kaolinite }\end{array}$ & $\begin{array}{l}\text { Suerte and others (2007) } \\
\text { Singer and others (2008) }\end{array}$ \\
\hline Los Pelambres, Chile & $\begin{array}{l}\text { Chalcopyrite, bornite, pyrite, } \\
\text { molybdenite }\end{array}$ & $\begin{array}{l}\text { Malachite, azurite, chrysocolla, } \\
\text { chalcanthite, brochantite, gypsum, } \\
\text { chalcocite, djurleite }\end{array}$ & $\begin{array}{l}\text { Quartz, K-feldspar, biotite, anhydrite, } \\
\text { sericite, calcite, apatite, chlorite, } \\
\text { albite-oligoclase, tourmaline, rutile, } \\
\text { magnetite, tourmaline, kaolinite, } \\
\text { chlorite, epidote, specularite }\end{array}$ & Sillitoe (1973) \\
\hline Michiquillay, Peru & $\begin{array}{l}\text { Chalcopyrite, pyrite, molybdenite, } \\
\text { sphalerite, galena, enargite, marcasite, } \\
\text { arsenopyrite }\end{array}$ & Chalcocite, covellite & $\begin{array}{l}\text { Quartz, K-feldspar, biotite, sericite, } \\
\text { magnetite, anhydrite, chlorite, } \\
\text { tourmaline, carbonate, alunite, } \\
\text { kaolinite, barite, pyrophyllite }\end{array}$ & $\begin{array}{l}\text { Hollister and Sirvas (1974) } \\
\text { Singer and others (2008) }\end{array}$ \\
\hline Miduk, Iran & $\begin{array}{l}\text { Chalcopyrite, pyrite, bornite, } \\
\text { molybdenite, sphalerite, galena, } \\
\text { tetrahedrite }\end{array}$ & $\begin{array}{l}\text { Chalcocite, covellite, azurite, } \\
\text { malachite, chalcanthite, } \\
\text { chrysocolla, turquoise }\end{array}$ & $\begin{array}{l}\text { Quartz, K-feldspar, biotite, sericite, } \\
\text { magnetite, anhydrite, clay, rutile, } \\
\text { magnetite, hematite, chlorite, epidote, } \\
\text { calcite }\end{array}$ & $\begin{array}{l}\text { Taghipour and others (2008) } \\
\text { Singer and others (2008) }\end{array}$ \\
\hline
\end{tabular}


Table 3. Sulfide, supergene, and alteration mineralogy in a representative selection of porphyry-style copper deposits, worldwide. Minerals shown are as abstracted from the references cited and may not constitute a complete listing of minerals that occur in the deposit. Deposits are in alphabetical order by deposit name.-Continued

\begin{tabular}{|c|c|c|c|c|}
\hline Deposit & $\begin{array}{l}\text { Primary sulfide } \\
\text { mineralogy }\end{array}$ & Supergene mineralogy & $\begin{array}{c}\text { Primary alteration } \\
\text { mineralogy }\end{array}$ & References \\
\hline Morenci, Arizona, USA & $\begin{array}{l}\text { Chalcopyrite, pyrite, molybdenite, } \\
\text { sphalerite, galena, native gold }\end{array}$ & $\begin{array}{l}\text { Chalcocite, covellite, native } \\
\text { copper, cuprite, turquoise, } \\
\text { chrysocolla, malachite, tenorite, } \\
\text { brochantite, azurite chalcanthite, } \\
\text { copiopite }\end{array}$ & $\begin{array}{l}\text { Quartz, K-feldspar, biotite, sericite, } \\
\text { chlorite }\end{array}$ & Moolick and Durek (1966) \\
\hline Ok Tedi, Papua-New Guinea & $\begin{array}{l}\text { Chalcopyrite, bornite, pyrite, marcasite, } \\
\text { molybdenite }\end{array}$ & $\begin{array}{l}\text { Chalcocite, digenite, djurleite, } \\
\text { covellite, copper pitch, turquoise, } \\
\text { chrysocolla }\end{array}$ & $\begin{array}{l}\text { Quartz, biotite, K-feldspar, rutile, } \\
\text { magnetite, hematite }\end{array}$ & $\begin{array}{l}\text { Bamford (1972) } \\
\text { Howell and others (1978) }\end{array}$ \\
\hline Oyu Tolgoi, Mongolia & $\begin{array}{l}\text { Chalcopyrite, bornite, pyrite, } \\
\text { chalcocite, enargite, tennantite }\end{array}$ & $\begin{array}{l}\text { Chalcocite, covellite, malachite, } \\
\text { chrysocolla, arsenosulvanite, } \\
\text { native copper, tenorite }\end{array}$ & $\begin{array}{l}\text { Quartz, biotite, albite, magnetite, } \\
\text { muscovite, K-feldspar, actinolite, } \\
\text { illite, chlorite, siderite, fluorite, } \\
\text { calcite, dolomite, alunite, pyrophyllite, } \\
\text { diaspore, zunyite, topaz, corundum, } \\
\text { andalusite, kaolinite, dickite }\end{array}$ & $\begin{array}{l}\text { Khashgerel and others (2006) } \\
\text { Singer and others (2008) }\end{array}$ \\
\hline $\begin{array}{l}\text { Panguna, Bougainville, Papua New } \\
\text { Guinea }\end{array}$ & $\begin{array}{l}\text { Chalcopyrite, pyrite, bornite, } \\
\text { molybdenite, digenite, galena, } \\
\text { sphalerite, bravoite, tennantite, } \\
\text { stannite, pyrrhotite }\end{array}$ & Chalcocite, covellite & $\begin{array}{l}\text { Quartz, biotite, K-feldspar, magnetite, } \\
\text { anhydrite, hematite, rutile, albite, } \\
\text { sericite, chlorite, epidote, calcite, } \\
\text { actinolite, kaolinite }\end{array}$ & $\begin{array}{l}\text { Eastoe (1978) } \\
\text { Ford (1978) } \\
\text { Singer and others (2008) }\end{array}$ \\
\hline Pebble, Alaska, USA & $\begin{array}{l}\text { Chalcopyrite, pyrite, bornite, } \\
\text { molybdenite, native gold, galena, } \\
\text { sphalerite }\end{array}$ & Covellite, digenite, chalcocite & $\begin{array}{l}\text { Quartz, orthoclase, biotite, sericite, } \\
\text { anhydrite, apatite, rutile, albite, } \\
\text { carbonate }\end{array}$ & Bouley and others (1995) \\
\hline Portrerillos, Chile & $\begin{array}{l}\text { Chalcopyrite, pyrite, bornite, } \\
\text { arsenopyrite, sphalerite, stibnite, } \\
\text { galena, tetrahedrite }\end{array}$ & $\begin{array}{l}\text { Chalcocite, covellite, brochantite, } \\
\text { copper pitch, chrysocolla, azurite, } \\
\text { cuprite, native copper, malachite, } \\
\text { libethenite, native silver }\end{array}$ & $\begin{array}{l}\text { Quartz, K-feldspar, biotite, magnetite, } \\
\text { anhydrite, carbonate, alunite, } \\
\text { pyrophyllite, diaspore, kaolinite, } \\
\text { woodhouseite, zunyite }\end{array}$ & $\begin{array}{l}\text { Sillitoe (2005) } \\
\text { Singer and others (2008) }\end{array}$ \\
\hline Quebrada Blanca, Chile & $\begin{array}{l}\text { Chalcopyrite, bornite, pyrite, } \\
\text { molybdenite }\end{array}$ & $\begin{array}{l}\text { Brochantite, chrysocolla, cuprite, } \\
\text { native copper, chalcocite }\end{array}$ & $\begin{array}{l}\text { Quartz, K-feldspar, biotite, chlorite, } \\
\text { epidote, tourmaline }\end{array}$ & $\begin{array}{l}\text { Sillitoe (2005) } \\
\text { Singer and others (2008) }\end{array}$ \\
\hline Quellaveco, Peru & $\begin{array}{l}\text { Chalcopyrite, pyrite, molybdenite, } \\
\text { enargite, sphalerite, galena }\end{array}$ & $\begin{array}{l}\text { Chalcocite, covellite, brochantite, } \\
\text { chrysocolla, malachite, copper } \\
\text { pitch, cubanite, cuprite, native } \\
\text { copper, turquoise }\end{array}$ & Quartz, sericite, epidote & $\begin{array}{l}\text { Sillitoe (2005) } \\
\text { Singer and others (2008) }\end{array}$ \\
\hline Ray, Arizona, USA & $\begin{array}{l}\text { Chalcopyrite, pyrite, bornite, } \\
\text { molybdenite, galena, sphalerite }\end{array}$ & $\begin{array}{l}\text { Chalcocite, covellite, native } \\
\text { copper, cuprite, chalcotrichite, } \\
\text { native silver, chrysocolla }\end{array}$ & $\begin{array}{l}\text { Quartz, biotite, orthoclase, sericite, } \\
\text { kaolinite, montmorillonite, chlorite, } \\
\text { epidote, albite, carbonate }\end{array}$ & Metz and Rose (1966) \\
\hline
\end{tabular}

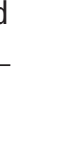


Table 3. Sulfide, supergene, and alteration mineralogy in a representative selection of porphyry-style copper deposits, worldwide. Minerals shown are as abstracted

from the references cited and may not constitute a complete listing of minerals that occur in the deposit. Deposits are in alphabetical order by deposit name.-Continued

\begin{tabular}{|c|c|c|c|c|}
\hline Deposit & $\begin{array}{l}\text { Primary sulfide } \\
\text { mineralogy }\end{array}$ & Supergene mineralogy & $\begin{array}{c}\text { Primary alteration } \\
\text { mineralogy }\end{array}$ & References \\
\hline Río Blanco-Los Bronces, Chile & $\begin{array}{l}\text { Chalcopyrite, bornite, molybdenite, } \\
\text { pyrite, luzonite, enargite, tennantite, } \\
\text { valleriite, sphalerite, galena, } \\
\text { arsenopyrite }\end{array}$ & $\begin{array}{l}\text { Antlerite, brochantite, } \\
\text { chalcanthite, copper pitch, } \\
\text { neotocite, chrysocolla, chalcocite, } \\
\text { covellite, native copper, cuprite }\end{array}$ & $\begin{array}{l}\text { Quartz, biotite, K-feldspar, anhydrite, } \\
\text { actinolite, magnetite, sericite, } \\
\text { plagioclase, tourmaline, chlorite, } \\
\text { hematite, carbonates, epidote, alunite, } \\
\text { pyrophyllite, barite }\end{array}$ & $\begin{array}{l}\text { Warnaars and others (1985) } \\
\text { Vargas R. and others (1999) } \\
\text { Deckart and others (2005) } \\
\text { Sillitoe (2005) }\end{array}$ \\
\hline Rosia Poieni, Romania & Chalcopyrite, pyrite, enargite, luzonite & Scorodite, goethite, alunite & $\begin{array}{l}\text { Quartz, biotite, K-feldspar, perthite, } \\
\text { rutile, anhydrite, magnetite, albite, } \\
\text { illite, smectite, kaolinite, chlorite, } \\
\text { epidote, carbonate, alunite, dickite, } \\
\text { pyrophyllite, diaspore, zunyite, } \\
\text { minamiite }\end{array}$ & Milu and others (2004) \\
\hline $\begin{array}{l}\text { San Manuel-Kalamazoo, Arizona, } \\
\text { USA }\end{array}$ & $\begin{array}{l}\text { Chalcopyrite, pyrite, bornite, } \\
\text { molybdenite }\end{array}$ & $\begin{array}{l}\text { Chalcocite, covellite, bornite, } \\
\text { chrysocolla, cuprite, malachite, } \\
\text { native copper, atacamite, } \\
\text { plancheite }\end{array}$ & $\begin{array}{l}\text { Quartz, K-feldspar, biotite, magnetite, } \\
\text { sericite, anhydrite, chlorite, epidote, } \\
\text { calcite }\end{array}$ & $\begin{array}{l}\text { Thomas (1966) } \\
\text { Sandbak and Alexander (1995) }\end{array}$ \\
\hline Santa Rita, New Mexico, USA & $\begin{array}{l}\text { Chalcopyrite, bornite, pyrite, } \\
\text { molybdenite, marcasite, pyrrhotite, } \\
\text { sphalerite, galena }\end{array}$ & $\begin{array}{l}\text { Chalcocite, covellite, native } \\
\text { copper, chrysocolla, cuprite, } \\
\text { malachite, azurite, turquoise, } \\
\text { melaconite, libethenite }\end{array}$ & $\begin{array}{l}\text { Quartz, orthoclase, biotite, epidote, } \\
\text { sericite, chlorite }\end{array}$ & Rose and Baltosser (1966) \\
\hline Sar Cheshmeh, Iran & $\begin{array}{l}\text { Chalcopyrite, bornite, pyrite, } \\
\text { molybdenite }\end{array}$ & Chalcocite, digenite, covellite & $\begin{array}{l}\text { Quartz, K-feldspar, biotite, anhydrite, } \\
\text { albite, sericite, kaolinite, illite, chlorite, } \\
\text { epidote }\end{array}$ & $\begin{array}{l}\text { Waterman and Hamilton (1975) } \\
\text { Hezarkhani (2006) }\end{array}$ \\
\hline Silver Bell, Arizona, USA & Chalcopyrite, pyrite, molybdenite & $\begin{array}{l}\text { Chalcocite, azurite, malachite, } \\
\text { brochantite, chalcanthite, cuprite, } \\
\text { chrysocolla, native copper, tenorite }\end{array}$ & $\begin{array}{l}\text { Quartz, biotite, sericite, actinolite, } \\
\text { chlorite }\end{array}$ & $\begin{array}{l}\text { Richard and Courtright (1966) } \\
\text { Singer and others (2008) }\end{array}$ \\
\hline Tongshankou, China & $\begin{array}{l}\text { Chalcopyrite, pyrite, bornite, } \\
\text { sphalerite, tetrahedrite, molybdenite }\end{array}$ & & $\begin{array}{l}\text { Quartz, orthoclase, biotite, quartz, } \\
\text { magnetite, hematite, sericite, calcite }\end{array}$ & $\mathrm{Li}$ and others (2008) \\
\hline Toquepala, Peru & $\begin{array}{l}\text { Chalcopyrite, pyrite, molybdenite, } \\
\text { bornite, tennantite, cobaltite, } \\
\text { mackinawite, enargite, sphalerite, } \\
\text { galena }\end{array}$ & Chalcocite, digenite, native copper & $\begin{array}{l}\text { Tourmaline, quartz, K-feldspar, albite, } \\
\text { biotite, sericite, anhydrite, magnetite, } \\
\text { apatite, rutile, chlorite, actinolite, } \\
\text { andalusite, siderite, pyrophyllite }\end{array}$ & $\begin{array}{l}\text { Zweng and Clark (1995) } \\
\text { Singer and others (2008) }\end{array}$ \\
\hline $\begin{array}{l}\text { Valley Copper, British Columbia, } \\
\text { Canada }\end{array}$ & $\begin{array}{l}\text { Chalcopyrite, bornite, molybdenite, } \\
\text { pyrite, enargite, tetrahedrite, sphalerite, } \\
\text { galena, scheelite }\end{array}$ & $\begin{array}{l}\text { Chalcocite, digenite, covellite, } \\
\text { azurite, malachite, native copper, } \\
\text { cuprite, powellite, tenorite }\end{array}$ & $\begin{array}{l}\text { Quartz, K-feldspar, sericite, biotite, } \\
\text { anhydrite, magnetite, calcite, hematite, } \\
\text { kaolinite, chlorite, epidote, fluorite }\end{array}$ & $\begin{array}{l}\text { Osatenko and Jones (1976) } \\
\text { Singer and others (2008) }\end{array}$ \\
\hline
\end{tabular}


Table 3. Sulfide, supergene, and alteration mineralogy in a representative selection of porphyry-style copper deposits, worldwide. Minerals shown are as abstracted from the references cited and may not constitute a complete listing of minerals that occur in the deposit. Deposits are in alphabetical order by deposit name.-Continued

\begin{tabular}{|c|c|c|c|c|}
\hline Deposit & $\begin{array}{l}\text { Primary sulfide } \\
\text { mineralogy }\end{array}$ & Supergene mineralogy & $\begin{array}{c}\text { Primary alteration } \\
\text { mineralogy }\end{array}$ & References \\
\hline Wasoi, Namosi District, Fiji & $\begin{array}{l}\text { Chalcopyrite, bornite, pyrite, } \\
\text { molybdenite, native gold, galena, } \\
\text { sphalerite }\end{array}$ & $\begin{array}{l}\text { Chalcocite, covellite, chrysocolla, } \\
\text { native copper, cuprite, malachite, } \\
\text { neotocite }\end{array}$ & $\begin{array}{l}\text { Quartz, biotite, magnetite, sericite, } \\
\text { chlorite, epidote, carbonate }\end{array}$ & $\begin{array}{l}\text { Imai and others (2007) } \\
\text { Singer and others (2008) }\end{array}$ \\
\hline
\end{tabular}


Table 4. Alteration-mineral assemblages in the Copper Mountain (British Columbia, Canada) and El Teniente (Chile) porphyry copper deposits.

Pervasive style

\section{Minerals}

\section{Copper Mountain, British Columbia, Canada}

Sodic variety

Potassic variety

Kaolinitic variety

Propylitic variety

\section{Vein style}

Magnetite stringers

Biotite stringers

K-feldspar veins

Pegmatitic "barren"

veins

Pegmatitic bornitechalcopyrite veins

Pegmatitic

chalcopyrite-pyrite

veins

Bornite-chalcopyrite

veins

Chalcopyrite stringers

Magnetite-sulfide veins

Hematite-sulfide veins

K-feldspar-epidote

veins

Chlorite veins

Chlorite-sulfide-calcite

veins

Epidote veins

Albite-K-feldspar-

scapolite veins

Sericite veins

Quartz veins

Zeolite veins

Calcite veins
Oligoclase/albite after plagioclase; minor amounts of epidote, diopside, and calcite after ferromagnesian silicates; magnetite destroyed; pyrite only sulfide, generally rare; fine grained where alteration very intense; may be overprinted by potassic variety alteration assemblage

Summary: Albite + epidote + (chlorite) $+($ calcite $) \pm$ diopside

K-feldspar after plagioclase; biotite, epidote, and calcite after ferromagnesian silicates; magnetite present; minor sulfides, predominantly pyrite

Summary: K-feldspar + biotite + magnetite + epidote \pm chlorite

Texturally destructive style; kaolinite, sericite, calcite, pyrite; minor quartz, chlorite, and epidote

Summary: Kaolinite + sericite + calcite + pyrite $+($ quartz $)+($ chlorite $)+($ epidote $)$

Chlorite, actinolite, epidote, and calcite replacement of ferromagnesian minerals; oligoclase/albite, epidote, and calcite replacement of plagioclase and K-feldspar; pyrite, specular hematite, minot magnetite

Summary: Chlorite + actinolite + epidote + calcite + albite + (pyrite) + (hematite)

$\pm(\mathrm{K}$-feldspar $)$

Biotite replaced by chlorite

$\mathrm{K}$-feldspar + albite $+($ calcite $)+($ epidote $)+$ minor magnetite + minor apatite $+($ titanite $)$

$\mathrm{K}$-feldspar \pm (biotite) replaced by (chlorite)

K-feldspar \pm (biotite) replaced by (chlorite)

$\mathrm{K}$-feldspar \pm (biotite) replaced by (chlorite)

None

Chlorite $\pm($ K-feldspar $)+($ albite $)$

$\mathrm{K}$-feldspar + epidote $+($ biotite $)+($ magnetite $) \pm($ chlorite $)$

$\mathrm{K}$-feldspar + epidote $+($ biotite $) \pm($ chlorite $)$

K-feldspar + epidote + (chlorite)

Chlorite + pyrite + chalcopyrite + (magnetite)

K-feldspar

K-feldspar \pm (Albite)

Scapolite + K-feldspar + albite

Sericite

None

None

Hematite \pm K-feldspar \pm albite

Reference: Stanley and others (1995) 
Table 4. Alteration-mineral assemblages in the Copper Mountain (British Columbia, Canada) and El Teniente (Chile) porphyry copper deposits.-Continued

\begin{tabular}{|c|c|}
\hline Pervasive style & Minerals \\
\hline \multicolumn{2}{|l|}{ EI Teniente, Chile } \\
\hline \multicolumn{2}{|l|}{ Vein style } \\
\hline Magnetite veins & Magnetite + quartz + anhydrite + actinolite + calcic plagioclase + (epidote) \\
\hline Quartz veins & Quartz + tourmaline + sericite + chlorite + magnetite \\
\hline $\begin{array}{l}\text { Quartz-anhydrite-K- } \\
\text { feldspar veins }\end{array}$ & \pm Na-K-feldspar \\
\hline $\begin{array}{l}\text { Quartz-chlorite- } \\
\text { (anhydrite-biotite-Na- } \\
\text { K-feldspar) veins }\end{array}$ & \pm Na-K-feldspar \\
\hline $\begin{array}{l}\text { Quartz-(anhydrite- } \\
\text { sulfide) } \pm \text { (K-feldspar- } \\
\text { chlorite-biotite) veins }\end{array}$ & $\pm \mathrm{Na}$-K-feldspar \\
\hline $\begin{array}{l}\text { Anhydrite-quartz- } \\
\text { (sulfide) breccias }\end{array}$ & $\pm \mathrm{Na}-\mathrm{K}$-feldspar \\
\hline $\begin{array}{l}\text { Quartz-sulfide- } \\
\text { (anhydrite) veins }\end{array}$ & \pm Biotite + (sericite) \\
\hline $\begin{array}{l}\text { Biotite-tourmaline- } \\
\text { quartz-anhydrite- } \\
\text { sulfide breccias }\end{array}$ & Chlorite + (sericite $)$ \\
\hline $\begin{array}{l}\text { Sulfide-chlorite- } \\
\text { (anhydrite-quartz) } \\
\text { breccias }\end{array}$ & Biotite \\
\hline $\begin{array}{l}\text { Quartz-anhydrite- } \\
\text { sulfide veins }\end{array}$ & Sericite + chlorite + quartz \\
\hline $\begin{array}{l}\text { Quartz-anhydrite- } \\
\text { tourmaline-sulfide- } \\
\text { gypsum-carbonate } \\
\text { veins }\end{array}$ & Quartz + sericite + chlorite \pm tourmaline \\
\hline
\end{tabular}


